\title{
ACTIVITIES OF THE WATER RESOURCES DIVISION, CALIFORNIA DISTRICT, FISCAL YEARS 1988-90
}

Compiled by D.A. Grillo, Myrna L. DeBortoli and Arlyn Lee

U.S. GEOLOGICAL SURVEY

Open-File Report 91-243

8
8
8 


\section{U.S. DEPARTMENT OF THE INTERIOR \\ MANUEL LUJAN, JR., Secretary}

U.S. GEOLOGICAL SURVEY

Dallas L. Peck, Director

Any use of trade, product, or firm names in this publication is for descriptive purposes only and does not imply endorsement by the U.S. Government.

For sale by:

Books and Open-File Reports Section

U.S. Geological Survey

Federal Center, Box 25425

Denver, CO 80225

For additional information write to:

District Chief

U.S. Geological Survey

Federal Building, Rm W-2234

2800 Cottage Way

Sacramento, CA 95825 


\section{MESSAGE FROM THE DISTRICT CHIEF}

After almost a century of activity and publication of more than 2,200 water-resources related reports for the State of California, one needs to ask: have we as an agency improved the level of understanding of the hydrologic environment in the State? Have we provided sufficient data and interpretive products that are necessary for sound decisionmaking to the water-management community?

A century of existence certainly demonstrates an historical role for the U.S. Geological Survey in the hydrologic community. The resulting 2,200 reports continue to serve as the foundation of hydrologic knowledge for the State of California. Additionally, hydrologic historians will note: (1) the evolution and sophistication of the investigative and interpretive tools used to collect and transfer hydrologic data knowledge to the water user community, and (2) a strong and steadfast nonregulatory stance in the midst of highly controversial and political issues. The justification for this stance is simple--the need has existed and will continue to exist for an unbiased entity such as the U.S. Geological Survey to produce scientific, credible information.

The major national water issues for the Water Resources Division during fiscal years $1988-90$ correspond well to water issues in the State of California. These issues are (1) water availability and competition for this water; (2) quality of water; and (3) management of water and land resources. Studies being conducted by the U.S. Geological Survey and described in this publication are, for the most part, in support of providing data and interpretation to address these issues.

As an agency, we are aware of and dedicated to the premise that credible data are obtained only when subjected to consistent, discipline related, quality-assurance programs. Throughout the Water Resources Division, continuous quality-assurance programs are conducted of all the activities that influence and ensure the quality of our products and services. These documented and proven quality-assurance programs provide to the hydrologic community necessary confidence that our products and services will meet the most stringent criteria.

Numerous relevant and complex studies are being conducted by the California District. Several such examples are the continued documentation of the hydrodynamics and controlling factors in San Francisco Bay; the fate and distribution of toxic contaminants in the San Francisco Bay-Estuary system; examination of the relation between ground-water withdrawals and fissuring on Rogers Lake playa surface, Edwards Air Force Base; a redefinition of the geohydrology and optimization of ground-water development and recharge in the Oxnard Plain; factors controlling the transformation and movement of nitrogen through the unsaturated zone; and the variability of hydrologic impacts of storms moving across the Sierra Nevada and the implications of climate change. These studies and the others described herein are providing valuable data and methods development that continue to contribute significantly to the science of hydrology and the water-management community within the State.

John M. Klein

District Chief

U.S. Geological Survey

Sacramento, California 


\section{CONTENTS}

U.S. Geological Survey origin 1

Water Resources Division basic mission and program 2

California District organization 2

Califormia District addresses 4

California District funding 6

Water conditions 10

Project descriptions:

CA001 Surface-water stations $\mathbf{1 6}$

CA002 Ground-water stations $\mathbf{1 8}$

CA003 Water-quality stations $\mathbf{2 0}$

CA004 Sediment stations 22

CA005 National trends network for monitoring atmospheric deposition 23

CA007 Water-use information for California $\mathbf{2 4}$

CA027 Ground-water appraisal, U.S. Marine Corps Base, Twentynine Palms 26

CA030 Appraisal of ground-water resources, Indian Wells Valley 28

CA271 Characteristics of flooding and channel changes of the Sacramento River between Hamilton City and Butte City $\mathbf{3 0}$

CA342 Ground-water resources of the Santa Barbara area 31

CA382 Development of a moving-boat discharge-measuring system using an acoustic Doppler current profiler $\mathbf{3 3}$

CA387 Geohydrologic study of Coachella Valley 35

CA397 Reappraisal of the ground-water budget at Honey Lake Valley, Washoe County, Nevada, and Lassen County, California 37

CA399 Reclaimed water use, San Diego County 39

CA400 Transport of contaminants from underground wastewater disposal systems, upper Mojave River basin 41

CA419 Estimating tidal and residual circulation in San Francisco Bay 43

CA424 Southern California Regional Aquifer-System Analysis 46

CA428 Central Valley Regional Aquifer-System Analysis 48

CA429 Saltwater intrusion at Santa Barbara $\mathbf{5 2}$

CA431 Hydrologic studies related to volcanic activity in Long Valley 54

CA453 Irrigation drainage field-screening study of Sacramento Refuge complex 56

CA456 Western San Joaquin Valley hydrologic studies $\mathbf{5 7}$

CA459 Investigation of land subsidence, Sacramento Valley; application of a new technique for investigation of land subsidence 61

CA460 Irrigation drainage field-screening study of Klamath Basin Refuge complex 63

CA461 Geohydrologic investigation of the Sacramento Valley area 64

CA465 Effects of urban stormwater runoff on the San Joaquin River near Fresno 66

CA466 Evaluation of ground-water contamination from nonpoint sources using solute-transport techniques 68

CA467 Optimum management in a basin with changing water-supply and water-quality problems $\mathbf{7 0}$

CA468 Water resources of the Cambria-San Simeon area, San Luis Obispo County $\mathbf{7 2}$

CA469 Rainfall and runoff in the Antelope Valley drainage area 74

CA470 Detailed study and assessment of irrigation drainage in the Salton Sea area, Imperial Valley $\mathbf{7 6}$ 
Project descriptions--Continued

CA472 Changes in runoff in Perris Valley, Riverside County 78

CA473 Water resources and geohydrology of the city and county of San Francisco 79

CA474 Ground-water hydraulics in Wolf Valley, Riverside County $\mathbf{8 1}$

CA475 Effects of nonpoint source runoff from Alameda County on South San Francisco Bay $\mathbf{8 3}$

CA476 Development of Sacramento River bed-scour relation at the SR-32 bridge at Hamilton City $\mathbf{8 5}$

CA477 Ground-water resource investigations, Edwards Air Force Base 87

CA479 Evaluation of subsidence rates and processes in surficial peat, Sacramento-San Joaquin Delta 89

CA480 Nitrate in the Hemet ground-water subbasin 91

CA481 Processes governing the distribution and mobility of selenium and arsenic in shallow ground water, Tulare basin 93

CA482 Interaction of ground-water flow at regional, subregional and farm scales, and implications for drain-water flow and quality, western San Joaquin Valley 94

CA483 Optimum control of seawater intrusion, Oxnard Plain, Ventura County 96

CA484 San Francisco Bay-Estuary toxic contaminant study 97

CA487 Water resources of Indian reservations in California 98

CA488 Assessment of the effects of potential climate change on the water resources of the Carson, American, and Truckee River basins 99

Bibliography 102

CA490 Characterization of the quality of water resources of Santa Clara County $\mathbf{1 0 0}$

Sources of WRD publications and information 115

Where to obtain additional information on U.S. Geological Survey programs 116

Where to obtain additional information on U.S. Geological Survey reports 116

\section{FIGURES}

1. Organization chart for the California District, $1990 \quad 3$

2. Map showing location of offices in the California District 5

3,4. Diagrams showing:

3. Sources of Califormia District funds in fiscal years $1988-90 \quad 8$

4. Categories of investigations in the California District, by funding, fiscal years 1988-90 9

5,6. Graphs showing

5. Annual departure from average runoff in the Sacramento River basin $\mathbf{1 1}$

6. Annual departure from average runoff at six unregulated long-term streamflow stations selected to represent statewide conditions 13

TABLE

1. Summary of water conditions in California, $1987-90$ 


\section{U.S. GEOLOGICAL SURVEY ORIGIN}

The U.S. Geological Survey (USGS) was established by an act of Congress on March 3, 1879, to provide a permanent Federal Agency to conduct the systematic and scientific "classification of the public lands, and examination of the geological structure, mineral resources, and products of national domain." An integral part of that original mission includes publishing and disseminating the earth-science information needed to understand, to plan the use of, and to manage the Nation's energy, land, mineral, and water resources.

Since 1879 , the research and factfinding role of the USGS has grown and been modified to meet the changing needs of the Nation it serves. As part of that evolution, the USGS has become the Federal Government's largest earth-science research agency, the Nation's largest civilian mapmaking agency, the primary source of data on the Nation's surface- and ground-water resources, and the employer of the largest number of professional earth scientists. Today's programs serve a diversity of needs and users. Programs include:

- Conducting detailed assessments of the energy and mineral potential of the Nation's land and offshore areas.

- Investigating and issuing warnings of earthquakes, volcanic eruptions, landslides, and other geologic and hydrologic hazards.

- Conducting research on the geologic structure of the Nation.

- Studying the geologic features, structure, processes, and history of the other planets of our solar system.

- Conducting topographic surveys of the Nation and preparing topographic and thematic maps and related cartographic products.

- Developing and producing digital cartographic data bases and products.

- Collecting data on a routine basis to determine the quantity, quality, and use of surface and ground water.

- Conducting water-resource appraisals in order to describe the consequences of alternative plans for developing land and water resources.

- Conducting research in hydraulics and hydrology and coordinating all Federal water-data acquisition.

- Using remotely sensed data to develop new cartographic, geologic, and hydrologic research techniques for natural-resources planning and management.

- Providing earth-science information through an extensive publications program and a network of public-access points.

Along with its continuing commitment to meet the growing and changing earth-science needs of the Nation, the USGS remains dedicated to its original mission to collect, analyze, interpret, publish, and disseminate information about the natural resources of the Nation--providing "Earth science in the public service." 


\section{WATER RESOURCES DIVISION BASIC MISSION AND PROGRAM}

The mission of the Water Resources Division (WRD) is to provide the hydrologic information and understanding needed for the optimum utilization and management of the Nation's water resources for the overall benefit of the people of the United States. To accomplish this mission, the WRD, in cooperation with local, State, and Federal agencies, uses a wide variety of investigative and interpretive techniques to collect and transfer hydrologic information to the water-user community. An integral part of that mission includes publishing and disseminating the earth-science information needed to understand, to plan the use of, and to manage the Nation's energy, land, mineral, and water resources.

This is accomplished, in large part, through cooperation with other Federal and non-Federal agencies, by:

- Collecting, on a systematic basis, data needed for the continuing determination and evaluation of the quantity, quality, and use of the Nation's water resources.

- Conducting analytical and interpretive water-resources appraisals describing the occurrence, availability, and physical, chemical, and biological characteristics of surface and ground water.

- Conducting supportive basic and problem-oriented research in hydraulics, hydrology, and related fields of science to improve the scientific basis for investigations and measurement techniques and to understand hydrologic systems sufficiently well to quantitatively predict their response to stress, either natural or manmade.

- Disseminating the water data and the results of these investigations and research through reports, maps, computerized information services, and other forms of public releases.

- Coordinating the activities of Federal agencies in the acquisition of water data for streams, lakes, reservoirs, estuaries, and ground water.

- Providing scientific and technical assistance in hydrology fields to other Federal, State, and local agencies, to licensees of the Federal Energy Regulatory Commission, and to International agencies on behalf of the Department of State.

\section{CALIFORNIA DISTRICT ORGANIZATION}

The headquarters for the California District is in Sacramento. Hydrologic investigations and data collection are conducted from 2 project offices and 10 field offices. These offices and supporting units of the District are shown in the organization chart (fig. 1). 


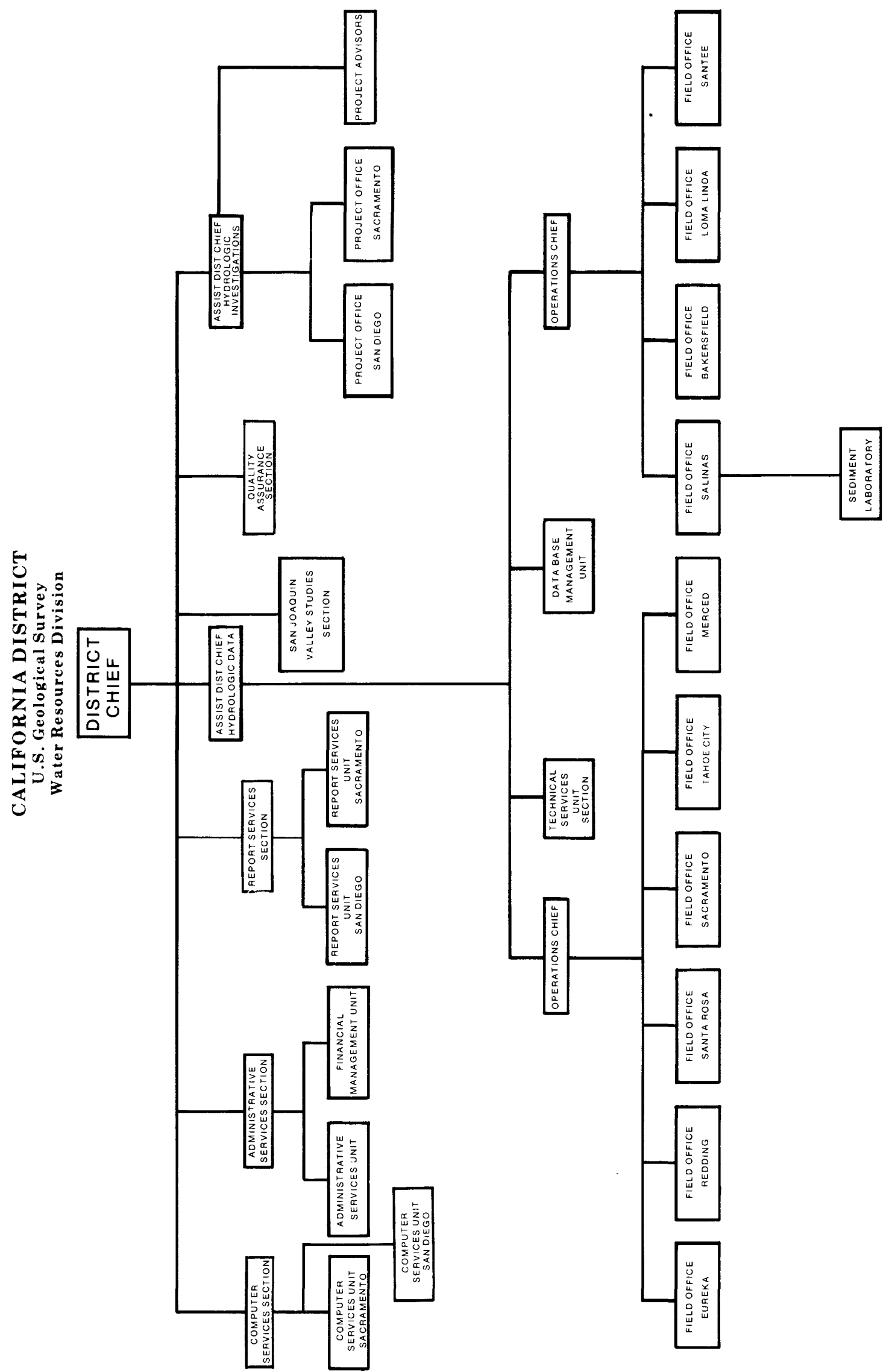

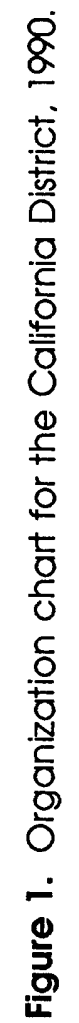




\section{CALIFORNIA DISTRICT ADDRESSES}

Inquiries regarding projects described in this report may be directed to the District Office. Addresses for the District Office and project and field offices are listed below. Location of offices are shown in figure 2.

DISTRICT OFFICE

PROJECT OFFICES

Sacramento

San Diego

FIELD OFFICES

Bakersfield

Eureka

Loma Linda

Merced

Redding

Sacramento

Salinas

Santa Rosa

Santee

Tahoe City
(805) $861-4347$

(916) 978-4633

(916) $978-4648$

(619) $557-6700$

(707) 443-2028

(714) $383-5617$

(209) 383-9067

(916) 246-5282

(916) $978-4658$

(408) 754-6717

(707) $576-1740$

(714) $557-5155$

(916) 583-4823
U.S. Geological Survey

2800 Cottage Way, Rm. W-2234

Sacramento, CA 95825

2800 Cottage Way, Rm. W-2234

Sacramento, CA 95825

5735 Kearny Villa Road, Suite O

San Diego, CA 92123

3131 Pegasus Drive

Bakersfield, CA 93308

1105 6th Street

Eureka, CA 95501

10421 Corporate Drive, Suite A Redlands, CA 92374

1547 Yosemite Parkway Merced, CA 95340

11075 Black Marble Way Redding, CA 96003

2800 Cottage Way, Rm. W-2234

Sacramento, CA 95825

P.O. Box 5027

Salinas, CA 93915

5 West 9th Street, \#2

Santa Rosa, CA 94502

10130 Mission Gorge Road

Santee, CA 92702

605 Westlake Boulevard

Tahoe City, CA 95730 


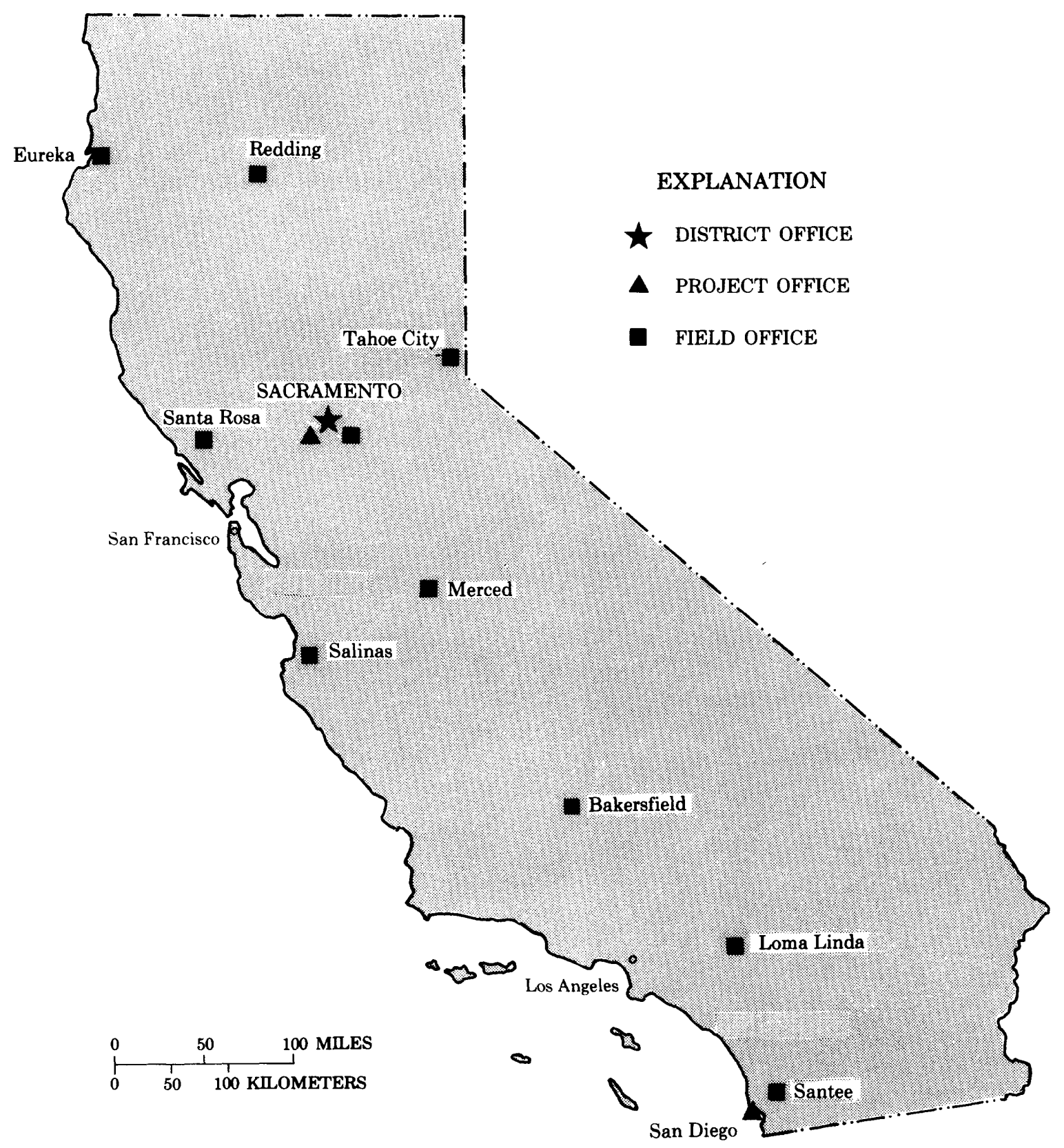

Figure 2. Location of offices in the California District. 


\section{CALIFORNIA DISTRICT FUNDING}

Programs of the Water Resources Division in California are funded as follows: (1) the Federal program, which is specifically identified in annual Geological Survey appropriations made by Congress; (2) the Federal-State cooperative program, where the Water Resources Division represents National interest, the cooperating agencies represent State and local interest, and the funding generally is shared equally (the Federal share comes from direct Congressional appropriations); (3) the Other-Federal-Agencies (OFA) Program, which is funded by the Federal agencies that request the work. Total funds and sources of funding for fiscal years 1988, 1989, and 1990, are shown in figure 3. [The fiscal year (FY) is from October 1 to September 30, and is designated by the calendar year in which it ends.]

The percentage of investigations, by funding, for fiscal years 1988, 1989, and 1990 in each of the broad categories of hydrologic-data collection, areal appraisals and interpretive studies, and research projects are shown in figure 4.

In fiscal years 1988-90, State, local, and Federal agencies contributed funds and (or) services in cooperative programs with the California District. Organizations that assisted the Survey through cooperative agreement are:

\section{$\underline{\text { State Agencies }}$}

California Department of Boating and Waterways

California Department of Parks and Recreation

California Department of Transportation

California Department of Water Resources

California State Water Resources Control Board

Califomia Regional Water Quality Control Board

Colorado River Basin Region

Lahontan Region

San Diego Region

San Francisco State University

\section{$\underline{\text { Local Agencies }}$}

Alameda County Flood Control and Water Conservation District

Alameda County Water District

Antelope Valley-East Kern Water Agency

Calaveras County Water District

Carpenteria County Water District

Casitas Municipal Water District

Coachella Valley Water District

Contra Costa County Flood Control and Water Conservation District

Crestline-Lake Arrowhead Water Agency

Desert Water Agency

East Bay Municipal Utility District

Eastern Municipal Water District

East Valley Water District

Fox Canyon Groundwater Management Agency

Fresno Metropolitan Flood Control District

Georgetown Divide Public Utility District

Goleta Water District
Local Agencies--Continued

Humboldt Bay Municipal Water District

Imperial County Department of Public Works

Imperial Irrigation District

Indian Wells Valley Water District

Inyo County, Department of Water

Lompoc, city of

Los Angeles, city of, Department of Water and Power

Los Angeles County Department of Public Works

Madera Irrigation District

Marin Municipal Water District

Mendocino County Water Agency

Merced, city of

Merced Irrigation District

Modesto Irrigation District

Mojave Water Agency

Mono County

Montecito Water District

Monterey County Flood Control and Water Conservation District

Monterey Peninsula Water Management District

Nevada Irrigation District

Oakdale-South San Joaquin Irrigation District

Orange County Environmental Management Agency

Orange County Water District

Oroville-Wyandotte Irrigation District

Pacific Gas \& Electric Company

Pacific Power and Light Company

Pala Band of Mission Indians

Palo Alto, city of

Panoche Water and Drainage District

Pechanga Indian Reservation

Placer County Water Agency 
Local Agencies--Continued

Rancho California Water District

Riverside County Flood Control and Water

Conservation District

Rock Creek Limited Partnership

Sacramento Municipal Utility District

Sacramento County Regional Sanitation District

San Benito County Water Conservation and

Flood Control District

San Bernardino County Flood Control District

San Bernardino Valley Municipal Water District

San Diego, city of

San Diego County Department of Planning and

\section{Land Use}

San Diego County Department of Public Works

San Francisco, City and County, Hetch-Hetchy Water and Power

San Francisco Water Department

San Luis Obispo County Engineering Department

San Mateo County

Santa Barbara, city of

Santa Barbara County Flood Control and Water Conservation District

Santa Barbara County Water Agency

Santa Clara Valley Water District

Santa Cruz, city of

Santa Cruz County Flood Control and Water Conservation District

Santa Maria Valley Water Conservation District

Santa Ynez River Water Conservation District

Scotts Valley Water District

Sonoma County Planning Department

Sonoma County Water Agency

Southern California Edison Company

Tahoe Regional Planning Agency

Terra Bella Irrigation District

Tulare County Flood Control District

Tuolumne County

Turlock Irrigation District

United Water Conservation District
Local Agencies--Continued

Ventura County Public Works Agency

Western Municipal Water District

Woodbridge Irrigation District

Yolo County Flood Control and Water Conservation District

Yuba County Water Agency

\section{Federal Agencies}

U.S. Department of Agriculture Forest Service

U.S. Department of the Air Force Edwards Air Force Base Vandenberg Air Force Base

U.S. Department of the Army Corps of Engineers Los Angeles District Sacramento District San Francisco District

U.S. Department of the Interior Bureau of Indian Affairs Bureau of Land Management Bureau of Reclamation Fish and Wildlife Service National Park Service

U.S. Department of Justice U.S. Penitentiary, Lompoc

\section{U.S. Navy}

Marine Corps Air Ground Combat Center, Twentynine Palms

Marine Corps Base, Camp Pendleton

Naval Air Station, Point Magu

Naval Weapons Center, China Lake 


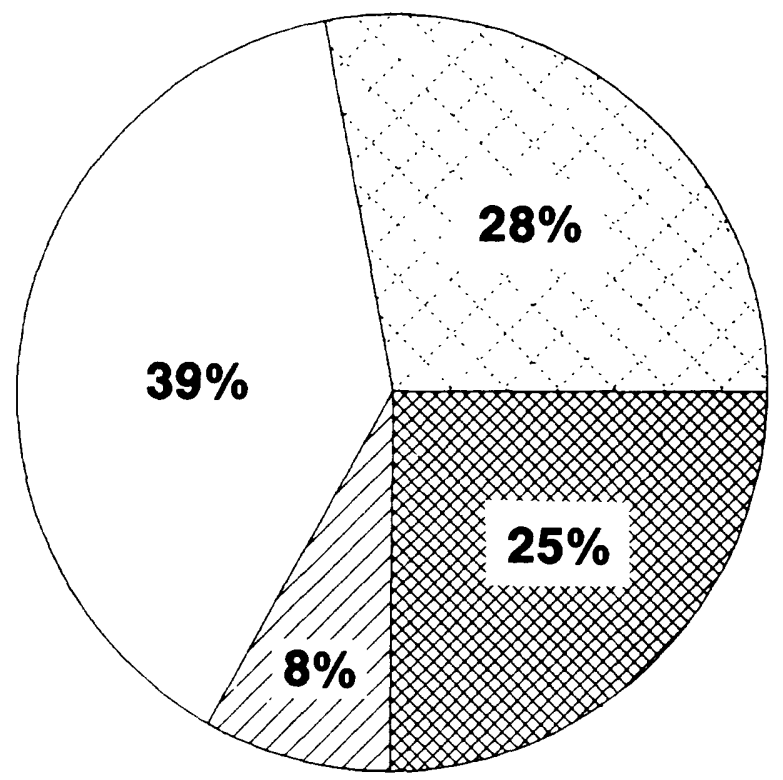

FY 1988

TOTAL $\$ 13,942,924$

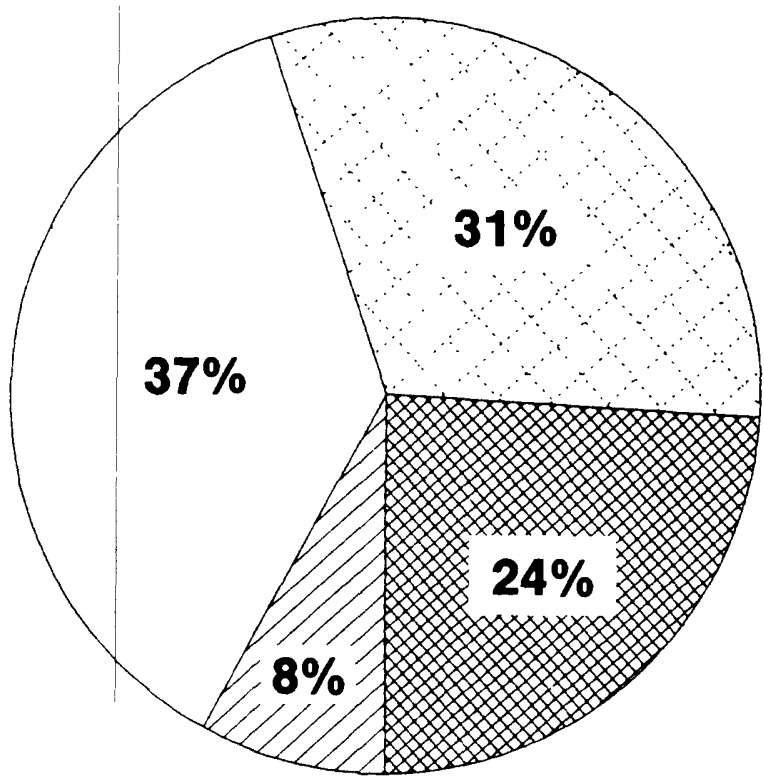

FY 1989

TOTAL $\$ 14,212,003$

State and Local Funds

Federal-State Cooperative Program

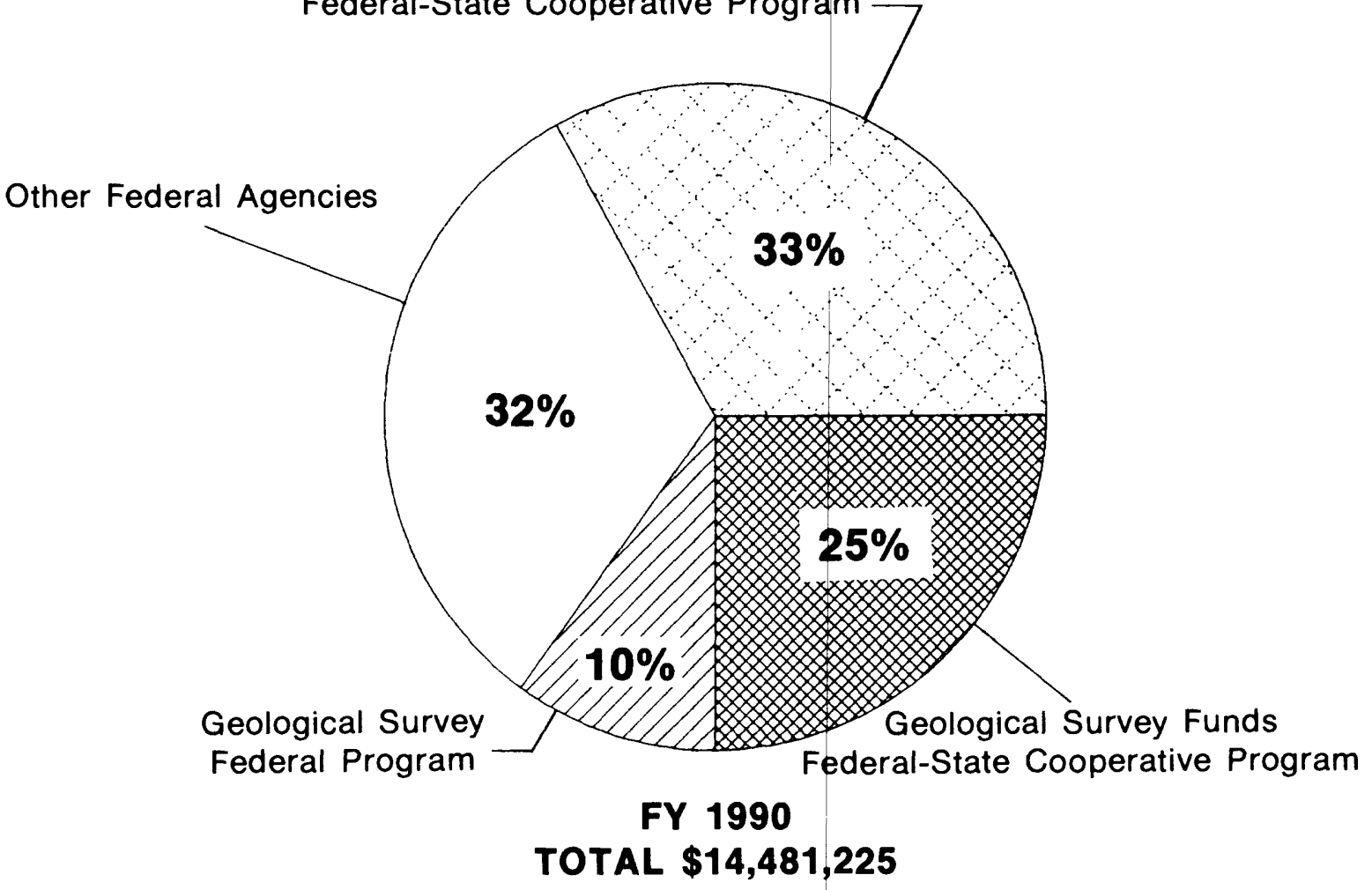

Figure 3. Sources of California District funds in fiscal years 1988-90. 


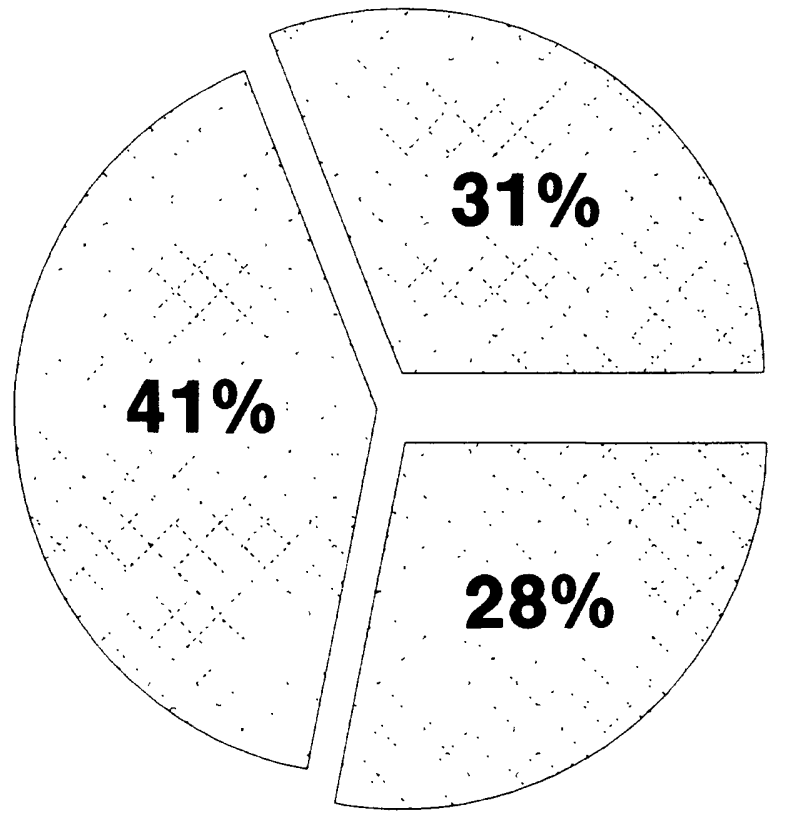

FY 1988

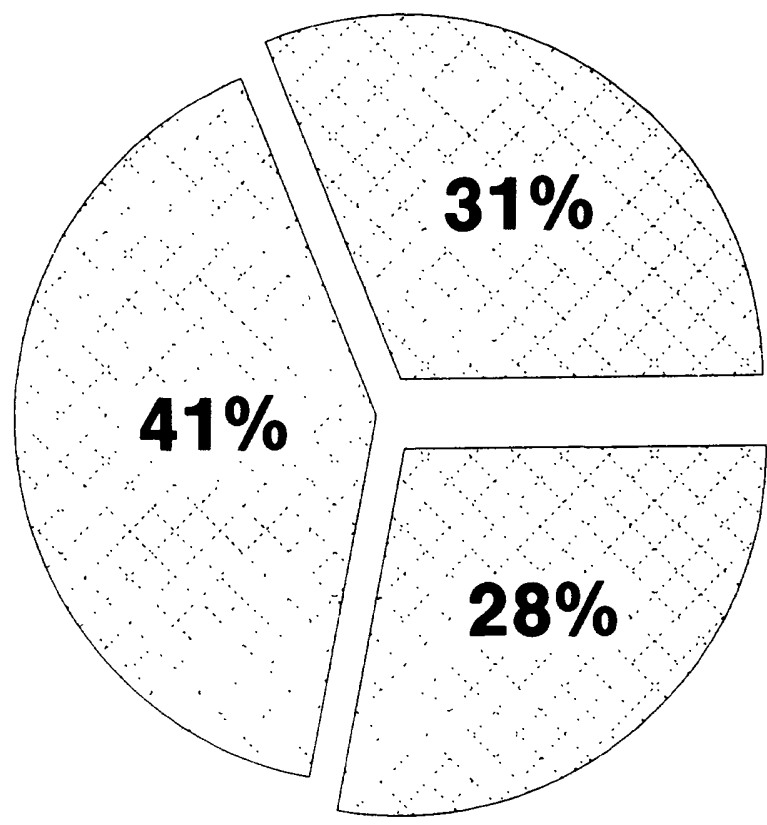

FY 1989

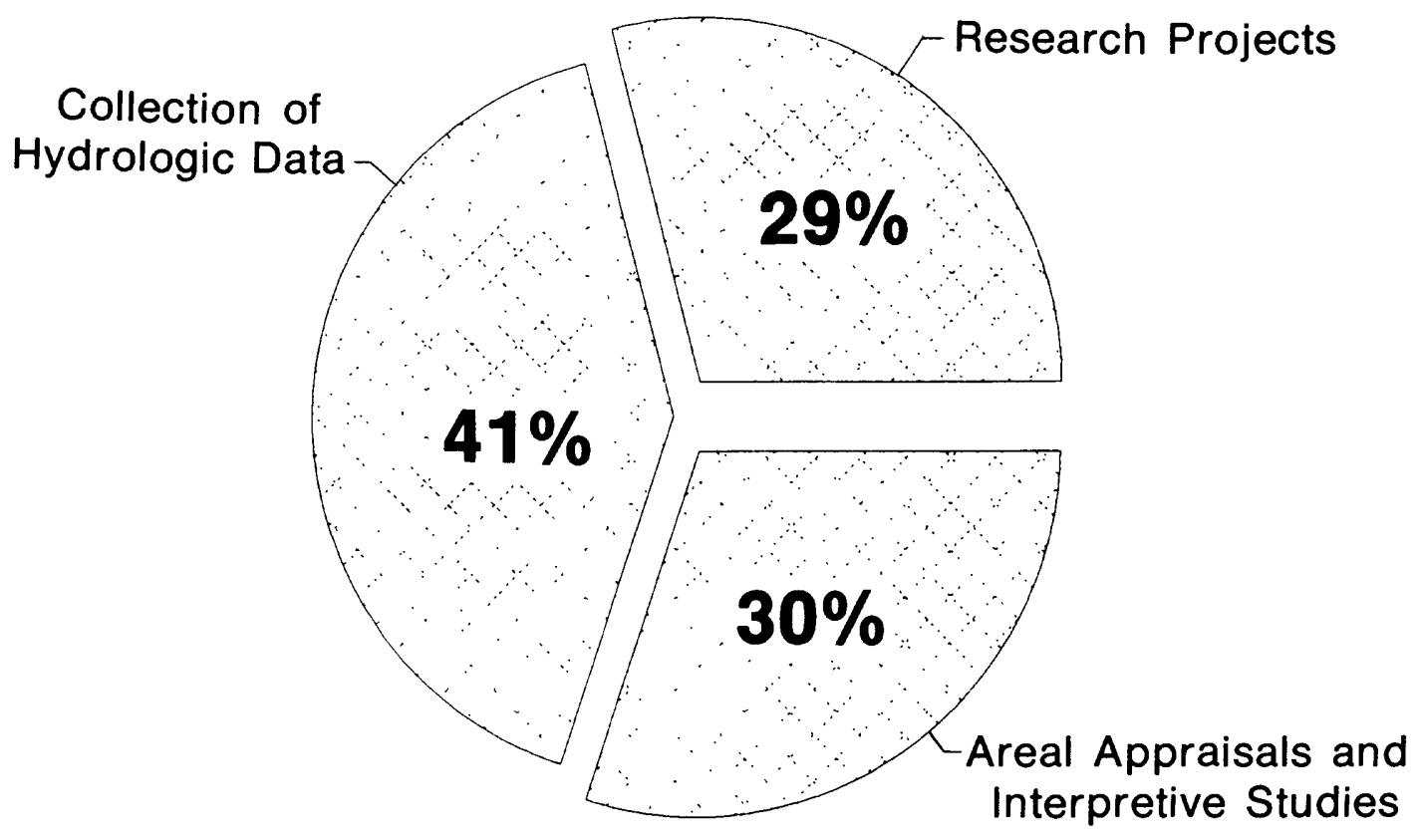

FY 1990

Figure 4. Categories of investigations in the California District, by funding, fiscal years 1988-90. 


\section{WATER CONDITIONS}

California experienced its fourth consecutive year of drought in 1990. Statewide precipitation, runoff, and reservoir storage were below average during each of the water years 1987-90. Table 1 shows the percentage of average runoff by hydrologic region for each year of the drought and reservoir storage at the end of water year 1990.

Stream runoff in the Sacramento River basin (fig. 5) is a major source of water for State and Federal water-supply projects and is an indicator of the State's water supply. On the basis of runoff in the Sacramento River basin, the California Department of Water Resources classified water years 1987, 1988, and 1990 as "critically dry." A critically dry year is the driest category and occurs on the average of about 1 out of 10 years during the period of record shown in figure 5. Plentiful rain and snow over the northern half of the State in March 1989 significantly maderated the severity of the drought in the Sacramento River basin. As a result, water year 1989 was not classified as a critically dry year even though runoff was below average.

Two consecutive critically dry years in the Sacramento River basin (as in 1987-88) have occurred only twice before in this century--1933-34 and 1976-77. Three consecutive critically dry years would have been unprecedented in the historical record. Three critically dry years during a 4-year period (such as the current 4-year drought) have occurred only once before--1931-34. The drought of 1987-90 ranks as the second driest 4-year period in the 119 years of runoff record for the Sacramento River basin, indicating a recurrence interval of almost 60 years.

Table 1. Summary of water conditions in California, 1987-90

[From California Department of Water Resourcès summaries]

\begin{tabular}{|c|c|c|c|c|c|}
\hline \multirow{3}{*}{$\begin{array}{l}\text { Hydrologic } \\
\text { region }\end{array}$} & \multicolumn{5}{|c|}{ Percent of average } \\
\hline & \multicolumn{4}{|c|}{ Runoff (water years) } & \multirow{2}{*}{$\begin{array}{l}\text { Reservoir } \\
\text { storage } \\
\text { Oct. } 1,1990\end{array}$} \\
\hline & 1987 & 1988 & 1989 & 1990 & \\
\hline North Coast & 56 & 52 & 76 & 46 & 72 \\
\hline San Francisco Bay & 25 & 26 & 45 & 23 & 78 \\
\hline Central Coast ... & 19 & 20 & 19 & 9 & 17 \\
\hline South Coast $\ldots$ & 32 & 40 & 28 & 16 & 107 \\
\hline Sacramento Basin & 49 & 49 & 78 & 49 & 64 \\
\hline San Joaquin Basin & 33 & 38 & 60 & 40 & 52 \\
\hline Tulare Lake Basin & 45 & 42 & 50 & 34 & 24 \\
\hline North Lahontan & 40 & 33 & 78 & 45 & 18 \\
\hline South Lahontan .. & 70 & 62 & 64 & 54 & 69 \\
\hline Colorado River ${ }^{1}$ & 93 & 58 & 41 & 39 & -- \\
\hline STATEWIDE & 48 & 48 & 70 & 45 & 60 \\
\hline
\end{tabular}




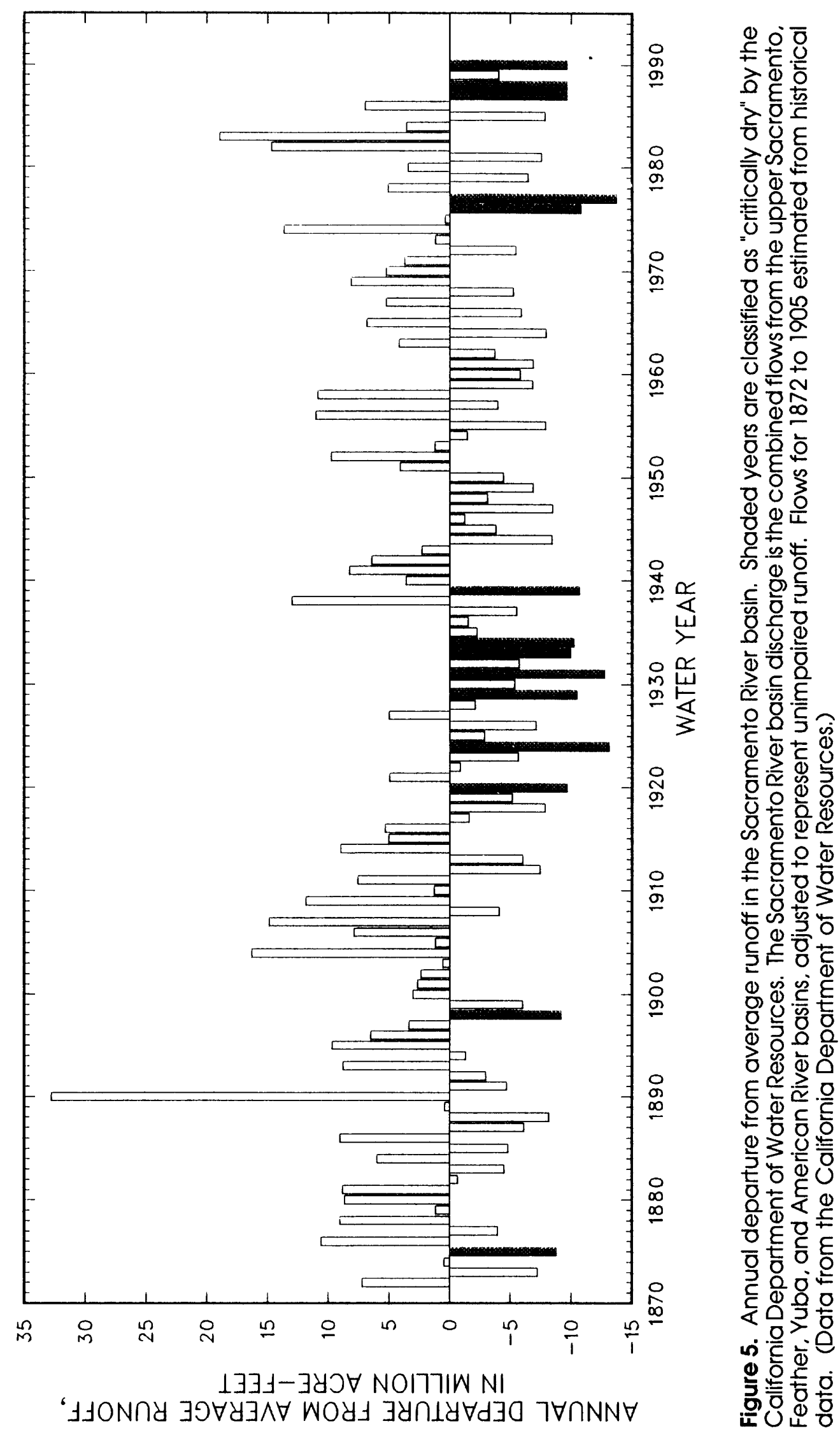


Streamflow records from six unregulated long-term gaging stations indicate the severity and areal extent of the current drought (fig. 6). The records show that water years 1987-90, when considered individually, do not rank among the driest years of record at any of the stations; however, when the 4-year period is considered as a whole, the drought of 1987-90 ranks among the most severe 4-year droughts in the State's history. Along the central coast and in the central Sierra Nevada (stations 11152000 and 11264500), the current drought is the driest 4-year period on record, with a recurrence interval (limited by the length of record at the stations) of about 80 years. In the northern part of the State (stations 11383500 and 11522500) and in the southern Sierra Nevada (station 11186000), the current drought ranks second in severity behind a 4-year period during the drought of 1928-37, with a recurrence interval of about 35 years. In southern California (station 11098000), the current drought actually began in 1984 and ranks third in severity behind 7-year periods in 1928-34 and 1959-65, with a recurrence interval of about 25 years.

A comparison of the relative severity of the 4-year drought in 1987-90 with that of the 2-year drought in 1976-77 provides additional perspective. Although the current drought is twice as long, runoff deficiencies (departures below average) for the entire 4 years of the current drought are only about 1.3 times those that occurred in 1976-77. Exceptions are southern California, where the 1976-77 drought was not particularly severe and the central coast, where the current drought is the most severe. Runoff deficiencies in the central coast were 1.7 times those of the 1976-77 drought.

Although water year 1987 marks the beginning of the current period of drought, water supply shortages were minimal in 1987 as a result of carryover surface-water storage from 1986 . The most serious effects in 1987 were on wild lands and nonirrigated agriculture. During water year 1988 and continuing into the first half of water year 1989, water shortages affected about one-third of California's population and more than 40 percent of the State's irrigated agriculture. Many areas had insufficient rainfall for dry-farmed crops, and ranchers from 42 counties were accepted into Federal emergency feed programs. Fourteen counties declared drought emergencies. Many urban areas instituted mandatory or voluntary water-conservation measures. Where available, ground water was used to supplement surfacewater supplies. In general, ground-water supplies were considered adequate, but shortages did occur in areas where the ground-water reservoirs are small (upland and coastal areas) and in localized areas of excessive drawdown (such as the Santa Clara Valley).

In water year 1989, both of the State's two major water projects, the State Water Project and the Federal Central Valley Project, announced anticipated reductions in water deliveries of as much as 50 percent; however, the wet weather in March 1989 allowed full delivery of agricultural water supplies and the eventual lifting of drought restrictions in most areas of the State. Water restrictions continued along the central coast, which did not benefit from the March 1989 rains and does not receive water from any of the State's big water projects.

In water year 1990, spring rains did not bring any drought relief. Deliveries of State and Federal project water were reduced by as much as 50 percent for agricultural customers; reductions to some municipal and industrial contractors were less. This is only the second time in the history of the water projects that such reductions were necessary; the first was in 1977. Deliveries of surface water from other sources were greatly curtailed as well. Most urban areas of the State again instituted drought restrictions. The areas most affected by the drought were those without access to large-scale developed surface-water supplies or a major ground-water basin. Santa Barbara, probably the most adversely affected community in the State, enacted a strict mandatory water-conservation program in an attempt to reduce water use by 45 percent.

As the drought continues, carryover storage in reservoirs into water year 1991 is well below average. Ground-water reserves continue to be used, which can cause excessive drawdown, water-quality deterioration, seawater intrusion into some coastal basins, and the potential for land subsidence and the associated reduction in storage due to compaction. Ground-water storage is reaching record lows in some areas. The drought has adversely affected fish and wildlife, wildland resources, water quality, hydroelectric power, and recreation. 


\section{MAJOR CALIFORNIA DROUGHTS}

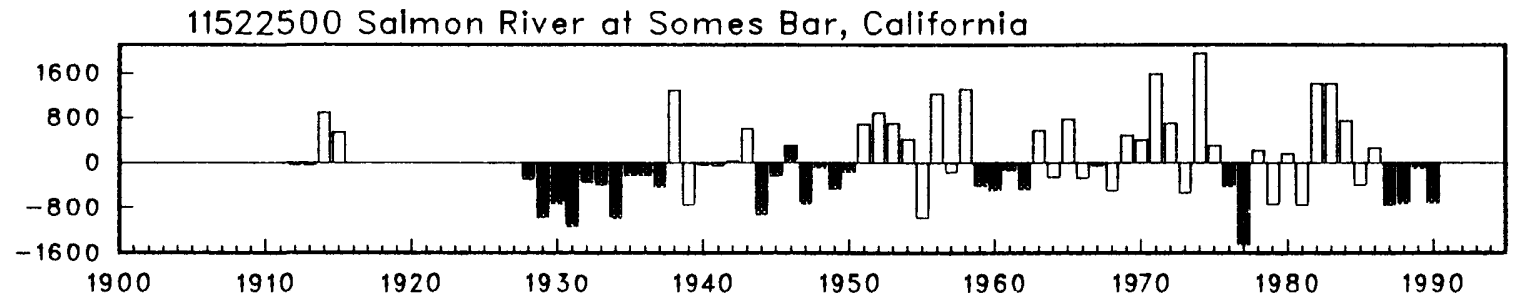

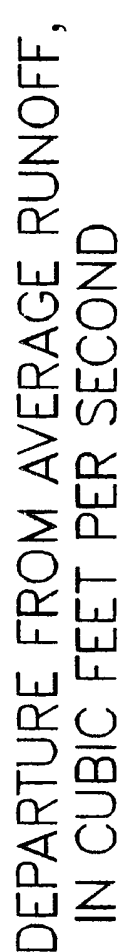

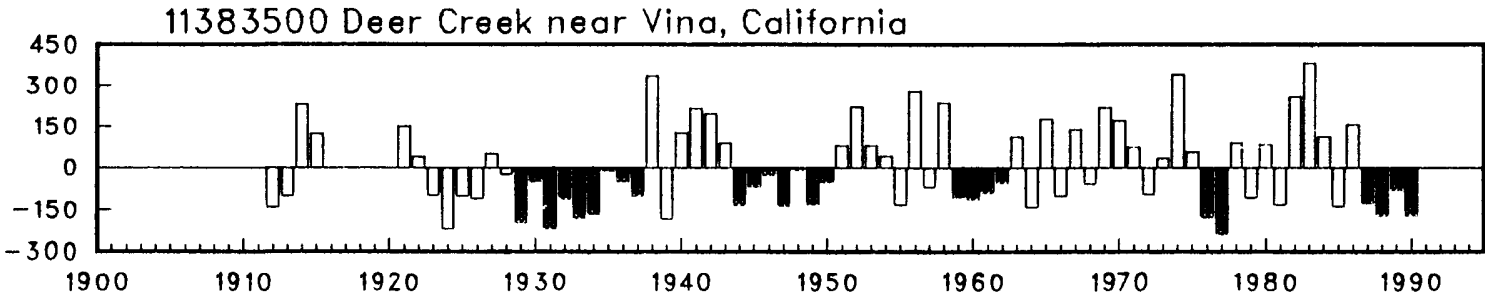

客
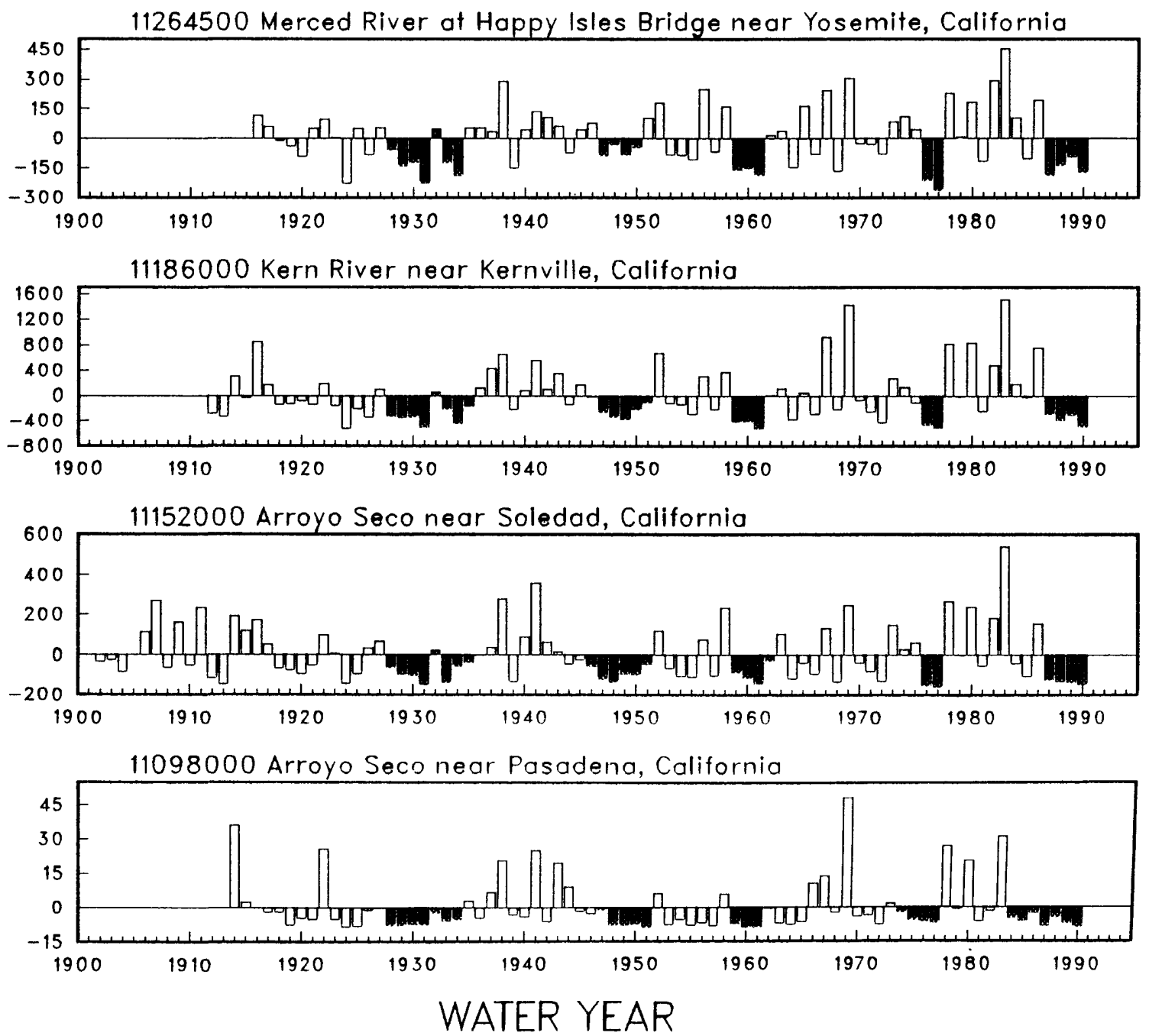

Figure 6. Annual departure from average runoff at six unregulated long-term streamflow stations selected to represent statewide conditions. 
PROJECT DESCRIPTIONS

PAGE 15 


\section{SURFACE-WATER STATIONS}

Number: CA001

Location: Statewide (See accompanying map)

Project Chief: Kenneth W. Lee

Period of Project: Continuing

Problem: Surface water accounts for about 60 percent of the freshwater withdrawals in California--more than 22.5 billion gallons per day in 1985. About 31 percent of the population, 8 million people, use surface water for domestic supplies. More than 20 billion gallons per day was withdrawn for irrigation in 1985. The distribution of surface water is highly variable both seasonally and areally; close monitoring of runoff is essential to the optimum management and development of this resource.

Objectives: Collect and publish surface-water data to meet needs for (1) assessing quantity and distribution of surface-water resources; (2) operating reservoirs for power, flood control, and irrigation; (3) flow forecasting; (4) monitoring of flow for instream-use requirements; (5) determining discharge to support water-quality sampling and assessment programs; (6) determining safe releases of treated reclaimed water to streams and rivers; (7) defining statistical streamflow characteristics needed for research and planning and design of dams, bridges, culverts, canals, flood-management projects, and ground-waterrecharge facilities.

Approach: Stage and discharge of streams and stage and contents of lakes and reservoirs will be measured and recorded. Standard methods of data collection will be used as described in the series "Techniques of Water-Resources Investigations of the U.S. Geological Survey." Partial-record data will be collected instead of continuous-record data where it serves the required purpose.

\section{Progress:}

FY1988: Surface-water data from 513 continuous streamflow stations were collected and compiled for publication. Records for 157 streamflow stations provided by other agencies and Federal Energy Regulatory Commission (FERC) licensees were reviewed for publication. Records from 54 reservoir sites were collected and compiled for publication and 74 reservoir records provided by cooperators were reviewed and published. Data on peak flow, low flow, seasonal flow, limited range of discharge, or stage information at 70 partial-record sites were collected and compiled for publication. An additional 212 records provided primarily by FERC licensees were reviewed but not published.

FY1989: Surface-water data from 568 continuous streamflow stations were collected and compiled for publication. Records for 189 streamflow stations provided by other agencies and FERC licensees were reviewed for publication. Records from 34 reservoir sites were collected and compiled for publication, and 70 reservoir records provided by cooperators were reviewed and published. An additional 52 reservoir records provided by cooperators were reviewed but not published. Data on peak flow, low flow, seasonal flow, limited range of discharge, or stage information at 96 partial-record sites were collected and compiled for publication. An additional 179 provided primarily by FERC licensees were reviewed but not published.

FY1990: Surface-water data from 766 continuous streamflow stations were collected and compiled for publication; about 200 of which were provided by other agencies and FERC licensees. Data from 164 reservoir sites were either collected or provided by cooperator for review. Data on peak flow, low flow, seasonal flow, limited range of discharge, or stage information at 116 partial-record stream and reservoir sites were collected and compiled for publication.

Plans for Next Year: Statewide data collection and review will continue. Thirty-seven stations are equipped with satellite-relay data in transmitters installed by the U.S. Geological Survey. Installation of additional satellite data-collection platforms is planned for real-time transmission of streamflow information from selected remote stations. 
Reports:

U.S. Geological Survey, 1988, Water resources data--California, water year 1986: U.S. Geological Survey Water-Data Reports CA-86-1 to CA-86-4.

U.S. Geological Survey, 1988, Water resources data--California, water year 1987: U.S. Geological Survey Water-Data Reports CA-87-1 to CA-87-4.

U.S. Geological Survey, 1989, Water resources data--California, water year 1988: U.S. Geological Survey Water-Data Reports CA-88-1 to CA-88-4.

U.S. Geological Survey, 1990, Water resources data--California, water year 1989: U.S. Geological Survey

Water-Data Reports CA-89-1 to CA-89-4.

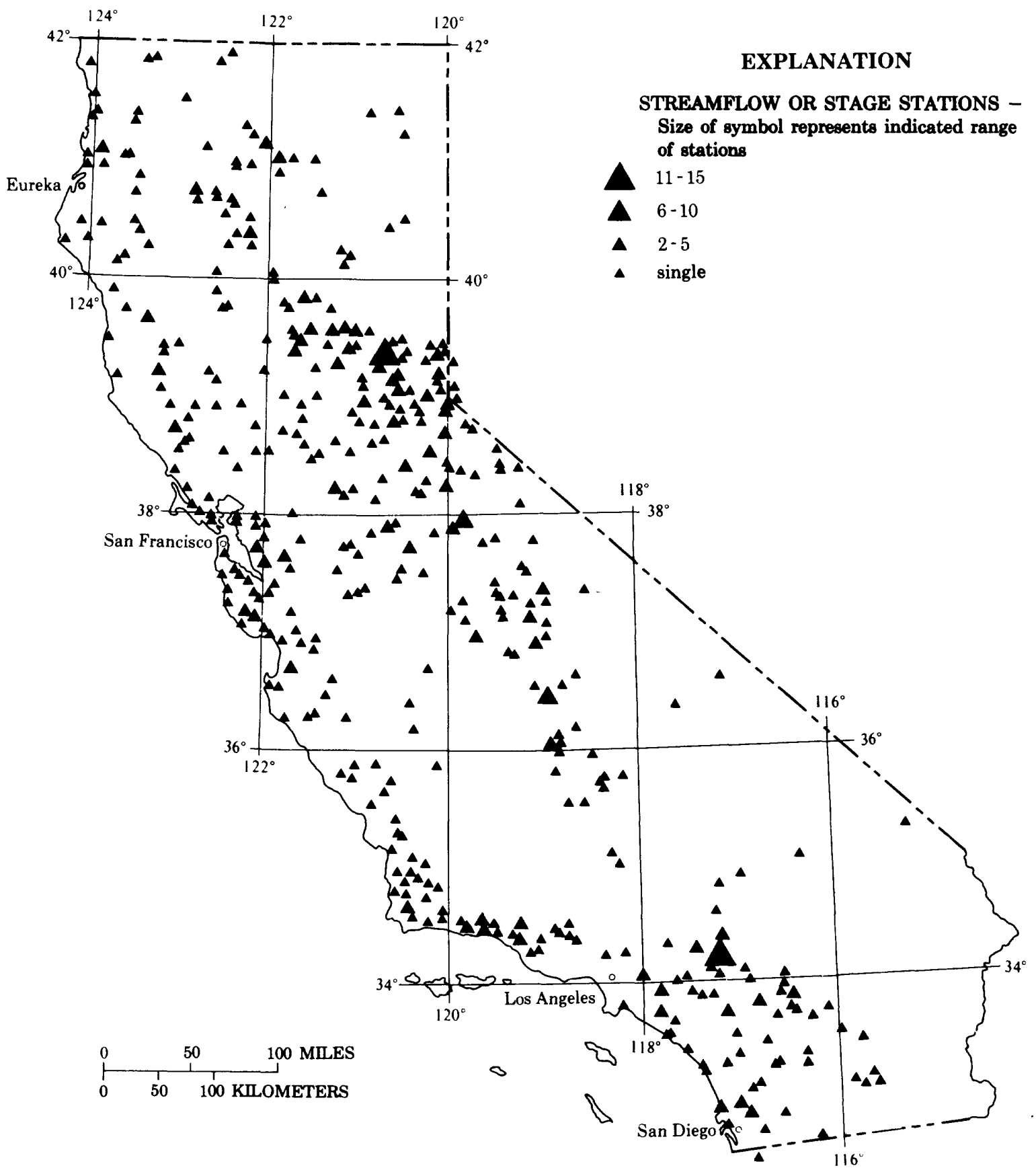

Location of streamflow-measuring stations 


\section{GROUND-WATER STATIONS}

Number: CA002

Location: Statewide (See accompanying map)

Project Chief: Charles E. Lamb

Period of Project: Continuing

Problem: Ground-water sources supplied about 40 percent of the total offstream fresh water used in California during 1985--about 14.8 billion gallons per day. More than 18 million people, almost 70 percent of California's population, used ground-water supplies. Of the 30.6 billion gallons per day used for irrigation in California, 10.4 billion gallons per day was withdrawn from ground-water sources. Ground-water quality and distribution is highly variable, and is related to geologic influences and to natural and manmade stresses. Monitoring of ground-water levels and chemistry is essential to the management and development of the resource.

Objectives: Collect ground-water-level data to meet the needs for assessment of quantity, quality, and occurrence of ground water. These data will be useful to Federal, State, and local water planners.

Approach: Water-level data recorded continuously, monthly, semiannually, and annually will be entered into a computer data base. Standard methods of data collection will be used as described in the "National Handbook of Recommended Methods for Water-Data Acquisition" and Water Resources Division manuals and memorandums.

Progress:

FY1988: Ground-water-level data from 935 long-term sites, 447 short-term sites, and 16 continuousrecorder wells were collected and compiled for publication. Data for water year 1986 were published in a separate volume of the annual data-report series.

FY1989: Ground-water-level data from 1,028 long-term sites, 57 short-term sites, and 20 continuous-recorder wells were collected and compiled for publication. Data for water years 1987 and 1988 were published in separate volumes of the annual data-report series.

FY1990: Ground-water-level data from 942 long-term sites, 95 short-term sites, and 17 continuousrecorder wells were collected and compiled for publication. Data for water year 1989 were published in a separate volume of the annual data-report series.

Plans for Next Year: Data collection and compilation will continue. All data will be published in a separate volume of the annual data-report series.

\section{Reports:}

U.S. Geological Survey, 1988, Water resources data--Califomia, water year 1986: U.S. Geological Survey Water-Data Report CA-86-5.

U.S. Geological Survey, 1988, Water resources data--California, water year 1987: U.S. Geological Survey Water-Data Report CA-87-5.

U.S. Geological Survey, 1989, Water resources data--California, water year 1988: U.S. Geological Survey Water-Data Reports CA-88-5.

U.S. Geological Survey, 1990, Water resources data--California, water year 1989: U.S. Geological Survey Water-Data Report CA-89-5. 


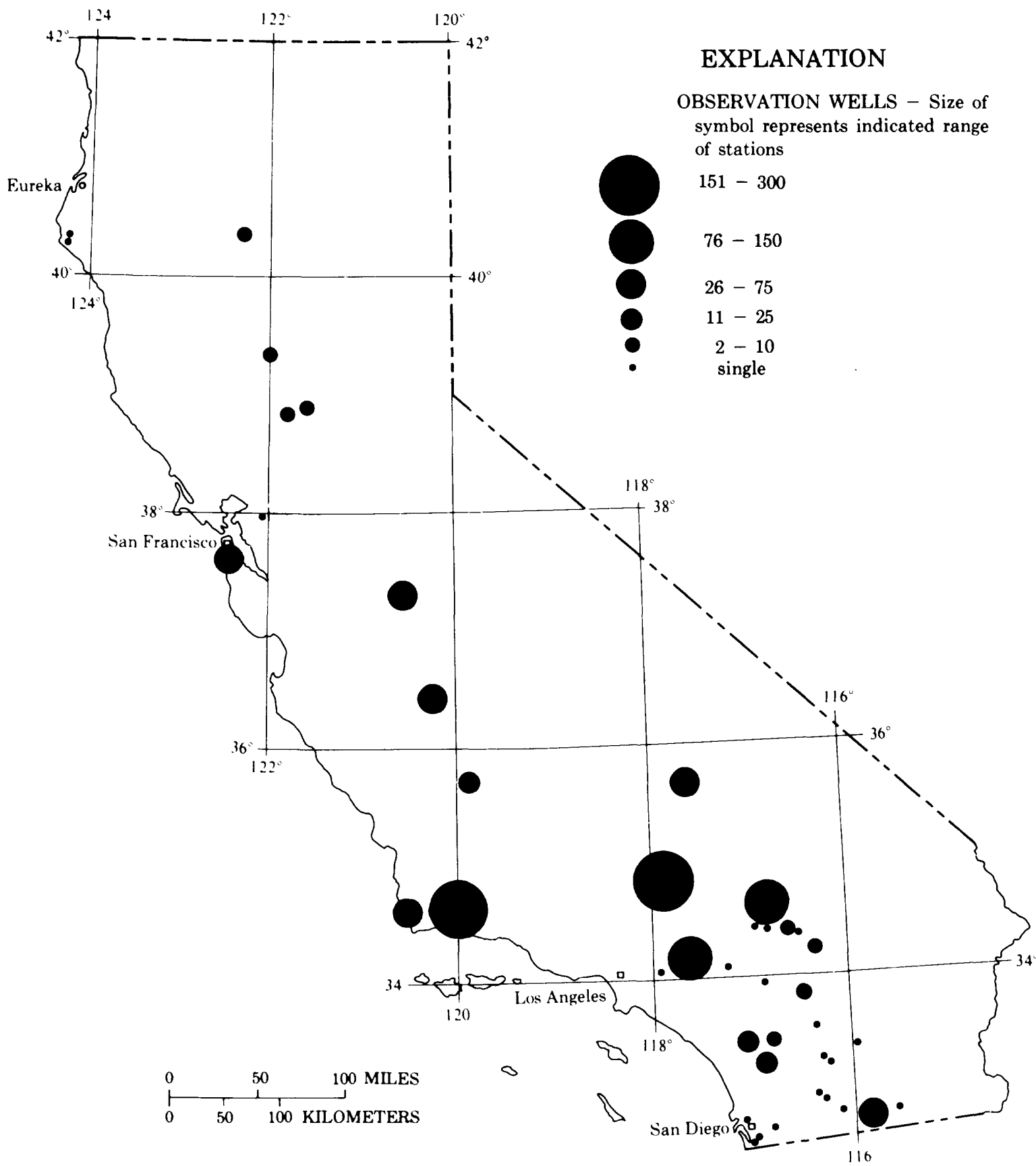

Location of selected observation wells. 


\section{WATER-QUALITY STATIONS}

Number: CA003

Location: Statewide (See accompanying map. Also see map of selected observation wells, page 19)

Project Chief: Rick T. Iwatsubo

Period of Project: Continuing

Problem: In order to properly manage the water resources of the State, the chemical quality of surface and ground water must be defined and monitored.

Objectives: Collect and publish long- and short-term records of water quality at selected stream, reservoir, precipitation, and spring sites and ground-water observation wells throughout California. The data will be used by Federal, State, and local agencies in the assessment, management, development, and protection of the State's water resources.

Approach: A network of water-quality sites will be established and operated to provide physical, chemical, and biological data for the objectives stated above. Standard methods of data collection will be used as described in the "National Handbook of Recommended Methods for Water-Data Acquisition" and Water Resources Division manuals and memorandums.

\section{Progress:}

FY1988: Water-quality data were collected periodically at many sites located throughout California. Water-quality samples were collected bimonthly at 12 and quarterly at 7 National Stream Quality Accounting Network (NASQAN) stations, and quarterly at 3 Hydrologic Benchmark stations. Water temperature and specific conductance were measured continuously at 33 and 3 sites, respectively. Precipitation samples were collected weekly at the National Trends Network stations in the Los Padres National Forest and at Yreka. Water-quality data also were collected at 135 stream and reservoir sites. Chemical analyses of ground-water samples from 184 long-term observation wells and 45 short-term observation wells were completed. Data for water years 1986 and 1987 were published in the annual datareport series.

FY1989: Water-quality data were collected periodically at many sites throughout California. Waterquality samples were collected bimonthly at 12 and quarterly at 7 NASQAN stations, and quarterly at 3 Hydrologic Benchmark stations. Water temperature and specific conductance were measured continuously at 38 and 13 sites, respectively. Precipitation samples were collected weekly at the National Trends Network stations in the Los Padres National Forest and at Yreka. Water-quality data also were collected at 53 stream and reservoir sites. Chemical analyses of ground-water samples from 290 long-term observation wells and 22 short-term observation wells were completed. Data for water year 1988 were published in the annual data-report series.

FY1990: Water-quality data were collected periodically at many sites throughout California. Waterquality samples were collected bimonthly at 12 and quarterly at 7 NASQAN stations, and quarterly at 3 Hydrologic Benchmark stations. Water temperature and specific conductance were measured continuously at 30 and 7 sites, respectively. Precipitation samples were collected weekly at the National Trends Network stations in the Los Padres National Forest and at Yreka. Water-quality data also were collected at 59 stream and reservoir sites. Chemical analyses of ground-water samples from 315 long-term observation wells and 59 short-term observation wells were completed. Data for water year 1989 were published in the annual data-report series.

Plans for Next Year: Collection of water-quality data will continue. 


\section{Reports:}

U.S. Geological Survey, 1988, Water resources data--California, water year 1986: U.S. Geological Survey Water-Data Reports CA-86-1 to CA-86-5.

U.S. Geological Survey, 1988, Water resources data--California, water year 1987: U.S. Geological Survey Water-Data Reports CA-87-1 to CA-87-5.

U.S. Geological Survey, 1989, Water resources data--California, water year 1988: U.S. Geological Survey Water-Data Reports CA-88-1 to CA-88-5.

U.S. Geological Survey, 1990, Water resources data--California, water year 1989: U.S. Geological Survey Water-Data Reports CA-89-1 to CA-89-5.

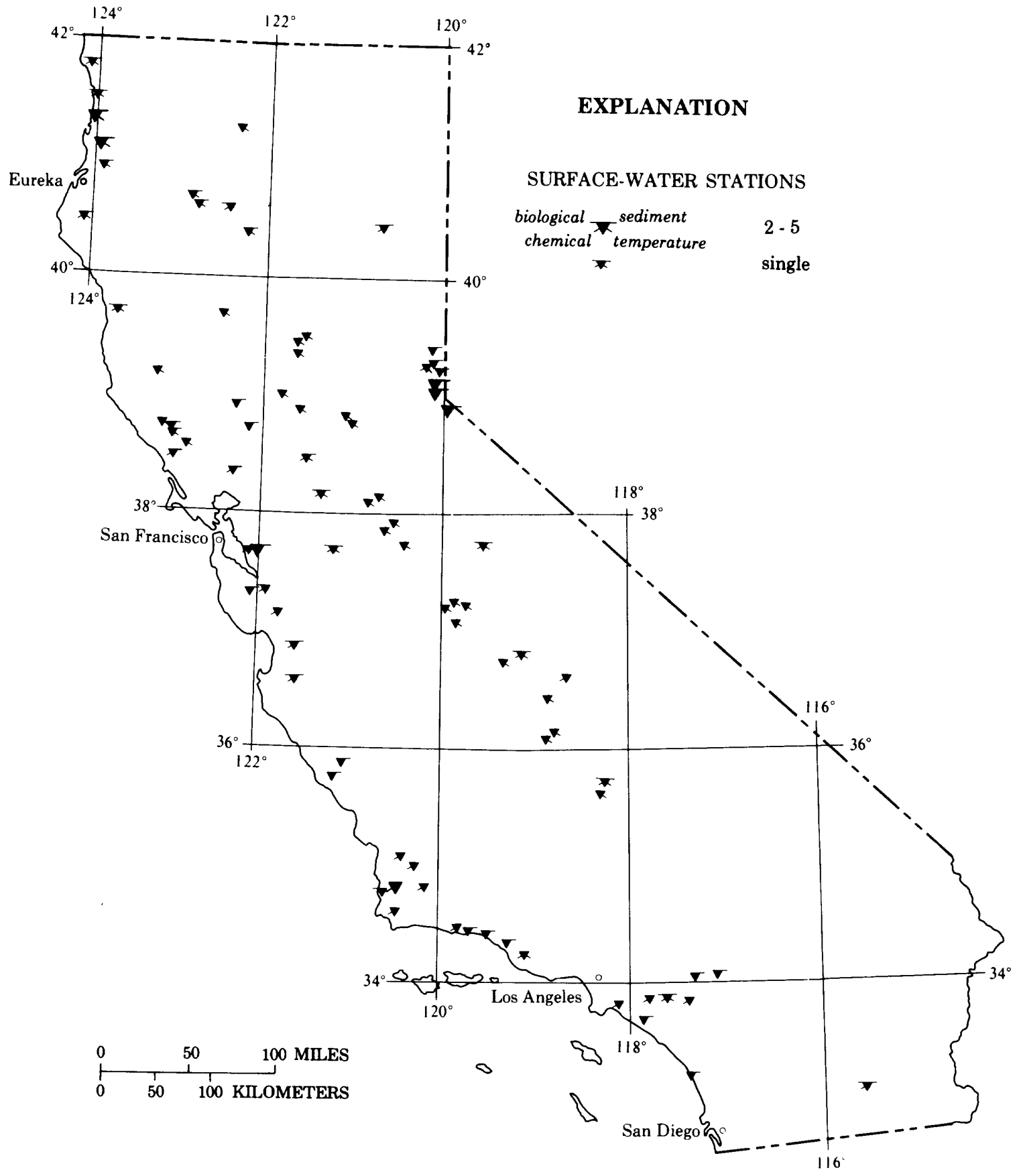

Location of surface-water-quality monitoring stations. 


\section{SEDIMENT STATIONS}

Number: CA004

Location: Statewide (See accompanying map for water-quality stations, page 21)

Project Chief: James M. Knott

Period of Project: Continuing

Problem: Erosion, transport, and deposition of sediment can have major adverse effects on lakes, streams, and adjacent lands, which may persist for years, decades, or even centuries. Knowledge of sediment transported by streams is essential in the development and management of water and land resources. Large variations in drainage-basin and precipitation characteristics in California result in significant differences in the quantity and composition of fluvial sediment. To obtain knowledge of sediment-transport characteristics of California's wide diversity of streams will require close monitoring of sediment at many locations.

Objectives: Provide sediment data that can be used to (1) develop land-management practices that will minimizie erosion rates; (2) evaluate the effects of significant increases or decreases in the supply of sediment to lakes and streams; (3) determine the effects of debris basins and drop structures on sediment transport; (4) monitor reservoir-capacity losses for flood-control and water-supply purposes; (5) determine the relation of sediment to algae growth in lakes; (6) evaluate changes in coastal morphology caused by changes in sediment discharge of coastal rivers; and (7) estimate changes in stream characteristics that may result from dams.

Approach: Suspended-sediment and bed-material samples will be collected at specific sites on streams within the State. Bed-load samples will be collected at those sites that are total-load stations if stream characteristics are suitable. Daily suspended-sediment concentration and discharge will be compiled for daily sediment stations. Monthly bedload discharge will be estimated for daily total-load stations. Selected sediment samples will be analyzed for particle-size distribution. Standard methods of data collection will be used as described in the series "Techniques of Water-Resources Investigations of the U.S. Geological Survey."

\section{Progress:}

FY1988: Sediment data collected at 16 daily, 26 periodic, 19 NASQAN, and 3 Hydrologic Benchmark stations during water year 1988 were compiled and reviewed. Sediment data collected during water years 1986 and 1987 were published in the annual data-report series.

FY1989: Sediment data collected at 15 daily, 21 periodic, 18 NASQAN, and 3 Hydrologic Benchmark stations during water year 1989 were compiled and reviewed. Sediment data collected during water year 1988 were published in the annual data-report series.

FY1990: Sediment data collected at 16 daily, 21 periodic, 18 NASQAN, and 3 Hydrologic Benchmark stations during water 1990 were compiled and reviewed. Sediment data collected during water year 1989 were published in the annual data-report series.

Plans for Next Year: Collection of sediment data will continue.

Reports:

U.S. Geological Survey, 1988, Water resources data--California, water year 1986: U.S. Geological Survey Water-Data Reports CA-86-1 to CA-86-4.

U.S. Geological Survey, 1988, Water resources data--California, water year 1987: U.S. Geological Survey Water-Data Reports CA-87-1 to CA-87-4.

U.S. Geological Survey, 1989, Water resources data--California, water year 1988: U.S. Geological Survey Water-Data Reports CA-88-1 to CA-88-4.

U.S. Geological Survey, 1990, Water resources data--Califomia, water year 1989: U.S. Geological Survcy Water-Data Reports CA-89-1 to CA-89-4. 


\section{NATIONAL TRENDS NETWORK FOR MONITORING ATMOSPHERIC DEPOSITION}

Number: CA005

Cooperating Agency: None. (U.S. Geological Survey Federal Program)

Project Chief: Kenneth W. Lee

Period of Project: Continuing

Problem: Some lakes in the United States are becoming more acidic, fish are no longer found in them, and the $\mathrm{pH}$ of precipitation is as low as 4.0. One question being asked is "What is the areal and temporal variation of wet-atmospheric deposition in the United States?"

Objectives: Sample and analyze wet-atmospheric deposition and determine the annual deposition rate in areas of California. Sites are part of a National program.

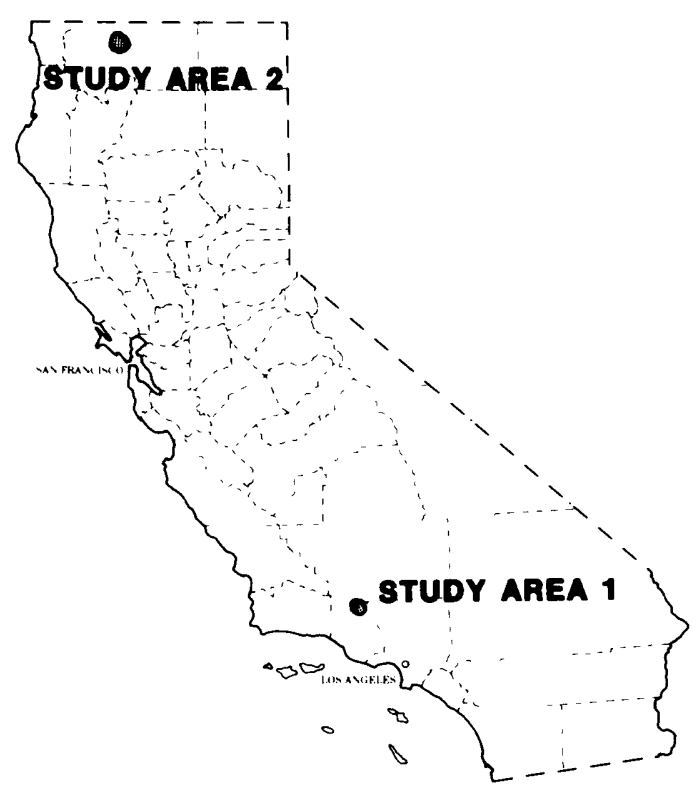

Approach: One atmospheric-deposition sampler will be installed and operated at Chuchupate Ranger Station in Los Padres National Forest in Ventura County (study area 1). Samples will be collected weekly for analysis, thereafter, the data are handled by the National program. The district will provide quality assurance on sampling techniques for a site near Yreka (study area 2) operated by the Siskiyou County Air Pollution Control District.

\section{Progress:}

FY1988 to 1990: The California District operated one station at Chuchupate Ranger Station with assistance from the Forest Service and provided quality-assurance reviews for one station near Yreka.

Plans for Next Year: Collection and analyses of atmospheric-deposition samples at Chuchupate will continue and rain gages will continue to be read. Inspections of the Yreka site will continue once or twice annually.

Reports: None. 


\section{WATER-USE INFORMATION FOR CALIFORNIA}

Number: CA007

\section{Cooperating Agency: California Department of Water Resources}

Project Chief: William E. Templin

Period of Project: Continuing

Problem: Nationwide, statewide, and site-specific estimates of water use are needed to establish waterresources policies and to conduct hydrologic investigations; estimates must be consistent in water-use categories and methods of determination to allow valid comparisons of statewide totals. California continually has the largest water-use volume of any state in the Nation; its multiagency water-management organizational structure and sheer magnitude of water users create a complex water-use information environment. The problem is to meet present and future water-use information needs in the most efficient and cost-effective manner.

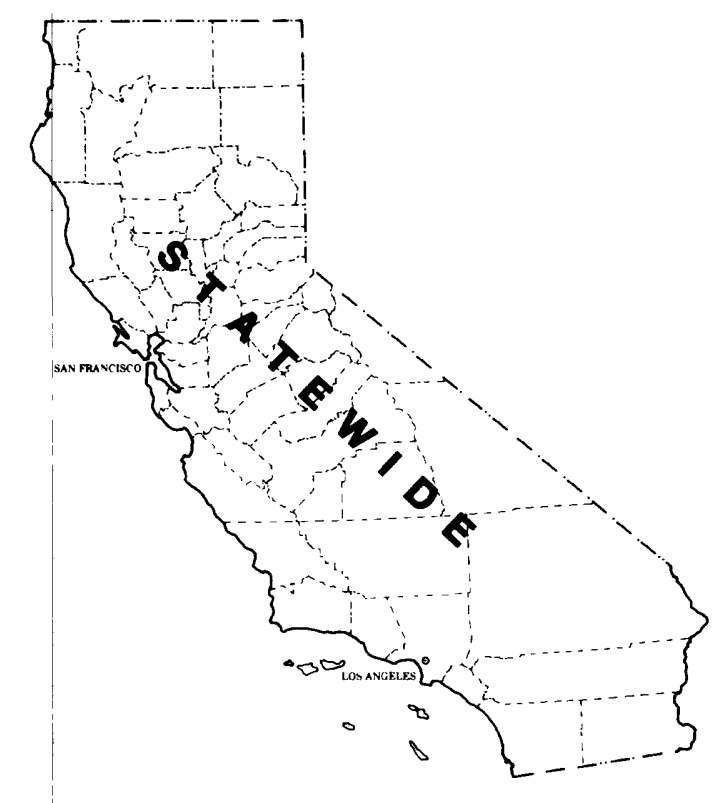

Objectives: (1) Determine how much fresh and saline surface and ground water is withdrawn and for what purposes, how much of this water is consumed during use, and how much water is returned to surface and underground sources after use; (2) maintain and refine computerized systems to store and retrieve statewide and site-specific water-use information; (3) devise and apply new methods and techniques to improve the collection, analysis, and dissemination of water-use information; (4) explain the values and applications of water-use information, and make this information available.

Approach: Information will be developed for 14 National Water Use categories: irrigation; industrial; commercial; domestic; water supply; sewage treatment; mining; livestock (animal specialties); reservoir evaporation (beginning in 1990); hydroelectric power, and 3 thermoelectric power categories: nuclear, fossil fuel, and geothermal. Site-specific information will be input into a Water Use Data System. Statewide information will be input into an aggregated Water Use Data System. Methods and techniques for collection, storage, and dissemination of water-use information will be improved.

\section{Progress:}

FY1988: A water-use geographic information system was initiated that includes subdirectories for SiteSpecific Water Use Data, Aggregated Water Use Data, and digital map coverages for California. The aggregated data were developed for the 1985 edition of the Geological Survey's 5-year interval water use circulars titled "Estimated Use of Water in the United States." This data base has aggregated total water use estimates for each of California's 58 counties, 16 subregions, and 149 hydrologic cataloging units. Each aggregated area has water-use estimates for the 12 nationally determined water-use categories and more than 120 data elements. The digital map coverages include county and drainage-basin boundaries, streams, water bodies, and dams. A paper was published and an oral presentation was given on the California Water Use GIS at the American Water Resources Association (AWRA) Symposium in August 1988. A poster showing how California was the Nation's leading water use State again in 1985 was prepared and displayed at the same AWRA Symposium. Projects were initiated to provide ground-water pumpage estimates from power consumption records for parts of Tulare, Kings, and Fresno counties. 
FY1989: The Water-Use Program's main success in fiscal year 1989 was coordinating with other National and California District operations. A paper titled "California Water Supply and Use" was included in the U.S. Geological Survey National Water Summary 1987. Water use tables and water budgets are now being used widely in District operations. Irrigation water supply and demand information was determined from records of 32 water districts in the western San Joaquin Valley. Pumpage related projects have compiled power consumption data into ARC/INFO files and coverages, and estimates of pumpage for areas in the San Joaquin Valley.

Our point data base (INFOWUDS) contents were expanded with data for water-supply wells, sewagetreatment plants, nuclear powerplants, and hydropower plants. The need for water-use information was included in monitoring objectives developed for two reports evaluating water-resource data networks in Monterey County.

FY1990: The Water-use Program's concentration in fiscal year 1990 was on reviewing the aggregated water-use estimates for 1985 and preparing for the 1990 update. Water-use estimates and methods for 1985 were reviewed and a quality assurance plan was drafted. A handout was prepared and a presentation was given at the National U.S. Geological Survey Water Use Conference/Workshop in Denver. A presentation was given at the annual meeting of the American Association for the Advancement of Science. A proposal was prepared on the work needed to complete Chapter 11, Water Use, for the National Handbook of Recommended Methods for Water Data Acquisition. Our Pumpage Library and related projects have compiled power consumption data into ARC/INFO files and coverages, and estimates of pumpage for areas in central California. Our site-specific data base (INFOWUDS) was expanded with data for locations of mines, thermoelectric powerplants, hydropower plants, wastewater treatment plants, and reservoirs (for the new Reservoir Evaporation category). Our aggregated data base (AWUDS) was expanded to include information on crop acreages, by county, for 1985 through 1989, and a survey of water suppliers, their sources and volumes delivered in 1989.

Plans for Next Year: Water use in 1990 will be estimated for all California counties, hydrologic units, and major aquifers. A water use data base for Antelope Valley will be developed. Chapter 11, Water Use, will be completed for the National Handbook of Recommended Methods for Data Acquisition. A data report will be published containing water delivery and crop information for the west side of the San Joaquin Valley. Power-consumption data will continue to be collected and ground-water withdrawals will be estimated.

\section{Reports:}

Templin, W.E., 1988, The California water-use geographic information system, in Waterstone, Marvin, and Burt, R.J., eds., Symposium on water-use data for water resources management, Proceedings: Bethesda, Maryland, American Water Resources Association, Technical Publication Series TPS-88-2, p. 77-84.

Templin, W.E., 1990, Reporting of agricultural water use information for California and the Western States (abs.): American Association for the Advancement of Science, Pacific Division, 71st, v. 9, part 1, p. 54.

Templin, W.E., 1990, California water supply and use, in National Water Summary 1987--Hydrologic events and water supply and use: U.S. Geological Survey Water-Supply Paper 2350, p. 173-182. 


\section{GROUND-WATER APPRAISAL, U.S. MARINE CORPS BASE, TWENTYNINE PALMS}

Number: CA027

Cooperating Agency: U.S. Marine Corps, Air Ground Combat Center, Twentynine Palms

Project Chief: Charles A. Kaehler

Period of Project: September 1981 to September 1988

Problem: Most of the water supply for the Twentynine Palms Marine Corps base is obtained from wells in the Surprise Springs ground-water basin, about 10 miles northwest of headquarters in the Mesquite basin. To use this supply of potable, but distant, water efficiently, the Marine Corps would like to develop alternative sources of ground water for two specific needs: (1) production of about 250 gallons per minute to be used for landscape irrigation at the housing area near the golf course; and (2) production of a minimum of about 100 gallons per minute for a planned facility to wash vehicles. Hydrogeologic information on the Mesquite basin is limited.

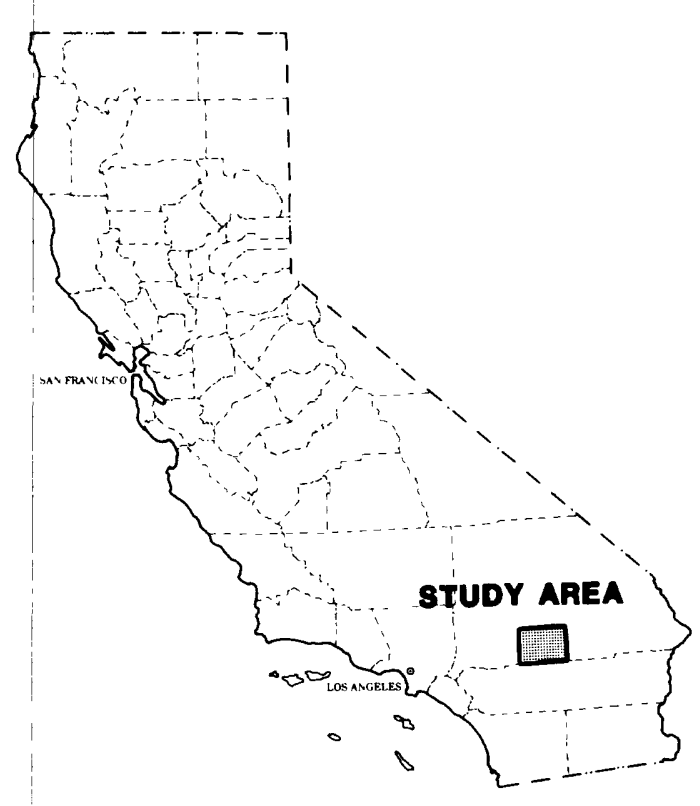

Objectives: Drill, construct, and test two wells in the Mesquite basin area and expand on the limited information available on the hydrogeology of the Mesquite basin.

Approach: All available hydrogeologic data for the Mesquite basin will be reviewed, and designs for the two wells will be formulated. The two sites will be selected on the basis of a hydrologic assessment of the area and on the needs of the Marine Corps. The wells will be constructed and developed using U.S. Geological Survey drilling equipment. After the wells are constructed and developed, pumping tests will be done to determine well yield and drawdown. Water samples will be collected for analysis of major ions, fluoride, nitrate, boron, and dissolved solids.

\section{Progress:}

FY1988: A report describing the geohydrology and effects of water use in the Surprise Spring basin was written and reviewed. The report describes model simulations of projected pumpage from three proposed supply wells located north and west of existing supply wells in the basin. In April and May 1988, these wells were constructed and test pumped. During the test, all three wells were pumped dry, which indicates that, if the wells were properly constructed, the hydraulic conductivity near the wells is significantly lower than that used in the model. These results caused concern that the calibrated model was invalid. The Survey suggested that the new wells be further developed and retested with a smaller capacity pump. After additional development, all the wells produced more than 1,000 gallons per minute, supporting the validity of the calibrated model.

FY1989: Ground-water levels and chemical quality were monitored. Water levels were measured semiannually in 16 wells in the Surprise Springs basin, semiannually in 1 well in the Mesquite basin, and annually in 2 wells in the Deadman basin. Three wells in the Surprise Springs basin were sampled for chemical analyses. 
FY1990: Two 8-inch diameter wells were drilled, completed, tested, and sampled in the Mesquite basin. Information gained during the construction of the wash-rack well $(2 \mathrm{~N} / 9 \mathrm{E}-20 \mathrm{M} 1)$ showed that coarsegrained water-bearing deposits do exist in the northeast part of the Mesquite basin despite the proximity of bedrock outcrops to the east and fine-grained lake deposits to the south. The measured water level, about 1,545 feet above sea level, was 125 feet lower than expected from projection of the nearest waterlevel measurement 2.5 miles to the south. Geophysical logs indicated a possible near-surface zone of perched water. An aquifer test was done in June 1990. At a pumping rate of 20 gallons per minute, drawdown was about 0.5 foot. The data indicated a transmissivity of about 40,000 feet squared per day, and a specific capacity of about 40 gallons per minute per foot of drawdown. The water level in the new golf course well was 55 feet higher than that projected from the existing well 1,100 feet to the east, which suggests that a previously unrecognized branch of the Mesquite fault between the two wells acts as a partial barrier to ground-water flow. During the week of September 24, 1990, the well was pumped at 200 gallons per minute for 49.5 hours; drawdown was 20.3 feet (specific capacity of 10 gallons per minute per foot of drawdown). Field measurements during the test indicated a $\mathrm{pH}$ of 9.1 , a specific conductance of 1,080 microsiemens per centimeter, and an alkalinity of 36 milligrams per liter as calcium carbonate.

Plans for Next Year: Aquifer-test data will be analyzed, and all data will be transmitted to the cooperator.

\section{Reports:}

Londquist, C.J., and Martin, Peter, 1991, Geohydrology and ground-water-flow simulation of the Surprise Spring basin aquifer system, San Bernardino County, California: U.S. Geological Survey WaterResources Investigations Report 89-4099, 41 p. 


\section{APPRAISAL OF GROUND-WATER RESOURCES, INDIAN WELLS VALLEY}

Number: CA030

Cooperating Agencies: Indian Wells Valley Water District; and U.S. Navy, Naval Weapons Center, China Lake

Project Chief: Charles E. Berenbrock

Period of Project: Continuing

Problem: Indian Wells Valley is undergoing rapid population growth and is faced with the problem of managing water resources of the area in order to best meet future needs.

Objectives: Define current ground-water conditions in the valley using a water-level and water-quality monitoring network and develop a computer model that can be used to predict aquifer response to future ground-water development.

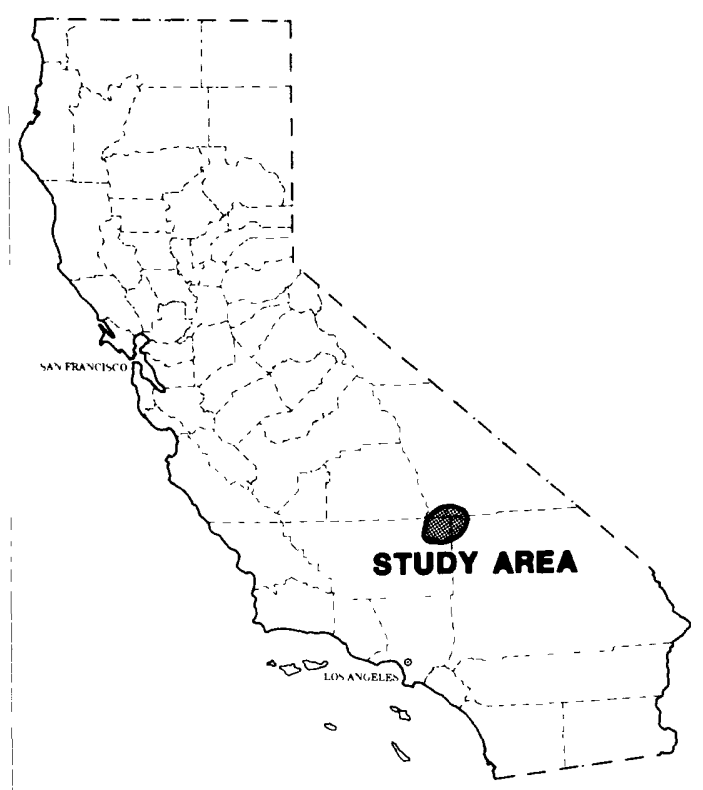

Approach: Water levels will be measured; ground-water pumpage will be estimated, and samples for chemical analyses will be collected. Previous model data will be reorganized and reevaluated to develop a steady-state and transient-state digital flow model of the basin using the U.S. Geological Survey Modular Model. The flow model will be used to predict ground-water levels primarily in the current pumping centers of the basin under selected management alternatives. Current and historical chemical data will be used to define variations in chemical quality of ground water. A solute-transport model will be used to predict the movement of solutes in response to pumping.

\section{Progress:}

FY1988: A water-level and water-quality monitoring network was operated during the year. Water levels were measured semiannually in 22 wells and water samples were collected annually from 10 wells for chemical analysis of major dissolved ions. Three of these samples also were analyzed for volatile organic compounds and trace metals. An additional 30 wells were sampled for major dissolved ions for the valleywide ground-water quality study. Assistance was given to China Lake Naval Weapons Center and the U.S. Navy Seabees on construction of observation wells. A report describing the calibration of a three-dimensional ground-water-flow model and the geohydrology of the valley was submitted for review. A 2-year valleywide ground-water quality study was started in 1987, and historical and current waterquality data were evaluated. Development and calibration of a solute-transport model was started. Results from preliminary simulations of the solute-transport model indicated that additional water-quality data are needed in the northeastern and eastern parts of the valley.

FY1989: Operation of the water-level and water-quality monitoring network continued. Survey assistance in construction of test holes continued and assistance was given to the Indian Wells Valley Water District on a 24-hour pumping test in the southwestern part of the valley. The valleywide ground-water quality study continued. Solutes in the main water-bearing zone (deep aquifer) were simulated by a two-dimensional solute-transport model of the valley. Concentrations simulated by the model generally matched measured concentrations except in areas adjacent to the lacustrine deposits. Additional data need to be collected in these areas before this part of the valley can be adequately simulated. 
FY1990: The report describing the ground-water-flow system in Indian Wells Valley was completed. A report describing variations in water quality, processes that affect chemical quality, variations in oxygenand hydrogen-isotope concentrations, and computer simulations of solute transport in Indian Wells Valley was written and in review.

Plans for Next Year: The water-quality report will be completed. A network of wells for continued monitoring of ground-water levels and water quality in Indian Wells Valley will be maintained.

\section{Reports:}

Berenbrock, Charles, and Martin, Peter, 1991, Ground-water flow system in Indian Wells Valley, Kem, Inyo, and San Bernardino Counties, California: Water-Resources Investigations Report 89-4191, $88 \mathrm{p}$. 


\section{SACRAMENTO RIVER BETWEEN HAMILTON CITY AND BUTTE CITY}

Number: CA271

Cooperating Agency: Califomia Department of Water Resources

Project Chief: Jerry G. Harmon

Period of Project: Continuing

Problem: Flooding in the Sacramento River basin may cause changes in the magnitude and duration of overbank flows to Butte basin and increased amounts of lateral erosion. Continued lateral migration of the channel may cause the Sacramento River to change course and enter Butte basin or allow excessive flows down the main channel of the river, where the design channel capacity decreases in leveed reaches.

Objectives: (1) Define relations and document changes in the proportional division of floodflows between the Sacramento River and Butte basin; (2) show the results of channel scour, channel fill, and streambank erosion at monumented cross sections of the river, and (3) present water-surface profiles of floods to provide a base for documenting changes in channel-flow characteristics.

Approach: Flood data (part of the ongoing data-collection program) will be collected. Channel crosssection data at monumented sites will be collected annually. Flood data will include streamflow and surveyed or recorded stage measurements.

\section{Progress:}

FY1988: Recording gages and crest-stage gages were installed and operated during the flood season. Annual cross-section surveys were completed at monumented sites in August 1988. Flood data for 1980-86 were reviewed and tabulated.

FY1989: A network of 39 crest-stage gages and 5 recording gages in Butte basin and the Sacramento River was operated during 1988-89. Worn and obsolete gaging equipment was replaced. Crest-stage gages were added at two sites. Level surveys were done to check and establish reference marks and crest-stage gage elevations. Annual surveys of cross sections of the main channel of the river at monumented sites were completed in September 1989.

FY1990: A Water-Resources Investigations Report on the floods of 1980-86 and a data report were written and are in review. Annual cross-section surveys of the main channel of the river at monumented sites were completed in August 1990. Level surveys were done to check and establish reference marks and crest-stage gage elevations.

Plans for Next Year: Recording gages and crest-stage gages will be in operation during the 1990-91 flood season. The data-collection network will be modified to include peak-stage data near Parrott Weir, which was constructed in 1988. Elevations and descriptions of reference marks are documented to relate floodflow measurements and surveys of high water marks along the Sacramento River and in Butte basin. Flows will be measured and recorded to document changes or stability in characteristics of floodflows. Monumented cross sections of the river will be resurveyed annually and compared with data from previous surveys at each of seven sites. A report will be written after the next flood to document changes in floodflow characteristics following an extended drought period.

Reports: None. 


\section{GROUND-WATER RESOURCES OF THE SANTA BARBARA AREA}

Number: CA342

Cooperating Agency: Santa Barbara, city of

Project Chief: John R. Freckleton

Period of Project: July 1977 to September 1991

Problem: The reduced efficiency of surface reservoirs due to siltation will place increasing pressure on the ground-water supply in the Santa Barbara ground-water basin. Because of anticipated pumpage in the basin and the possibility of seawater intrusion into the freshwater aquifer, it has become necessary to develop and implement a ground-water program capable of evaluating the effects of anticipated stresses on the ground-water basin.

Objectives: Design a comprehensive program to regularly monitor water levels and water quality in the ground-water basin to measure the effects of increased

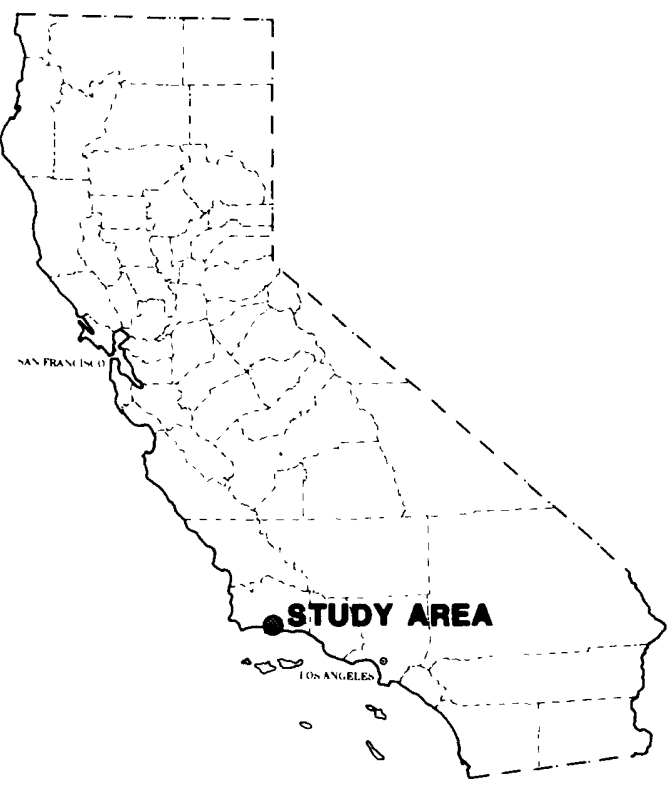
pumping and the potential movement of seawater into the ground-water reservoir. Results of the monitoring program will be used to develop a computer model of the ground-water basin that will help define the hydrogeology and will aid in the management of the water resources of the basin.

Approach: Previous investigations will be reviewed. Historical water-level and water-quality data and rainfall and streamflow records will be collected and analyzed. Additional hydraulic data, such as storage coefficient and transmissivity estimates, will be collected. A finite-difference flow model based on measured or estimated hydraulic properties and known or estimated values of recharge and discharge will be developed. The mathematical model will be used to investigate various pumping alternatives that may lessen the effects of increased pumping in the subbasin.

\section{Progress:}

FY1988: A report describing the geohydrology of the Foothill ground-water basin near Santa Barbara was written and is in review.

FY1989: Nine test wells (three sets of three nested 2-inch wells) were drilled in Storage Unit III of the Santa Barbara ground-water basin, and one 6-inch test well was drilled in discharge area 2 of the Foothill ground-water basin. Electric-log and water-level data obtained from these wells will be used to develop a geohydrologic concept of Storage Unit III. Preliminary data obtained from the Storage Unit III test wells indicated a more complex ground-water system than was anticipated.

FY1990: A report describing the geohydrology of the Foothill ground-water basin was published. The scope and report-review submission date for this project were modified. The original scope included updating the Foothill model to incorporate monthly timesteps and to develop a flow model of Storage Unit III. The city of Santa Barbara and the Survey agreed that the new scope will include a combined-flow model of Foothill basin, Storage Unit I, and Storage Unit III. A flow-model grid of the three basins was developed. The fault boundaries separating the three basins were modeled using the U.S. Geological Survey Modular Model's "horizontal flow barrier" package. 
Plans for Next Year: The combined-flow model will be calibrated and will incorporate monthly timesteps for transient simulation. A report describing the model and simulations will be written.

\section{Reports:}

Freckleton, J.R., 1989, Geohydrology of the Foothill ground-water basin near Santa Barbara, California: U.S. Geological Survey Water-Resources Investigations Report 89-4017, 46 p. 


\section{DEVELOPMENT OF A MOVING-BOAT DISCHARGE-MEASURING SYSTEM USING AN ACOUSTIC DOPPLER CURRENT PROFILER}

Number: CA382

Cooperating Agency: None. (U.S. Geological Survey Federal Program)

Project Chief: Michael R. Simpson

\section{Period of Project: Continuing}

Problem: Accurate discharge measurements of large and(or) tidal-affected rivers cannot be made using conventional boat discharge-measurement techniques. In large rivers (more than 800 feet wide), the bank-to-bank tagline used for boat stationing becomes unwieldy and unsafe. In tidal-affected rivers, the duration of a conventional discharge measurement ( 1 hour or longer) does not permit accurate measurement of fast-changing discharges. Moving-boat discharge-measurement techniques developed by the Survey in an attempt to solve these problems have major deficiencies, which makes their use unadvisable when high accuracy and speed are desired, especially in tidal-affected rivers.

Objectives: (1) Develop and test a moving-boat discharge-measuring system using a vessel-mounted acoustic Doppler current profiler (ADCP). Tests have shown that an ADCP system is capable of measuring water velocities from a moving vessel and of calculating discharge if controlled by the proper software; (2) write and debug software that computes river discharge from data provided by the ADCP; and (3) install software on the ADCP system and field test.

Approach: The discharge-measurement software will be written in the Pascal language using generic Pascal tools and compiler directives so that the final source code will be transportable to computers other than the HP-9816. The program structure and documentation will conform to programming standards as set forth by the HIF (IDL). Field tests of the ADCP system will be done under steady-state and nonsteady-state flow conditions at two locations on the Sacramento River using an ADCP system mounted on the research vessel Saul E. Rantz. After the program is tested and debugged, the final source code and documentation will be available as a Primos file or in written form.

\section{Progress:}

FY1988: Initial tests were made comparing discharges collected with the moving-boat system with discharges provided by the acoustic velocity meter (AVM) on the Sacramento River at Freeport on December 18, 1987. Test results were excellent, and a refined version of the computer program was tested at the same location during the week of April 4, 1988. Test results again were excellent (within 4 percent of the AVM discharge). Some of the differences between AVM and moving-boat discharge measurements were due to deficiencies in the calibration of the AVM system (conventional discharge measurements were used to calibrate the AVM system). Several program flaws were discovered and the software was revised. Refinements to the software corrected problems with vertical velocity profile estimation, lost data recovery, and handling of bi-directional flow in the vertical profile. The system was used for several field applications which included two 26-hour tidal studies on the Sacramento River at Chipps Island; the calibration of two acoustic velocity meters at Beacon Island in the San Joaquin River Delta; and the calibration of a mathematical model used in the San Joaquin River Delta. This is the only discharge measurement system that could accomplish all the above-mentioned tasks. Using this system, three people made 160 measurements at 10 locations during a 2-day period.

FY1989: Development of the acoustic Doppler discharge measurement (ADDM) system was accomplished over a span of $21 / 2$ years. During that period, many problems were overcome, including estimation of missing parts of the water velocity profile that cannot be measured by the ADCP, estimation of the effects of bottom-sediment movement on ADCP discharge- measurement accuracy, and estimation of unmeasured discharge near the edges of the riverbank. 
Comparison tests and discharge-measurement error analysis have shown that discharge measurements made with the ADDM system are at least as accurate as those made using conventional discharge-measurement methods and have the advantage of being much faster to accomplish ( 2 minutes for the ADDM system compared with at least 1 hour for conventional discharge measurements). The ADCP dischargemeasurement system is perhaps the only such system that can quickly and accurately measure discharges in tidal-affected reaches of rivers or estuaries.

FY1990: A report describing the development of the ADDM system was written and reviewed. Review of error analysis of the ADDM system produced some questions, which required additional data collection to resolve. Water-velocity data were collected on the Sacramento River near Freeport during the second week of July 1990. The data were used to investigate the amount of total random uncertainty caused by errors in estimating depth average cross products (water velocity times boat velocity) in a subsection measured by the ADDM system. Results of the data analysis indicated that the uncertainty was 5.6 percent. Total ADDM system uncertainty (random and systematic) for a typical discharge measurement on the Sacramento River near Freeport was 1.6 percent. A statistician was contacted to review the above described error analysis.

Plans for Next Year: As soon as the statistical review is complete, the report will be sent for Director's approval. California District Computer support personnel will translate the prototype ADDM system discharge-measurement program (5,000 lines of Pascal code) into modular C. The translated program is slated to run on an IBM PC 386 or equivalent. A "Beta test" version of a new, high-resolution, broadband ADCP (BB-ADCP) system is being offered by the manufacturer, R.D. Instruments. The California District is requesting funds from the U.S. Geological Survey Office of Surface Water for the purchase of one of these new systems. The BB-ADCP can be used in shallow water (1 meter or less) and is an attractive alternative to many of the less-effective conventional discharge-measurement methods used by the Water Resources Division.

Reports: None. 


\section{GEOHYDROLOGIC STUDY OF COACHELLA VALLEY}

Number: CA387

\section{Cooperating Agency: California State Water Resources Control Board}

Project Chief: Eric G. Reichard

\section{Period of Project: October 1987 to September 1989}

Problem: The Coachella Valley, a basin with important potential for conjunctive use of ground and surface water, is facing increasing water demands as well as possible water-quality concerns. An assessment of the hydrogeologic system in the valley and the development of computer-simulation models will aid in developing future water-management plans.

Objectives: Compile, evaluate, and organize data on the geohydrology, water quality, water levels, recharge and

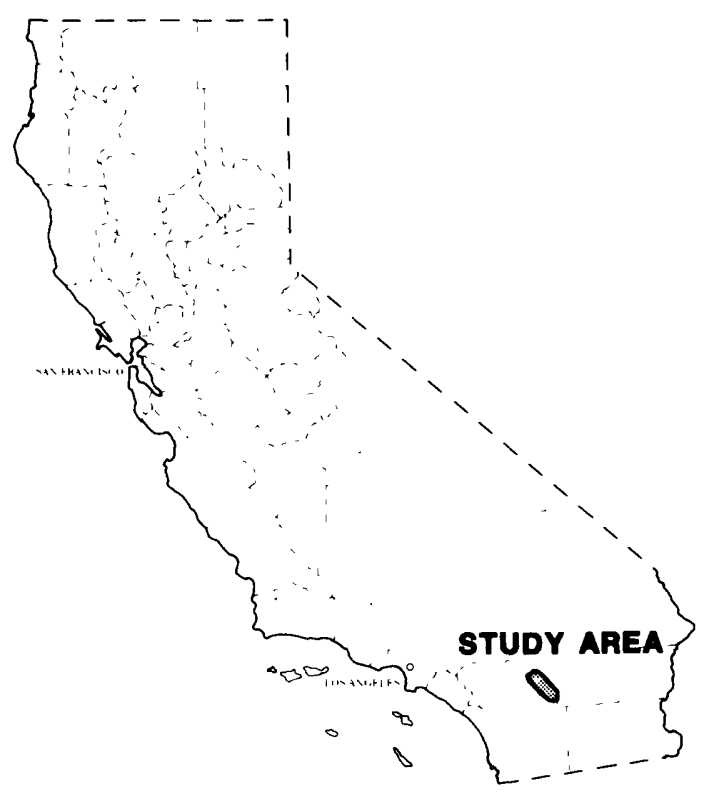
discharge rates, and land use of the basin. Characterize the hydrogeologic and geochemical systems in the basin.

Test the accuracy of existing flow and transport models in simulating conditions in the upper valley. Determine an appropriate approach for modeling valleywide ground-water flow and chemical transport on the basis of an evaluation of current and potential water-management issues in the basin and on data needs and availability. Design a work plan for developing valleywide ground-water models.

Approach: A computerized geohydrologic data base for the entire valley will be compiled and evaluated. The conceptualization of the geohydrologic system will be refined on the basis of these data. The existing ground-water model will be evaluated and used to simulate the effects of artificial recharge on water levels and water quality. A detailed work plan for carrying out a valleywide ground-water-modeling study will be formulated.

\section{Progress:}

FY1988: A geohydrologic data base for the Coachella Valley was compiled and the previous U.S. Geological Survey digital ground-water model of the upper Coachella Valley was evaluated. Data were compiled from within the Survey and from the Desert Water Agency, the Coachella Valley Water District, the Califomia Regional Water Quality Control Board, and the U.S. Bureau of Reclamation. A computerized data base, which includes digitized locations of wells and geohydrologic features, pumping rates, water levels, and limited water-quality data, was established. The data base was developed to allow efficient interaction with ground-water models. The input files from the Survey's 1978 digital groundwater model of the upper Coachella Valley were converted for use with SUTRA, a well-documented, commonly used ground-water-flow and transport model developed by the Survey. Preliminary verification runs of the model were done using data from 1979 to 1986, a period during which a large amount of artificial recharge occurred. These model runs allowed evaluation of the validity of original model assumptions concerning the basin water budget, aquifer characteristics, and boundary conditions.

FY1989: Geohydrologic data were analyzed to increase our knowledge of the ground-water-flow system and the water-quality effects of artificial recharge. The existing ground-water model of the upper Coachella Valley was used to simulate the effects of artificial recharge in the upper Coachella Valley from 1979 to 1986. A detailed work plan for future data collection and basinwide ground-water modeling was completed and submitted to the regional agencies. A water-resources investigations report was written. 
FY1990: The water-resources investigations report was submitted for colleague review.

Plans for Next Year: Complete report.

Reports: None. 


\title{
REAPPRAISAL OF THE GROUND-WATER BUDGET AT HONEY LAKE VALLEY, WASHOE COUNTY, NEVADA, AND LASSEN COUNTY, CALIFORNIA
}

Number: CA397

\author{
Cooperating Agency: California Department of Water \\ Resources
}

Project Chief: Clark J. Londquist

\section{Period of Project: October 1986 to September 1989}

Problem: Development of the Reno-Sparks area is increasing, nearly all economically available surface water has been allocated, and the demand for ground water continues to grow. Use of water from the Honey Lake aquifer is under consideration, but decisions concerning development of the aquifer are complicated by the institutional constraints of withdrawal from an interstate source as well as the physical limitations of ground-water availability in semiarid areas. Therefore, a detailed appraisal of the ground-water budget is needed.

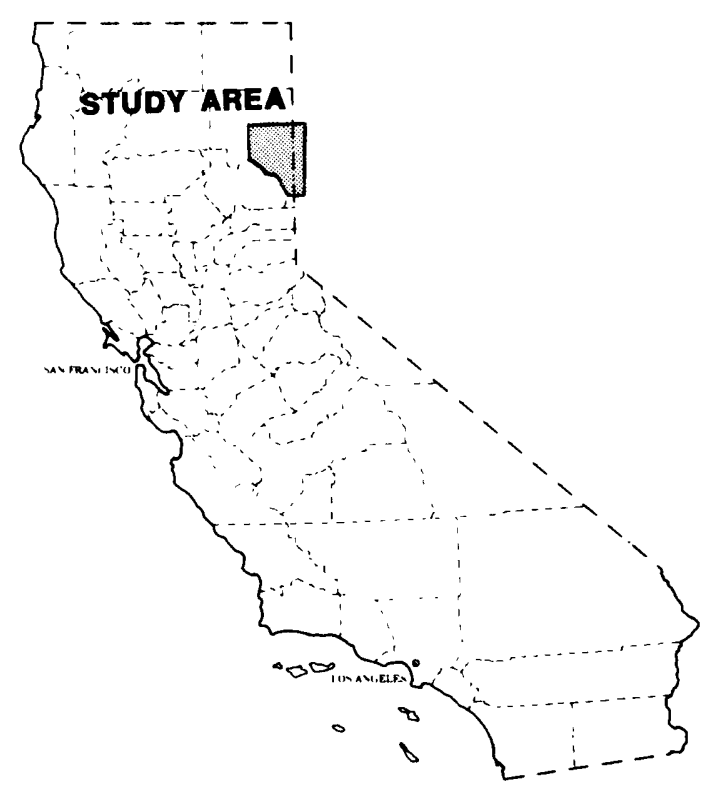

Objectives: Determine the components of ground-water flow and the hydraulic characteristics of the aquifer. Develop a digital model of the flow system to evaluate and quantify the ground-water budget. Prepare a report to disseminate the results of the study in a format and with language appropriate for understanding and use by water managers, water users, and elected officials.

Approach: Phase 1 will include assembly and evaluation of existing data, reconnaissance-level data collection, planning for additional detailed data collection, and flow-model development. Phase 2 will involve collection of additional field data to fill needs identified in Phase 1, interpretation of data, and revision of the model. Phase 3 will include completion of the model, calibration and sensitivity analysis, and preparation of the final report.

\section{Progress:}

FY1988: Seven wells were drilled and one well was rehabilitated. Six seismic refraction lines were run to determine depth to bedrock. Percentage of coarse-grained material from all available well logs were coded. Hydraulic conductivity from specific-capacity data and percentage of coarse-grained material data were estimated. Data were collected and dates were coded for entry into a deep percolation model that will be used to aid in determining a water budget for the study area. Water levels were measured in selected wells on a weekly or monthly basis. Stream discharge was measured on 21 small ungaged streams around the valley on a monthly basis. Three high-altitude precipitation storage gages were operated. Several runs were made of the preliminary Nevada area model. A ground-water-flow model of the entire alluvial basin was developed and several preliminary runs were made. The results of these runs indicated that additional data would be needed before a successful model could be assembled. A final model would cover only that part of the study area east of Honey Lake because of the limited data and available time.

FY1989: Streamflow and water-level measurements were completed in April 1989. Aquifer tests were done by the cooperator at existing irrigation wells in the Fish Springs Ranch area. Land-surface elevation at each of the observation wells in the area was determined by survey. This survey work confirmed that water was flowing out of the basin across the northeastern boundaries into Smoke Creek Desert and Pyramid Lake Valley. The deep percolation model was completed and used to estimate areal recharge for 
the entire study area. Estimates of surface-water flow within the entire basin were made, and a report was prepared describing the methods used and the results. A ground-water-flow model of the area east of Honey Lake, excluding Long Valley, was calibrated using areal recharge data from the deep percolation model and stream recharge data from estimates made for this study. The model includes both the basinfill material and the surrounding and underlying volcanics. The model was used to simulate the effects of pumping an additional 9,000 acre-feet per year from the basin, for a total pumpage of 15,000 acre-feet per year. The model indicated that the additional pumpage would be derived primarily from salvaged evapotranspiration and reduced outflow across the northeastern boundaries and that the system could support this level of pumping over the long term.

FY1990: Review response was completed, approval for publication was obtained, and three reports on the results of the study were printed.

Plans for Next Year: None. Project completed.

\section{Reports:}

Handman, E.H., 1990, Principal results of a ground-water study of Honey Lake Valley, California and Nevada: U.S. Geological Survey Open-File Report 90-155, 2 p.

Handman, E.H., Londquist, C.J., and Maurer, D.K., 1990, Ground-water resources of Honey Lake Valley, Lassen County, California, and Washoe County, Nevada: U.S. Geological Survey WaterResources Investigations Report 90-4050, 112 p.

Mitten, H.T., and Londquist, C.J., 1991, Documentation of model input and output values for the groundwater resources of Honey Lake Valley, Lassen County, California, and Washoe County, Nevada: U.S. Geological Survey Open-File Report 91-68, 4 p.

Rockwell, G.L., 1990, Surface-water hydrology of Honey Lake Valley, Lassen County, California, and Washoe County, Nevada: U.S. Geological Survey Open-File Report 90-177, scale 1:100,000, 2 sheets. 


\title{
RECLAIMED WATER USE, SAN DIEGO COUNTY
}

Number: CA399

\author{
Cooperating Agency: California Regional Water \\ Quality Control Board, San Diego Region
}

Project Chief: Lowell F.W. Duell, Jr.

Period of Project: July 1981 to February 1990

Problem: Most of San Diego County's water is imported. When the Central Arizona Project is completed, a major source of water will be reduced. To compensate for this loss, the San Diego Regional Water Quality Control Board wants to evaluate the groundwater basins as sites for wastewater reuse. Many logistical problems are associated with using reclaimed wastewater, such as the ambient quality of the ground water, storage capacity of the aquifer, quality of the reclaimed water, and soil suitability.

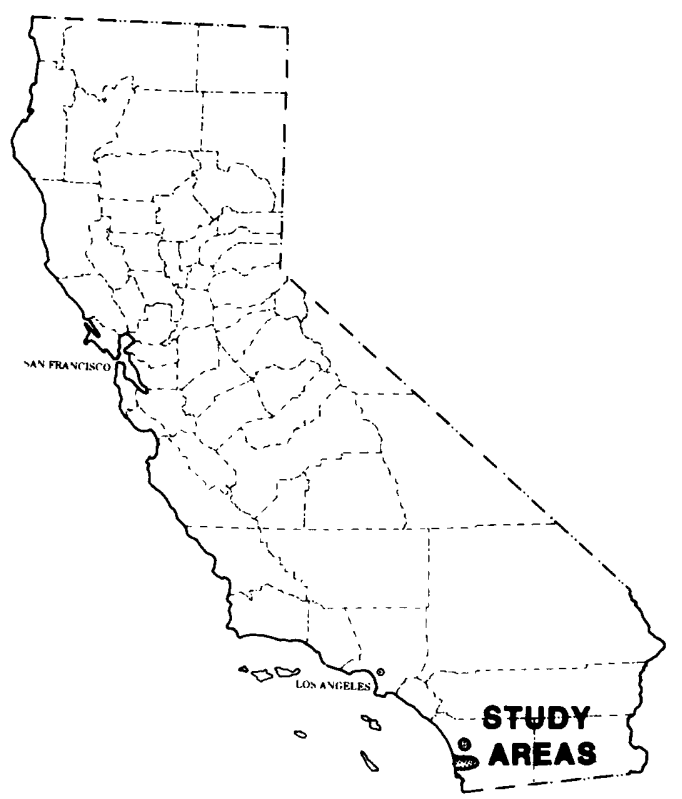

Objectives: Evaluate the ground-water and surface-water quantity and quality for selected hydrologic subareas. Samples will be collected and measurements made to provide a current data base. Evaluate the ability of each basin to accept reclaimed water. Define past, present, and future beneficial uses. Determine future plans of water purveyors, public agencies, and other water users concerning the use of reclaimed water. Assess the environmental impact of the use of reclaimed water on each subarea.

Approach: Background information and available ground-water data will be compiled. Wells will be inventoried to determine sampling locations. Data required to define quality and quantity will be collected. Water quality will be assessed and basin yield will be determined. Existing surface-water records will be compiled and data required to determine present and future water use and information on reclaimed water will be collected. The effect of reclaimed water recharge on ground-water quality will be assessed and percentage of water the recharge may replace will be determined. Potential uses of reclaimed water will be assessed.

\section{Progress:}

FY1988: Two subprojects were active during the year: an evaluation of water-quality conditions in the Escondido hydrologic subarea and a description of the water resources of the Descanso area. Data were analyzed and a report was written and reviewed. Data analysis included construction of land-use and precipitation bar charts, a current water-level map, and construction of historical and current water-quality maps. Water-level and water-quality data also were presented in tabular form. A study to evaluate the effect of future ground-water pumping in the Descanso area was done. Historical surface- and groundwater data were obtained and reviewed. Surface-water records were used to determine the seasonal variability in streamflow, and three water-quality samples were collected to determine the seasonal variability in chemical quality of the Sweetwater River streamgage near Descanso. Ten wells, spatially distributed and representing an area of current ground-water withdrawals, were sampled for chemical analyses to determine water quality. Results indicate that water quality in the area generally is good. Intermittent measurements of streamflow (25 sites) and water levels ( 25 wells) were made. Estimates of recharge will be made from streamflow losses and changes in ground-water levels. Specific yield obtained from a similar area (Lee Valley) will be used to estimate the quantity of ground water stored. Data collection was completed. 
FY1989: The report on the Escondido hydrologic subarea was completed and published. Hydrologic information was compiled for water year 1988 to evaluate the effects of current ground-water pumping on ground-water levels in the Descanso area in south-central San Diego County. During water year 1988, precipitation at the Descanso Ranger Station was 94 percent of normal, and discharge at Sweetwater River near Descanso was 98 percent of normal. The ground-water system in the Descanso area consists of aquifers in the consolidated bedrock (metamorphic and granitic rocks) and in the regolith (weathered bedrock). Most wells penetrate both aquifers, but the regolith is the source of most water pumped from wells.

Ground-water storage in 1988 was estimated at 800 to 2,000 acre-feet in the regolith and 300 to 3,000 acre-feet in the bedrock. Recharge to the ground-water system from infiltration of precipitation and streamflow was estimated to be 1,000 acre-feet during water year 1988. Pumpage in the Descanso area was estimated to be 170 acre-feet. Water levels in wells showed little change at the beginning and end of water year 1988, which suggests that ground-water pumping had little affect on ground-water storage.

Ground-water quality generally was suitable for domestic drinking water. Dissolved-solids concentrations in ground water from 10 wells in and near the Descanso area ranged from 247 to 424 milligrams per liter. Concentrations of iron and manganese, which are not toxic, commonly were present in concentrations that exceeded California maximum contaminant levels for domestic drinking water.

FY1990: A report on the water resources of the Descanso area was written and published.

Plans for Next Year: None. Project completed.

\section{Reports:}

Duell, L.F.W., Jr., 1990, Water resources of the Descanso area, San Diego County, California: U.S. Geological Survey Water-Resources Investigations Report 90-4014, 26 p.

Woolfenden, L.R., 1989, Geohydrology of the Escondido hydrologic subarea, San Diego County, California: U.S. Geological Survey Water-Resources Investigations Report 88-4223, 21 p. 


\section{TRANSPORT OF CONTAMINANTS FROM UNDERGROUND WASTEWATER DISPOSAL SYSTEMS, UPPER MOJAVE RIVER BASIN}

Number: CA400

Cooperating Agency: California State Water Resources Control Board

Project Chief: Amjad M.J. Umari

Period of Project: October 1987 to September 1990

Problem: In the upper Mojave River basin, wastewater from domestic and industrial septic tanks drains into seepage pits that allow the wastewater to readily percolate into the unsaturated zone. The possibility of contamination of ground water is a major concern because the underlying alluvial aquifer is the source of public water supply and because alternate sources of water are not available.

Objectives: (1) Investigate the role of the unsaturated zone in changing concentration and speciation of nitrogen from septic-tank wastewater; (2) investigate the role of the unsaturated zone in the transport of fecal bacteria from septic-tank wastewater; and (3) determine the potential for ground-water contamination from septic-tank wastewater.

Approach: Movement of septic-tank wastewater will be studied intensively at eight sites, which represent a range in geohydrologic conditions and septic-tank densities in the upper Mojave River basin. Rate of wastewater movement and changes of concentration of selected contaminants with depth in the unsaturated zone will be investigated at each site by utilizing hollow-stem augering, coring of soil samples, neutronmoisture probes, suction-cup lysimeters, and a variety of chemical and biological analyses of water and soil samples.

\section{Progress:}

FY1988: During April 1988, 14 boreholes were drilled in Apple Valley and Victorville. Some of these boreholes were for the emplacement of suction-cup lysimeters and some for the installation of neutronprobe access tubes. Four multiple-completion piezometers were constructed at one of the boreholes to study the quality of shallow ground water near the water table. The neutron-probe and lysimeter holes were drilled on residential lots as close as possible to the seepage pits. Cores were taken frequently during the hollow-stem auger drilling for the neutron-probe and lysimeter holes, and subsamples from the cores were analyzed for moisture content and microorganisms in a field laboratory. Water extracts from the cores were sent to the U.S. Geological Survey's Central Laboratory for water-quality analysis. The biological analyses of the cores indicated no high fecal coliform count, although the total bacteria count was high near the seepage-pit bottoms. Water-quality analyses of the cores and lysimeters indicated a decrease in nitrates with depth in the capillary zone; the decrease may be due to dilution or denitrification. Qualitative moisture-content profiles obtained from neutron-probe logs clearly indicated vertical migration of the sewage plume at newly constructed sites.

FY1989: A second drilling operation was completed during November 28-December 9, 1988. A lysimeter hole was drilled in Hesperia and instrumented with eight lysimeters. A new hole was drilled at one of the existing sites (Cheyenne-I) to monitor the shallow ground water and to study the attenuation of nitrates in a thin layer of the saturated zone directly under the water table. Microbiological analysis of cores from these two boreholes was shifted in focus to identify nitrate-reducing bacteria. Analyses showed the 
presence of nitrate-reducing bacteria in the cores at the same depths at which concentrations of nitrates decrease significantly. Water-quality samples also were extracted from the cores and sent to the Central Laboratory for analysis. An additional well with four multiple-completion piezometers was constructed in Apple Valley downgradient (along the direction of ground-water flow) from the previously constructed multiple-completion well and at a location such that the source of septic effluent exists between the two wells. Monthly collection and analysis of water samples from the lysimeters and bimonthly monitoring of the moisture-content profile by neutron-probe logging were continued. Grain-size analysis of the core samples also was continued.

FY1990: Final sampling of all active lysimeters in the study area was done, with the focus on obtaining samples to be analyzed for organic carbon and for nitrogen-isotope ratios (N15/N14), as part of an effort to document bacteria-mediated nitrate reduction. Some of the core samples obtained during the December 1988 drilling (and stored in a freezer) were thawed in January 1990, and porewater extracts from the samples were analyzed for chemical constituents. Grain-size analyses were done on those cores. Preparation of a final report was started.

Plans for Next Year: The final report will be written and reviewed.

\section{Reports:}

Umari, A.M.J., Martin, Peter, and Schroeder, R.A., 1989, Attenuation of nitrogen and fecal coliforms from septic-tank effluent through a thick unsaturated zone, upper Mojave River basin, California, in Pederson, G.L., and Smith, M.M., compilers, U.S. Geological Survey Second National Symposium on Water Quality: Abstracts of the Technical Sessions, Orlando, Florida, November 12-17, 1989: U.S. Geological Survey Open-File Report 89-409, p. 102. 


\section{ESTIMATING TIDAL AND RESIDUAL CIRCULATION IN SAN FRANCISCO BAY}

Number: CA419

Cooperating Agencies: California Department of Water Resources; and Califomia State Water Resources Control Board

Project Chief: Peter E. Smith

Period of Project: Continuing

Problem: California State and Federal water projects regulate the quantity of fresh water flowing into San Francisco Bay from the Sacramento-San Joaquin River Delta. The regulation has caused a decrease in the annual inflow of fresh water to the bay and has altered the time sequences of inflows during the year. The effect of decreased inflow may be altering the mixing characteristics of the bay and adversely affecting fish and shrimp populations.

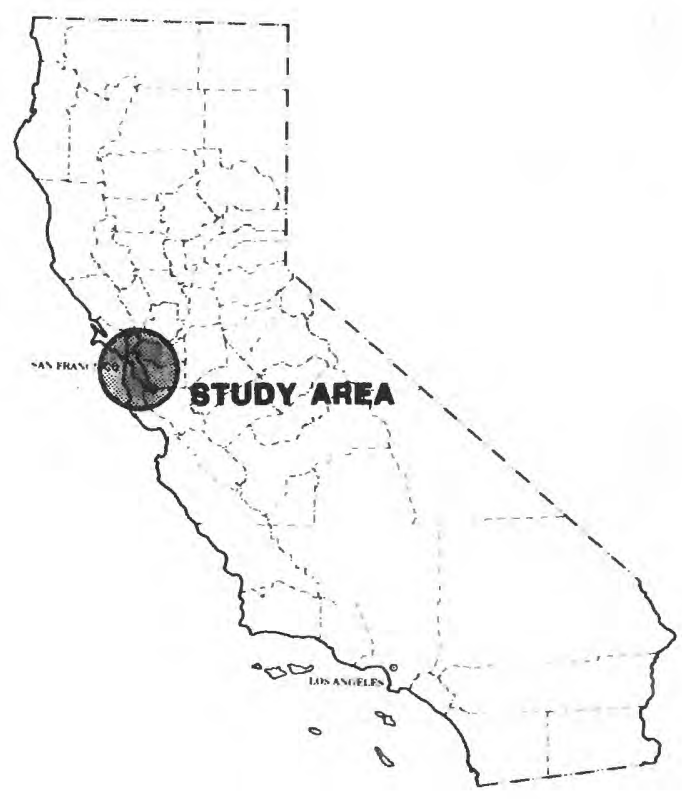

Objectives: To determine the magnitude and location of variations in hydrodynamics (water currents and salinity) within San Francisco Bay that result from changes in freshwater inflows from the Sacramento-San Joaquin River Delta.

Approach: Two- and three-dimensional mathematical models will be used to project the effect of variations in delta flows on water currents and salinity in the bay. In addition, currents and salinity will be measured during a wide range of delta-flow conditions. A new prototype of a vessel-mounted acoustic Doppler current profiling (ADCP) system will be tested and used to measure vertical profiles of currents. A high resolution in-situ conductivity-temperature-depth system will be used to measure vertical salinity profiles. Field data will be used as appropriate to calibrate and validate mathematical models.

\section{Progress:}

FY1988: Numerical modeling and field studies were continued. Calibration of the two-dimensional spectral model for the M2 tide was completed using data from about 70 current-meter records and 35 stage stations. The three-dimensional model was further refined through comparisons with velocity and salinity measurements in San Pablo Bay. The project personnel participated in State hearings throughout the autumn (1987) to set flow and salinity standards for the bay and delta. The hydrodynamic data base and data-management system were expanded to include current-meter data, shore salinity and water-level timeseries data, and meteorological data. Data from State agencies were obtained and entered into the data base. Four continuous-monitoring stations for water levels and one station for salinity were operated in the north bay throughout the year. In August and September, two new meteorological stations were installed on channel markers in San Pablo Bay. On March 25, 1988, an upward-looking ADCP was deployed at the west end of Carquinez Strait. In April and May, two 28-hour continuous field exercises were done to measure tidal flow near Chipps Island every 15 minutes over a complete tidal cycle.

FY1989: Numerical modeling and field studies were continued. A new fine-resolution grid for the spectral model was created with three times the number of grid points used in the previous model. The three-dimensional model of San Pablo Bay was modified to incorporate a mixing length turbulence model with Munk-Anderson formulas used to adjust the vertical distribution of mixing coefficients for the effects of density stratification. Calibration of the one-dimensional BRANCH model to the central delta was completed using more than 100 discharge measurements. The upward-looking ADCP, deployed in March 1988 at the west end of Carquinez Strait, was retrieved in January 1989 with about 8 months of good data. 
The data from the ADCP were analyzed with low-pass filters and animated on the IRIS workstation. Development was completed on a moving-boat system for measuring discharge with the vessel-mounted ADCP. Four continuous monitoring stations for water levels, one station for salinity, and two stations for meteorological data were operated in the north bay throughout the year. Two acoustic velocity meters were operated throughout the year on the Old and Middle Rivers in the delta.

FY1990: Two monitoring stations for water levels, one station for salinity, and two stations for meteorological data were operated in north bay throughout the year. Data collected from these stations, along with several years of historical salinity data from six additional monitoring stations, were reviewed and entered into a computerized hydrodynamic data base. Analyses of the monitoring data were begun using low-pass filters and principal-component analysis to study the causes of low-frequency variations in water levels and salinity. Hydrodynamic models continued to be developed and used in evaluating the effects of freshwater inflow on vertical and horizontal distributions of currents and salinity. A twodimensional finite-element transport model was programmed and tested for future use in modeling salinity. The model will be driven by simulations of currents obtained with a hydrodynamic spectral model that was developed and calibrated in earlier years of the study. A fully three-dimensional model was used in San Pablo Bay to simulate the vertical and lateral distribution of residual currents over six cross sections of the bay. The simulations showed residual currents are sensitive to freshwater inflow and tidal currents interacting with the complex bay bathymetry. Additional project accomplishments included the successful completion of a draft report describing an ADCP system and a sediment study in Carquinez Strait that involved collection of suspended-sediment samples over a tidal cycle and continuous measurement of currents with an upward-looking ADCP.

Plans for Next Year: Analyses of monitoring-station data and the three-dimensional modeling of San Pablo Bay will be continued. A field experiment for measuring currents and salinity in Carquinez Strait will be done during a 3-month period in winter.

Reports:

Burau, J.R., and Cheng, R.T., 1988, Predicting tidal currents in San Francisco Bay using a spectral model, in International Symposium on Model-Prototype Correlation: American Society of Civil Engineers, Hydraulics Division, Colorado Springs, Colorado, Proceedings, p. 634-639.

Burau, J.R., and Cheng, R.T., 1989, A general method for generating bathymetric data for hydrodynamic computer models: U.S. Geological Survey Open-File Report 89-28, 45 p.

Burau, J.R., and Cheng, R.T., 1989, A vertically averaged spectral model for tidal circulation in estuaries: Part 1. Model formulation: U.S. Geological Survey Water-Resources Investigations Report $88-4126,31 \mathrm{p}$.

Cheng, R.T., and Burau, J.R., 1988, System considerations in numerical modeling of estuarine problems: International Conference on Numerical Methods in Flow Problems, Okayama, Japan, September 4-8, Proceedings, 8 p.

Cheng, R.T., Burau, J.R. and Gartner, J.W., 1988, Interfacing data analysis and numerical modeling for tidal hydrodynamics phenomena, in International Conference on Tidal Hydrodynamics: Gaithersburg, Maryland.

Cheng, R.T., and Smith, P.E., 1990, A survey of three-dimensional numerical estuarine models: American Society of Civil Engineers, Estuarine and Coastal Modeling, Newport, Rhode Island, November 15-17, 1989, p. 1-15.

Gartner, J.W., and Yost, B.T., 1988, Tides, and tidal and residual currents in Suisun and San Pablo Bays, California, results of measurements, 1986: U.S. Geological Survey Water-Resources Investigations Report 88-4027, 94 p.

Oltmann, R.N., Burau, J.R., and Simpson, M.R., 1990, Use of a acoustic Doppler current profiler (ADCP) to measure velocity profiles and discharge: Poster session, Interagency workshop on the Hydrodynamics Study of San Francisco Bay, January, Asilomar, California.

Simpson, M.R., and Oltmann, R.N., 1990, An acoustic Doppler discharge-measurement system: American Society of Civil Engineers, Hydraulic Engineering, San Diego, California, Proceedings, p. 903-908. 
Smith, L.H., 1990, Sub-tidal salinity variations in San Francisco Bay, California: Eos, Transactions of the American Geophysical Union, Abstracts, v. 71, no. 43, p. 1356-1357.

Smith, P.E., 1990, Practical considerations in modeling the three-dimensional circulation and salinity in San Pablo Bay, California: American Society of Civil Engineers, Hydraulic Engineering, San Diego, California, Proceedings.

Smith, P.E., and Cheng, R.T., 1990, Recent progress on hydrodynamic modeling of San Francisco Bay, California: American Society of Civil Engineers, Estuarine and Coastal Modeling, Newport, Rhode Island, November 15-17, 1989, Proceedings, p. 502-510.

Smith, P.E., and Larock, B.E., 1989, High-resolution two-dimensional advective transport: American Society of Civil Engineers, National Conference on Hydraulic Engineering, New Orleans, Louisiana, August 14-18, Proceedings, p. 1005-1010.

Taylor, M.J., and Yost, B.T., 1990, Description of salinity, temperature, chlorophyll, suspended-sediment, and velocity data, south San Francisco Bay, California, February-April 1987: U.S. Geological Survey Open-File Report 89-619, 28 p. 


\section{SOUTHERN CALIFORNIA REGIONAL AQUIFER-SYSTEM ANALYSIS}

Number: CA424

Cooperating Agency: None. (U.S. Geological Survey Federal Program)

Project Chief: Peter Martin

Period of Project: October 1990 to September 1994 (reactivated)

Problem: To meet the needs for hydrologic information on a regional scale and to develop predictive capabilities to effectively manage the Nation's ground-water resources, the U.S. Geological Survey has initiated a series of hydrologic investigations in the Regional Aquifer Systems Analysis (RASA) program. This study of ground water in coastal and desert basins in southern California is a part of the RASA program. Annual ground-water pumpage in the study area is about 2.6 million acre-feet. The water is used primarily for agricultural and domestic supplies. About 2.3 million acre-

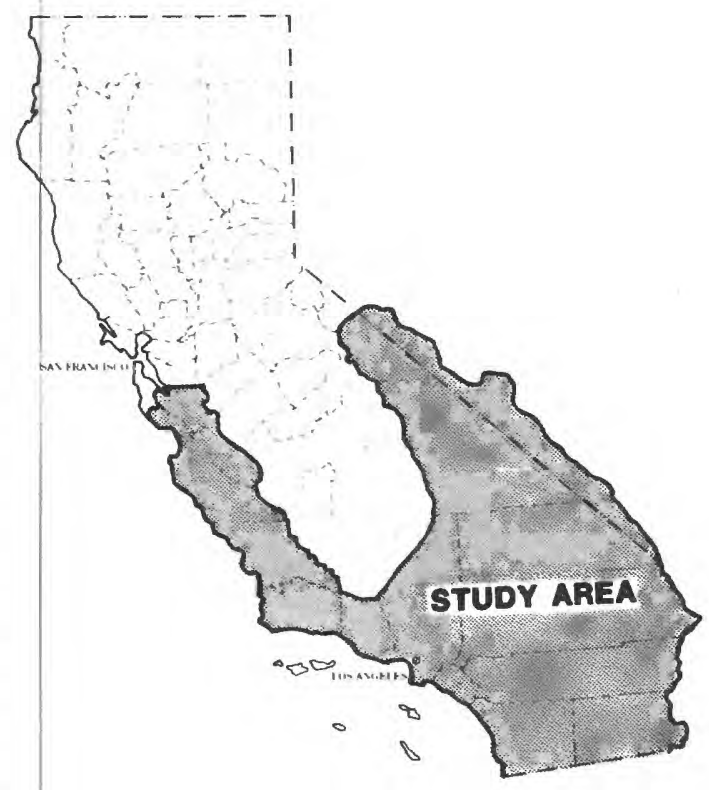
feet per year is pumped from the coastal basins where salt-water intrusion and degradation of ground-water quality are common problems. About 0.3 million acre-feet per year is pumped from desert basins where the problems are the relatively small rates of natural recharge and naturally occurring high concentrations of fluoride, boron, sulfate, and dissolved solids.

Objectives: Define the hydrologic and geochemical characteristics of ground-water basins. Determine the chemical quality of water including sources of contamination. Determine the available ground-water storage and the rates of depletion. Estimate when serious reductions in yield may begin to occur in the basins. Evaluate alternative methods for extending the life of ground-water basins; (6) estimate the effects of future pumping on water quality including salt-water intrusion. Define the role of ground water during extreme hydrologic conditions, such as drought, and its usefulness as a source of emergency water supply.

Approach: The first phase of the study will identify all existing and pertinent hydrologic information and will identify areas where there are critical data gaps. Within the first 18 months, a bibliography containing about 4,000 entries will be prepared. Within this same time, maps will be prepared from existing data that show: (1) Current land and ground-water uses; (2) documented ground-water problems and issues; (3) the geohydrologic framework including basin boundaries and aquifer characteristics and thicknesses; (4) water levels and directions of ground-water movement; (5) dissolved-solids concentrations; and (6) areas and rates of pumpage, artificial recharge, and ground-water depletion. The second phase of the study will include data collection and modeling where necessary to better gain knowledge and to report on the: (1) geohydrologic framework; (2) geochemistry and water-quality problems; (3) hydraulics of seawater intrusion; and (4) ground-water use including hydraulic and economic optimization of management alternatives.

Progress:

FY1990: The study was reactivated in fiscal year 1990 after a 4-year suspension. A map report describing the deuterium content of water from wells and perennial springs in southeastern California was completed and approved for publication. The Santa Clara-Calleguas coastal basin was selected for intensive analysis of the major issues and problems affecting ground-water use in southern California. Available hydrologic data were compiled and input into a geographic information system (GIS). A surface resistivity study was completed to help determine the inland extent of seawater intrusion into the basin. 
Several multidepth observation wells were constructed to better define the geohydrology of the basin and to collect water-level and water-quality data from the different aquifers. An initial two-layer groundwater-flow model was developed for the basin.

Plans for Next Year: A four-layer ground-water-flow model for the Santa Clara-Calleguas basin will be developed and calibrated. Basin hydraulic characteristics and water-quality data will be analyzed to determine the natural geohydrologic and human activities that affect the rate of seawater intrusion. Solutetransport models will be developed to gain knowledge of the movement of the seawater-intrusion front. The geochemistry of ground water in the different aquifers will be analyzed. A representative desert basin also will be selected for intensive study. Available (and additional collected) hydrologic data will be input into a geographic information system, and a ground-water-flow model will be developed.

Reports: None 


\section{CENTRAL VALLEY REGIONAL AQUIFER-SYSTEM ANALYSIS}

Number: CA428

\section{Cooperating Agency: None. (U.S. Geological Survey Federal Program)}

\section{Project Chief: Neil M. Dubrovsky}

\section{Period of Project: October 1985 to September 1990}

Problem: Selenium and other elements have been measured in concentrations that exceed recommended levels in agricultural return water and sediments from the San Luis Drain. It is unknown if these problems include the deep aquifer as well as the shallow one. Other unknowns include the degree of natural or artificial leakage through the confining clay layer and the geochemical processes controlling water chemistry in San Joaquin Valley aquifers.

Objectives: Assess the distribution of major ions, trace elements, and pesticides in zones of fresh water in the regional aquifers. Evaluate historical changes in ground-water chemistry due to increased recharge due to irrigation and overdrafts caused by pumping for irrigation. Determine the regionally important geochemical processes that control trace-element concentrations in the ground water, and thus explain their present distribution. Evaluate key hydrologic and pesticide-use factors that affect the degree of contamination of water-table aquifers.

Approach: Existing wells throughout the valley will be inventoried and sampled. New, multiple-depth sampling wells will be selectively installed. Trace elements and major ions will be assessed throughout and pesticides will be assessed in the water-table aquifer.

\section{Progress:}

FY1988: Work progressed on the installation of the 2-dimensional profiles along the Panoche (P), Murietta $(\mathrm{M})$, and Firebaugh $(\mathrm{F})$ flow lines. A preliminary evaluation of the data was made, specific gaps in the data were identified, and several wells were installed. The preliminary evaluation was included in a comprehensive report on the occurrence and transport of selenium in the western San Joaquin Valley. Selected findings also were presented at the American Geophysical Union 1988 Spring Meeting in Baltimore, Maryland. Additional detailed sampling took place at the most basinward site in the P profile, P1. Preliminary analysis of the 1987 data at P1 indicated that selenium mobility may be limited owing to low redox potentials in the ground water at this site. Two studies were designed to investigate the occurrence and mobility of pesticides in two common San Joaquin Valley settings. One study will examine the mobility of pesticides in a typical west-side cotton field, and the other will investigate the transport of triazine herbicides and dinoseb in vineyards and orchards on the east side of the valley. Fieldwork on the mobility of pesticides was started. Eleven wells were installed at sites in the Lost Hills area in southwestern San Joaquin Valley. Spacing of screened intervals was selected by sampling porewater at 20-foot intervals, measuring specific conductance, and using the specific-conductance data to guide subsequent drilling.

FY1989: Installation and sampling of observation wells were completed for the 2-dimensional profiles of ground-water chemistry on the Panoche $(P)$ and Murietta $(M)$ flow lines. A final report on the interpretation of the data from these wells was in preparation. A detailed evaluation of the influence of redox potential on selenium transport in ground water at the most basin-ward site of the P profile was 
presented at the American Geophysical Union 1988 winter meeting in San Francisco. An additional experiment at this site studied the in-situ reduction of selenate by injecting a known mass of high-selenate water labeled with a conservative tracer and then sampling the injected solution for 6 weeks. One additional set of observation wells was installed in the Lost Hills area to extend the profile into flood-basin sediments past the toe of the alluvial-fan deposits. Well installation was completed at eight sites in the eastem San Joaquin Valley where the transport of triazine herbicides is being studied. These wells were sampled once, and a second sampling was in progress at the end of the fiscal year.

FY1990: Work progressed on the completion of reports on the valley-wide and site-specific investigations of trace-element and pesticide occurrence in ground water in San Joaquin Valley. An evaluation of the selenium distribution along three 2-dimensional profiles ( $P, M$, and $F$ ) of ground-water chemistry in the westem part of the valley was summarized in a compilation of selenium-related research. Preparation of a final report was started. The data show that the highest selenium concentrations are in young, recently recharged ground water with high salinity at shallow depths in the regional aquifer. A report evaluating the influence of redox potential on selenium transport at the most basinward site in the P profile was published. The investigation showed that transport of selenium from Coast Ranges deposits, in which oxidizing conditions occur, into more reduced Sierra Nevada deposits is limited by microbially mediated reduction of selenate to less mobile species. The results of the valleywide sampling of existing wells for selenium were reported at the National Meeting of the Association of Ground Water Scientists and Engineers on September 26, 1990, in Anaheim, California. Extractions were done on samples from a soil profile to further evaluate factors affecting transport of triazine herbicides at a site in the eastern San Joaquin Valley where ground water already has been sampled.

Plans for Next Year: Final reports will be completed and published.

Reports:

Deverel, S.J., 1988, Geohydrologic aspects of water-quality problems of the San Joaquin Valley, California: American Society of Civil Engineers, National Irrigation and Drainage Division Conference on Planning Now for Irrigation and Drainage, Lincoln, Nebraska, July 18-21, Proceedings, p. 694-699.

Deverel, S.J., 1989, Geostatistical and principal-component analyses of groundwater chemistry and soil-salinity data, San Joaquin Valley, California, in Stephen Ragone, ed., Regional characterization of water quality: International Association of Hydrologic Sciences, Publication No. 182 , p. $11-18$.

Deverel, S.J., 1990, Distribution and mobility of trace constituents associated with irrigated agriculture in the Western United States (abs.): American Association for the Advancement of Science, Pacific Division, 71st, Davis, California, v. 9, part 1, p. 33.

Deverel, S.J., and Bell, R.B., 1988, Carbon mass transfer and isotopic evolution in shallow ground water, San Joaquin Valley, California: Eos, Transactions of the American Geophysical Union, Abstracts, v. 69 , no. 44 , p. 1194.

Deverel, S.J., and Fio, J.L., 1989, Application of oxygen-18 and deuterium data to the understanding of selenium transport to agricultural drainage systems, San Joaquin Valley, California: Eos, Transactions of the American Geophysical Union, Abstracts, v. 70, no. 43, p. 1382.

Deverel, S.J., and Fio, J.L., 1990, Ground-water flow and solute movement to drain laterals, western San Joaquin Valley, California. 1. Geochemical assessment: U.S. Geological Survey Open-File Report 90-136, 23 p.

Deverel, S.J., and Fujii, Roger, 1988, Processes affecting the distribution of selenium in shallow groundwater of agricultural areas, western San Joaquin Valley, California: Water Resources Research, v. 24 , no. 4 , p. $516-524$.

Deverel, S.J., and Fujii, Roger, 1990, Chemistry of trace elements in soils and ground water, chap. 4 in Tanji, K.K., ed., Agricultural salinity assessment and management: American Society of Civil Engineers Manuals and Reports on Engineering Practice No. 71, p. 64-90.

Deverel, S.J., and Gallanthine, S.K., 1989, Relation of salinity and selenium in shallow groundwater to hydrologic and geochemical processes, western San Joaquin Valley, California: Journal of Hydrology, v. 109, p. 125-149. 
Deverel, S.J., and Millard, S.P., 1988, Distribution and mobility of selenium and other trace elements in shallow groundwater of the western San Joaquin Valley, California: Environmental Science and Technology, v. 22, no. 6, p. 697-702.

Dubrovsky, N.M., and Neil, J.M., 1988, Processes that control selenium distribution in ground water, western San Joaquin Valley, California: Eos, Transactions of the American Geophysical Union, Abstracts, v. 69, no. 16, p. 364.

Dubrovsky, N.M., Neil, J.M., and Fujii, Roger, 1988, Possible redox control of selenium transport in a complex stratigraphic setting in the San Joaquin Valley, California: Eos, Transactions of the American Geophysical Union, Abstracts, v. 69, no. 44, p. 1181.

Dubrovsky, N.M., Neil, J.M., Fujii, Roger, Oremland, R.S., and Hollibaugh, J.T., 1990, Influence of redox potential on selenium distribution in ground water, Mendota, western San Joaquin Valley, California: U.S. Geological Survey Open-File Report 90-138, 24 p.

Fio, J.L., and Deverel, S.J., 1988, Ground-water flow to subsurface agricultural drains in the western San Joaquin Valley, California: Eos, Transactions of the American Geophysical Union, Abstracts, v. 69 , no. 44 , p. 1188 .

Fio, J.L., and Deverel, S.J., 1989, Ground-water flow to subsurface agricultural drains in the western San Joaquin Valley, California, in Pederson, G.L., and Smith, M.M., compilers, U.S. Geological Survey Second National Symposium on Water Quality: Abstracts of the Technical Sessions, Orlando, Florida, November 17-19: U.S. Geological Survey Open-File Report 89-409, p. 25.

Fio, J.L., and Deverel, S.J., 1990, Ground-water flow and solute movement to drain laterals, western San Joaquin Valley, California. 2. Quantitative hydrologic assessment: U.S. Geological Survey Open-File Report 90-137, 15 p.

Fio, J.L., and Deverel, S.J., 1990, Interaction of shallow ground water and subsurface drains: Implications for selenium transport and distribution in the western San Joaquin Valley, California: Ground Water, v. 28 , no. 5 , p. $788-789$.

Fio, J.L., and Fujii, Roger, 1990, Selenium speciation methods and application to soil saturation extracts from San Joaquin Valley, California: Soil Science Society of America Journal, v. 54, no. 2, p. 363-369.

Fio, J.L., Fujii, Roger, and Deverel, S.J., 1990, Evaluation of selenium mobility in soil using sorption experiments and a numerical model, western San Joaquin Valley, California: U.S. Geological Survey Open-File Report 90-135, 13 p.

Fujii, Roger, 1988, Speciation of soluble and adsorbed selenium in soils, western San Joaquin Valley, California: Eos, Transactions of the American Geophysical Union, Abstracts, v. 69, no. 44, p. 1182.

Fujii, Roger, 1989, Speciation of soluble and adsorbed selenium in soils, western San Joaquin Valley, California, in Pederson, G.L., and Smith, M.M., compilers, U.S. Geological Survey Second National Symposium on Water Quality: Abstracts of the Technical Sessions, Orlando, Florida, November 17-19: U.S. Geological Survey Open-File Report 89-409, p. 28.

Fujii, Roger, and Burau, R.G., 1989, Estimation of adsorbed Se(IV) in soils, westem San Joaquin Valley, California: Ameerican Society of Agronomy, Annual Meeting, Las Vegas, Nevada, Agronomy Abstracts, December, p. 200.

Fujii, Roger, and Fio, J.L., 1988, Partitioning and speciation of soluble and adsorbed selenium in soils (abs.): American Society of Agronomy, 80th Annual Meeting, Anaheim, California, Agronomy Abstracts, November 27-December 2, p. 197-198.

Fujii, Roger, and Lipton, D.S., 1990, Mobility and solid-phase distribution of selenium in soils, western San Joaquin Valley, California (abs.): American Association for the Advancement of Science, Pacific Division, 71st, Davis, California, v. 9, part 1, p. 36.

Gilliom, R.J., 1989, Selenium in the San Joaquin Valley: Sources, distribution, and mobility: U.S. Geological Survey Yearbook, Fiscal Year 1988, p. 30-34.

Gilliom, R.J., and others, 1989, Preliminary assessment of sources, distribution, and mobility of selenium in the San Joaquin Valley, California: U.S. Geological Survey Water-Resources Investigations Report 88-4186, 129 p.

Gronberg, J.M., Belitz, Kenneth, and Phillips, S.P., 1990, Distribution of wells in the central part of the western San Joaquin Valley, California: U.S. Geological Survey Water-Resources Investigations Report 89-4158, 51 p. 
Heimes, F.J., Gronberg, J.M., and Carlson, J.R., 1988, Applications of a geographic information system to hydrologic studies in the San Joaquin Valley, California: GIS Symposium, National Academy of Science, Denver, Colorado, September 25-30, 2 p.

Neil, J.M., and Beard, Sherrill, 1988, Stratigraphy and mineralogy at the transition between oxidizing and reducing sediments in the San Joaquin Valley, California: Eos, Transactions of the American Geophysical Union, Abstracts, v. 69, no. 44, p. 1181.

Phillips, S.P., and Belitz, Kenneth, 1988, Calibration of a texture-based model of a ground-water flow system, western San Joaquin Valley, California: Eos, Transactions of the American Geophysical Union, Abstracts, v. 69, no. 44, p. 1188.

Phillips, S.P., and Belitz, Kenneth, 1990, Calibration of a texture-based model of a ground-water flow system, western San Joaquin Valley, Califomia: U.S. Geological Survey Open-File Report 90-573, $30 \mathrm{p}$.

Shelton, L.R., 1989, Improved sampling methods for organic constituents, in Pederson, G.L., and Smith, M.M., compilers, U.S. Geological Survey Second National Symposium on Water Quality: Abstracts of the Technical Sessions, Orlando, Florida, November 17-19: U.S. Geological Survey Open-File Report 89-409, p. 89.

Shelton, L.R., and Miller, L.K., 1988, Water-quality data, San Joaquin Valley, California, March 1985 to March 1987: U.S. Geological Survey Open-File Report 88-479, 210 p. 


\section{SALTWATER INTRUSION AT SANTA BARBARA}

Number: CA429

Cooperating Agency: Santa Barbara, city of

Project Chief: Peter Martin

Period of Project: October 1985 to September 1989

Problem: Saltwater intrusion into freshwater aquifers is a major problem in the coastal basins of southern California. Many wells in the coastal basins have been abandoned because of intrusion. Extensive intrusion in some basins has led to the use of injection wells to create freshwater barriers to retard further intrusion. Effective management of the water resources of the region requires greater understanding of the ground-water hydraulics, and the usefulness of computer solute-transport models on saltwater-intrusion problems needs to be evaluated.

Objectives: Determine the extent of saltwater intrusion into Storage Unit 1 of the Santa Barbara ground-water basin. Develop a model to simulate the movement of saltwater into the freshwater aquifer.

Approach: A series of wells will be drilled and constructed at varying depths in a line perpendicular to the coastline to determine the lateral and vertical distribution of saltwater in the freshwater aquifer and to determine aquifer hydraulic characteristics. Chloride concentrations and water levels will be monitored monthly at the observation wells during the first two years of the study in order to track the intrusion during major summer pumping periods. A cross-sectional solute-transport model will be calibrated and used to simulate the movement of saltwater into the freshwater aquifer.

\section{Progress:}

FY1988: Chloride concentrations were analyzed bimonthly and water levels were measured monthly at 13 observation wells completed at varying depths along the coastline. Ground-water pumping from Storage Unit I was reduced significantly below the annual rate of recharge to the basin. As a result of the reduction in pumping, water levels rose above sea level throughout Storage Unit I, and chloride concentrations in water samples from most of the coastal observation wells decreased significantly in comparison with water samples collected in 1987. Work was started on the development and calibration of a solute-transport model to simulate the measured movement of saltwater into the freshwater aquifer.

FY1989: Bimonthly analysis of chloride concentration and monthly measurements of water levels at the 13 observation wells were continued. The solute model was calibrated to steady- and transient-state conditions. Steady-state conditions were simulated by setting the initial pressures and solute concentrations to zero and running the model until the saltwedge moved inland and stabilized. The model then was used to simulate measured monthly pumpage during 1947-88. Initial model results indicated that the model code did not adequately model the variations in storage coefficient present along the cross section. The code subsequently was modified to allow specific storage to be input at each mode. A significant result of the initial model runs is the necessity to model the offshore fault as a low-conductance barrier in order to simulate measured solute concentrations. Model runs in which the fault conductance was 0.0 (no flow) or 1.0 (unrestricted flow) did not come close to matching measured concentrations. 
FY1990: Model calibration was completed. Model runs were made to simulate the movement of saltwater in response to different levels of pumping.

Plans for Next Year: A report will be written describing the results of water-level and water-quality monitoring and calibration of the solute-transport model.

Reports: None. 


\title{
HYDROLOGIC STUDIES RELATED TO VOLCANIC ACTIVITY IN LONG VALLEY
}

\author{
Number: CA431
}

Cooperating Agency: None. (U.S. Geological Survey Federal Program)

Project Chief: Christopher D. Farrar

Period of Project: Continuing

Problem: Long Valley along the eastern Sierra Nevada frontal fault is part of a large volcanic depression called the Long Valley caldera. Since 1978, earthquake activity has increased in the caldera. This earthquake activity and a total uplift of 31 centimeters probably are a result of rising magma. On May 26, 1982, the U.S. Geological Survey issued a notice of potential volcanic hazard in the Long Valley area. In response to this notice, the Survey has taken the lead in studies that include monitoring, assessment of potential hazards, and research for methods of prediction.

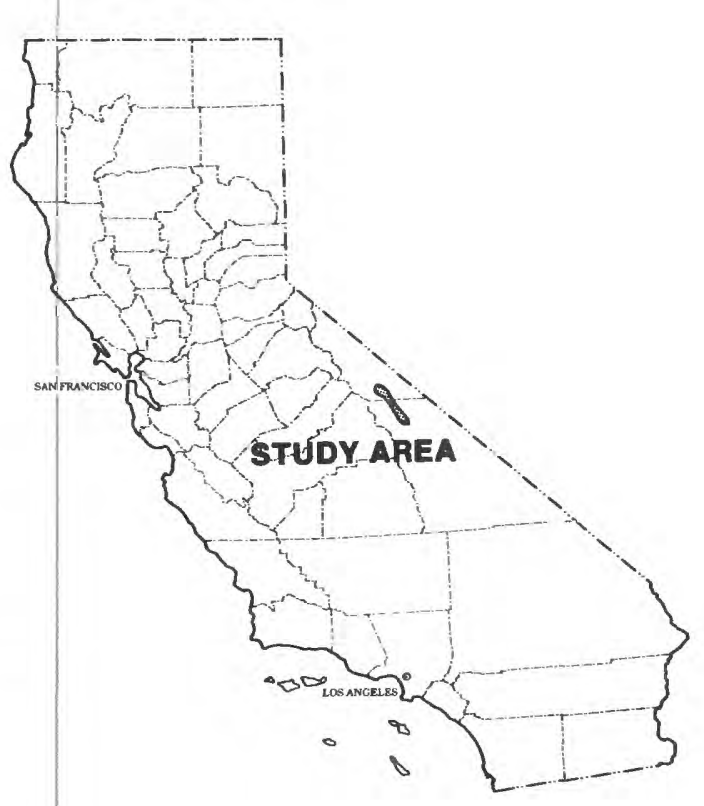

Objectives: The project is divided into three phases with the following objectives: Phase 1--Monitor ground water and surface water to detect changes in the hydrologic system caused by geologic processes and phenomena associated with volcanism or with magma at depth in Long Valley caldera. Phase 2--Determine the flood discharge at selected locations, depth of flow extent of inundation, and time of travel of flood wave following project failure of Long Valley Dam (Lake Crowley) on Owens River. Phase 3--Delineate type and magnitude of changes that would be expected in the ground-water system of Long Valley caldera prior to volcanic eruption.

Approach: Phase 1--Operate a network to monitor ground-water levels, water temperature and water quality, and surface-water quality. Relate data to geologic events. Phase 2--Apply General Purpose Dam-Break Flood Simulation Model (K-634) for a projected dam failure. Application of other models or development of a new diffusion model will be considered. Phase 3--Develop quantitative models capable of analyzing the interactions that take place between water-saturated rock and magmatic intrusions.

\section{Progress:}

FY1988: Hydrologic data were collected from a monitoring network that includes: continuous recording of ground-water levels and atmospheric pressure at six sites; continuous recording of spring flow at two sites; continuous discharge, temperature, and specific conductance recording at one stream site; triennial ground-water-level measurements in a network of 40 wells; and chemical and isotopic samples from 15 sites. Data for 1986 were compiled in a water-resources investigations report, and the report was submitted for Regional review. Data collected in 1987 and 1988 will be released in a report describing hydrologic changes during 1982-88. Significant seismicity has not occurred within or in close proximity to the Long Valley caldera since the Chalfant Valley earthquakes of July 1986. Crustal deformation is waning, although extension in the western moat is still detectable with geodetic instruments and through analysis of ground-water-level fluctuations in key wells. The decline of ground-water levels in deep aquifers (by as much as 4 feet) may be related to below normal recharge during the past 2 years or to geothermal exploitation. 
FY1989: Hydrologic data were collected from a monitoring network that includes: water-level measurements (50 wells), ground-water levels ( 3 wells), atmospheric pressure ( 3 sites), discharge ( 2 thermal springs), stage (1 surface-water site), chemical and isotopic samples (12 sites). Changes in thermal spring activity in Hot Creek gorge increased following a low energy seismic swarm during September 1988. These changes were tracked monthly by plotting locations of active vents on a detailed base map, recording temperatures, and making qualitative estimates of liquid and gas discharge rates. Total thermal water discharge calculated by monthly measurements of boron and chloride fluxes did not significantly increase in Hot Creek gorge compared to earlier years. A second area of seismic swarm activity has been centered under Mammoth Mountain since April 1989. The temperature of a gas vent high on the flank of Mammoth Mountain was about $5{ }^{\circ} \mathrm{C}$ higher than 3 years earlier, however, gas chemistry and helium $3 / 4$ ratio were unchanged in a sample collected in July 1989. Crustal deformation continues in the caldera but at diminishing rates. Extension rates in the west moat detected by water-level fluctuations in two key wells are consistent with extension detected by a down-hole dilatometer. Minor changes in the characteristics of thermal springs at Casa Diablo were noted; however, these changes probably are the result of fluid production and injection at a geothermal electric powerplant.

FY1990: Hydrologic data were collected from a monitoring network that includes: recording groundwater levels and atmospheric pressure at three sites, recording discharge from two thermal springs, recording stage at one surface-water site, triennial water-level measurements in a network of 50 wells, and chemical and isotopic analysis of water from 12 sites. Changes in the locations and volumes of thermal fluid discharge from springs in Hot Creek gorge continued through 1990. Changes in spring vent locations and fluid pressures probably are related to changes in macropermeability in near-surface rocks caused by frequent seismicity near Hot Creek gorge. Monthly measurements of boron and chloride fluxes, used to calculate total thermal water discharge and show no significant increase in the total volume of thermal water discharged in Hot Creek gorge compared to earlier years. A second area of seismic swarm activity has been centered under Mammoth Mountain. A data logger was deployed at a fumarole on the mountain to record vent gas temperature and air temperature and pressure. The vent gas temperature is about $5^{\circ}$ hotter than in 1982. Gas samples were collected from this vent on five occasions since July 1989. The helium $3 / 4$ ratio shows an increase to $5.9(\mathrm{Rs} / \mathrm{Ra})$ from 3.7 in 1982 . This increase is interpreted to result from an increase in the magmatic gas contribution caused by crustal deformation associated with a postulated shallow dike injection.

Plans for Next Year: Data collection from a monitoring network of eight recording sites will continue through 1991. Sampling from Mammoth Mountain fumarole will continue to determine the relation of magnitude and timing of changes in gas composition to local seismicity. A more accurate pressure sensing system is now ready for installation in a 1,300-foot deep well located in the area of maximum crustal deformation. Ground-water-level fluctuations will be interpreted in terms of strain in the aquifer. Aerial infra-red surveys will be made to detect future changes in thermal discharge.

\section{Reports:}

Farrar, C.D., and Lyster, D.L., 1990, Monitoring the hydrologic system for potential effects of geothermal and ground-water development in the Long Valley caldera, Mono County, California, U.S.A.: Geothermal Resources Council, 1990 International Symposium on Geothermal Energy, Kailua Kona, Hawaii, August 20-24, Transactions, v. 14, part 1, p. 669-674.

Farrar, C.D., Sorey, M.L., Rojstaczer, S.A., Steinemann, A.C., and Clark, M.D., 1989, Hydrologic and geochemical monitoring in Long Valley caldera, Mono County, California, 1986: U.S. Geological Survey Water-Resources Investigations Report 89-4033, 69 p. 


\section{IRRIGATION DRAINAGE FIELD-SCREENING STUDY OF SACRAMENTO REFUGE COMPLEX}

Number: CA453

Cooperating Agency: U.S. Department of the Interior

Project Chief: Peter D. Dileanis

Period of Project: October 1987 to September 1989

Problem: Drainage from irrigated agricultural operations have caused a contamination problem at or near several Federally operated wildlife refuges. Agricultural return flows often contain contaminants, such as pesticides and trace elements, which have known impacts on biota. The operation of many wildlife refuges requires the use of some agricultural return flows, which often is the only source of water for the refuge. Continued use of these waters may jeopardize the use of the refuges for wildlife.

Objectives: Determine whether irrigation drain water has caused or has the potential to cause harmful effects on human health, fish and wildlife, and other beneficial water uses in the study area.

Approach: Each of the five refuges in the Sacramento Refuge complex will be sampled once during 1988 at a time when contamination is most likely to occur. Wildfowl, invertebrates, plant material, and water (rice herbicide analysis only) will be sampled in late April to early May 1988. Water, bottom material, and biological samples to be analyzed for pesticides and trace elements will be collected in early September 1988 to coincide with rice field drainage. Data will be analyzed during 1989.

\section{Progress:}

FY1988: All water, bottom material, and biological samples were collected and sent to U.S. Geological Survey and U.S. Fish and Wildlife Service laboratories for analysis. Preliminary work was started on a water-resources investigations report that will summarize the findings of this study.

FY1989: Chemical analyses of samples sent to the U.S. Geological Survey and the U.S. Fish and Wildlife Service laboratories were received in June. A large part of the summary report was prepared.

FY1990: All sections of the final report were received from the contributing authors and a first draft of the final report was completed.

Plans for Next Year: The water-resources investigation report titled "Reconnaissance investigation of water quality, bottom sediment, and biota associated with irrigation drainage in the Sacramento Valley, California," will be completed and published.

Reports: None. 


\section{WESTERN SAN JOAQUIN VALLEY HYDROLOGIC STUDIES}

Number: CA456

Cooperating Agency: U.S. Department of the Interior, Bureau of Reclamation

Project Chief: Robert J. Gilliom

Period of Project: October 1984 to September 1990

Problem: Shallow ground water in the highly productive agricultural area of the western San Joaquin Valley contains high concentrations of several potentially toxic trace elements, particularly selenium. Some of this water has been artificially drained to surface waters, where adverse effects on waterfowl have been observed. The area of contaminated ground water is extensive, and the potential effects on surface- and ground-water quality by continued irrigation and drainage discharge is considerable.

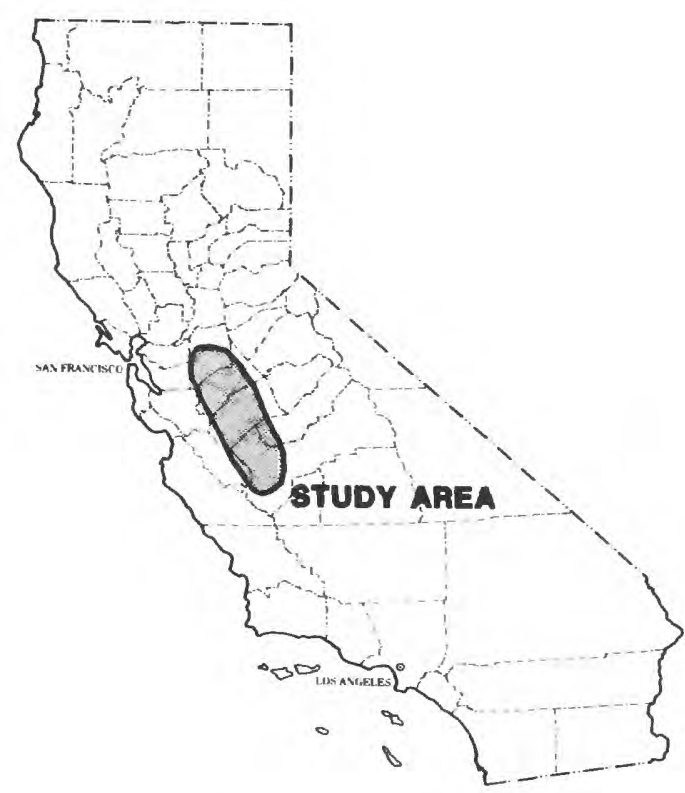

Objectives: Conduct a comprehensive hydrogeologic and geochemical study of the sources, distribution, movement, and fate of selenium and other trace elements in the hydrologic system of the western San Joaquin Valley.

Approach: An integrated series of laboratory and field studies will be done including (1) extensive sampling of soils, ground water, and the San Joaquin River system; (2) laboratory studies of trace-element geochemistry; and (3) monitoring of ground-water flow and solute transport.

\section{Progress:}

FY1988: Selected fieldwork and laboratory analyses were continued. Numerous reports were published. Results from the study of the distribution of selenium in soils and ground water reveal that, on a regional scale, leaching by irrigation, natural distribution of soil salinity, and evaporation from a shallow water table are the most important processes that have affected the present-day distribution. At a local farmdrainage scale, displacement of evaporated water towards drain laterals is the most important process affecting the distribution. Considerable progress was made in the study of geochemical processes in characterizing total soluble and phosphate-extractable selenium concentrations in various near-surface soils from the Panoche alluvial fan area. A quasi-three-dimensional flow model was the primary tool of analysis used to understand the ground-water-flow system of the study area. Steady-state calibration of the model for transmissivity and leakance basically was completed. Hydraulic properties of the system were quantified for slug tests at about 200 wells. Preliminary results of the transport study of the San Joaquin River show that the river delivers two to three times the selenium load to the delta in comparison with the Sacramento River. Selenate is the predominant form of selenium in both rivers.

FY1989: All fieldwork was completed and several reports were published, including a preliminary summary of study results.

FY1990: Final reports were prepared for publication.

Plans for Next Year: None. Project completed. 
Reports:

Clifton, D.G., and Gilliom, R.J., 1989, Sources and concentrations of dissolved solids and selenium in the San Joaquin River and its tributaries, California, October 1985 to March 1987: U.S. Geological Survey Water-Resources Investigations Report 88-4217, 33 p.

Clifton, D.G., and Gilliom, R.J., 1989, Trace elements in bed sediments of the San Joaquin River and its tributary streams, California, 1985: U.S. Geological Survey Water-Resources Investigations Report 88-4169, 33 p.

Deverel, S.J., 1988, Geohydrologic aspects of water-quality problems of the San Joaquin Valley, California: American Society of Civil Engineers, National Irrigation and Drainage Division Conference on Planning Now for Irrigation and Drainage, Lincoln, Nebraska, July 18-21, Proceedings, p. 694-699.

Deverel, S.J., 1988, Hydrologic processes affecting the distribution and mobility of salinity and selenium in shallow ground water, western San Joaquin Valley, California: American Society of Agronomy, 1988 California Plant and Soil Conference, Fresno, California, Proceedings, p. 1-3.

Deverel, S.J., 1989, Geostatistical and principal-component analyses of groundwater chemistry and soilsalinity data, San Joaquin Valley, California, in Stephen Ragone, ed., Regional Characterization of Water Quality: International Association of Hydrologic Sciences, Publication No. 182, p. 11-18.

Deverel, S.J., 1990, Distribution and mobility of trace constituẹts associated with irrigated agriculture in the Western United States (abs.): American Association for the Advancement of Science, Pacific Division, 71st, Davis, California, v. 9, part 1, p. 33.

Deverel, S.J., and Bell, R.B., 1988, Carbon mass transfer and isotopic evolution in shallow ground water, San Joaquin Valley, Califomia: Eos, Transactions of the American Geophysical Union, Abstracts, v. 69 , no. 44 , p. 1194.

Deverel, S.J., and Fio, J.L., 1989, Application of oxygen-18 and deuterium data to the understanding of selenium transport to agricultural drainage systems, San Joaquin Valley, California: Eos, Transactions of the American Geophysical Union, Abstracts, v. 70, no. 43, p. 1382.

Deverel, S.J., and Fio, J.L., 1990, Ground-water flow and solute movement to drain laterals, western San Joaquin Valley, California. I. Geochemical assessment: U.S. Geological Survey Open-File Report 90-136, 23 p.

Deverel, S.J., and Fujii, Roger, 1988, Processes affecting the distribution of selenium in shallow groundwater of agricultural areas, western San Joaquin Valley, California: Water Resources Research, v. 24 , no. 4, p. 516-524.

Deverel, S.J., and Fujii, Roger, 1990, Chemistry of trace elements in soils and ground water, chap. 4 in Tanji, K.K., ed., Agricultural salinity assessment and management: American Society of Civil Engineers Manuals and Reports on Engineering Practice No. 71, p. 64-90.

Deverel, S.J., and Gallanthine, S.K., 1989, Relation of salinity and selenium in shallow groundwater to hydrologic and geochemical processes, western San Joaquin Valley, California: Journal of Hydrology, v. 109, p. 125-149.

Deverel, S.J., and Millard, S.P., 1988, Distribution and mobility of selenium and other trace elements in shallow groundwater of the western San Joaquin Valley, California: Environmental Science and Technology, v. 22, no. 6, p. 697-702.

Dubrovsky, N.M., and Neil, J.M., 1988, Processes that control selenium distribution in ground water, western San Joaquin Valley, California: Eos, Transactions of the American Geophysical Union, Abstracts, v. 69 , no. 16, p. 364.

Dubrovsky, N.M., Neil, J.M., and Fujii, Roger, 1988, Possible redox control of selenium transport in a complex stratigraphic setting in the San Joaquin Valley, California: Eos, Transactions of the American Geophysical Union, Abstracts, v. 69, no. 44, p. 1181.

Fio, J.L., and Deverel, S.J., 1988, Ground-water flow to subsurface agricultural drains in the westem San Joaquin Valley, California: Eos, Transactions of the American Geophysical Union, Abstracts, v. 69 , no. 44 , p. 1188 .

Fio, J.L., and Deverel, S.J., 1989, Ground-water flow to subsurface agricultural drains in the western San Joaquin Valley, California, in Pederson, G.L., and Smith, M.M., compilers, U.S. Geological Survey Second National Symposium on Water Quality: Abstracts of the Technical Sessions, Orlando, Florida, November 17-19: U.S. Geological Survey Open-File Report 89-409, p. 25. 
Fio, J.L., and Deverel, S.J., 1990, Ground-water flow and solute movement to drain laterals, western San Joaquin Valley, California. II. Quantitative hydrologic assessment: U.S. Geological Survey Open-File Report 90-137, 15 p.

Fio, J.L., and Deverel, S.J., 1990, Interaction of shallow ground water and subsurface drains: Implications for selenium transport and distribution in the western San Joaquin Valley, California: Ground Water, v. 28 , no. 5 , p. $788-789$.

Fio, J.L., and Fujii, Roger, 1990, Selenium speciation methods and application to soil saturation extracts from San Joaquin Valley, California: Soil Science Society of America Journal, v. 54, no. 2, p. 363-369.

Fio, J.L., Fujii, Roger, and Deverel, S.J., 1990, Evaluation of selenium mobility in soil using sorption experiments and a numerical model, western San Joaquin Valley, California: U.S. Geological Survey Open-File Report 90-135, 13 p.

Fujii, Roger, 1988, Speciation of soluble and adsorbed selenium in soils, western San Joaquin Valley, California: Eos, Transactions of the American Geophysical Union, Abstracts, v. 69, no. 44, p. 1182.

Fujii, Roger, 1989, Speciation of soluble and adsorbed selenium in soils, western San Joaquin Valley, California, in Pederson, G.L., and Smith, M.M., compilers, U.S. Geological Survey Second National Symposium on Water Quality: Abstracts of the Technical Sessions, Orlando, Florida, November 17-19: U.S. Geological Survey Open-File Report 89-409, p. 28.

Fujii, Roger, and Burau, R.G., 1989, Estimation of adsorbed Se(IV) in soils, western San Joaquin Valley, California (abs.): American Society of Agronomy, Annual Meeting, Las Vegas, Nevada, December, p. 200.

Fujii, Roger, and Fio, J.L., 1988, Partitioning and speciation of soluble and adsorbed selenium in soils (abs.): American Society of Agronomy, 80th Annual Meeting, Anaheim, California, Agronomy Abstracts, November 27-December 2, p. 197-198.

Fujii, Roger, and Lipton, D.S., 1990, Mobility and solid-phase distribution of selenium in soils, western San Joaquin Valley, California (abs.): American Association for the Advancement of Science, Pacific Division, 71st, Davis, California, v. 9, part 1, p. 36.

Gilliom, R.J., 1989, Selenium in the San Joaquin Valley: Sources, distribution, and mobility: U.S. Geological Survey Yearbook, Fiscal Year 1988, p. 30-34.

Gilliom, R.J., and Clifton, D.G., 1990, Organochlorine pesticide residues in bed sediments of the San Joaquin River, California: Water Resources Bulletin, v. 26, no. 1, p. 11-24.

Gilliom, R.J., and Hill, B.R., 1989, Improvements in estimating trace-element loads using daily suspendedsediment data, San Joaquin River, California: Eos, Transactions of the American Geophysical Union, Abstracts, v. 70, no. 43, p. 1106.

Gilliom, R.J., and others, 1989, Preliminary assessment of sources, distribution, and mobility of selenium in the San Joaquin Valley, California: U.S. Geological Survey Water-Resources Investigations Report 88-4186, 129 p.

Gronberg, J.M., 1989, Data processors for use in ground-water modeling: American Society of Civil Engineers, Water Resources Planning and Management, 16th Annual Conference, Proceedings, 3 p.

Gronberg, J.M., Belitz, Kenneth, and Phillips, S.P., 1990, Distribution of wells in the central part of the western San Joaquin Valley, California: U.S. Geological Survey Water-Resources Investigations Report 89-4158, 51 p.

Heimes, F.J., Gronberg, J.M., and Carlson, J.R., 1988, Applications of a geographic information system to hydrologic siudies in the San Joaquin Valley, California: GIS Symposium, National Academy of Science, Denver, Colorado, September 25-30, 2 p.

Laudon, Julie, and Belitz, Kenneth, 1989, Texture and depositional history of near-surface alluvial deposits in the central part of the western San Joaquin Valley, California: Bulletin of the Association of Engineering Geologists, v. 28, no. 1, p. 73-88.

Millard, S.P., and Deverel, S.J., 1988, Nonparametric statistical methods for comparing two sites based on data with multiple nondetect limits: Water Resources Research, v. 24, no. 12, p. 2087-2098.

Neil, J.M., and Beard, Sherrill, 1988, Stratigraphy and mineralogy at the transition between oxidizing and reducing sediments in the San Joaquin Valley, California: Eos, Transactions of the American Geophysical Union, Abstracts, v. 69, no. 44, p. 1181. 
Neil, J.M., Lipton, D.S., and Doner, H.E., 1989, Mineralogical changes during sequential extraction procedure for determining the partitioning of selenium in soil of the western San Joaquin Valley, California: Clay Minerals Society, 26th Annual Meeting, Sacramento, California, September 25-28, p. 51.

Phillips, S.P., and Belitz, Kenneth, 1988, Calibration of a texture-based model of a ground-water flow system, western San Joaquin Valley, California: Eos, Transactions of the American Geophysical Union, Abstracts, v. 69, no. 44, p. 1188.

Phillips, S.P., and Belitz, Kenneth, 1990, Calibration of a texture-based model of a ground-water flow system, western San Joaquin Valley, California: U.S. Geological Survey Open-File Report 90-573, $30 \mathrm{p}$.

Shelton, L.R., 1989, Improved sampling methods for organic constituents, in Pederson, G.L., and Smith, M.M., compilers, U.S. Geological Survey Second National Symposium on Water Quality: Abstracts of the Technical Sessions, Orlando, Florida, November 17-19: U.S. Geological Survey Open-File Report 89-409, p. 89.

Shelton, L.R., and Miller, L.K., 1988, Water-quality data, San Joaquin Valley, California, March 1985 to March 1987: U.S. Geological Survey Open-File Report 88-479, 210 p.

Yates, M.L., Walker, W.J., and Burau, R.G., 1989, The San Joaquin Valley Drainage Program. A comparison of multiple-laboratory determinations of arsenic, boron, chromium, molybdenum, and selenium in reference materials and other environmental samples (abs.): Quality Assurance Symposium, 1989 Rocky Mountain Conference on Analytical Chemistry, Denver, Colorado, July 30-August 4, no. 321. 


\title{
INVESTIGATION OF LAND SUBSIDENCE, SACRAMENTO VALLEY; APPLICATION OF A NEW TECHNIQUE FOR INVESTIGATION OF LAND SUBSIDENCE
}

\author{
Number: CA459
}

\author{
Cooperating Agency: California Department of Water \\ Resources
}

Project Chief: Marti E. Ikehara

Period of Project: October 1985 to September 1991

Problem: Land subsidence of more than 4 feet since 1960 has been estimated in parts of the Sacramento Valley as a result of increased ground-water pumping. The effectiveness of many floodways, levees, and drains has been impaired by this subsidence. In the Sacramento Valley, many benchmarks used to measure subsidence have questionable elevations. In addition, the aquifer mechanics responsible for land subsidence in the Sacramento Valley have not been studied.

Objectives: Evaluate and apply a new surveying procedure called Global Positioning System (GPS), which provides a rapid and relatively inexpensive method of repeat leveling. Document existing land subsidence and describe the aquifer mechanics involved in subsidence. Establish a monitoring program to detect any continuing subsidence.

Approach: Initially, a pilot study will be made to evaluate the GPS survey capabilities. If the GPS is considered suitable, the methods will be used to survey a primary network of stable benchmarks and a secondary network in areas of known and possible subsidence. A field inventory of unused or abandoned wells that are suitable for extensometer, piezometer, and possibly strain meter installation will be made in areas of suspected subsidence. If suitable existing wells cannot be located, new wells will be drilled. These wells will be used to monitor the overall magnitude and rate of subsidence at each site.

\section{Progress:}

FY1988: In November 1987, a 2-inch extensometer well was constructed to a depth of 1,001 feet at a site 8 miles north of Woodland. Four nested piezometer wells, with screened intervals isolated by grout, were completed near the extensometer well. The screened intervals are at about 785, 585, 385, and 190 feet. A data logger and analog recorder were installed in June 1988 to record extensometer movement, water levels, temperature, and air pressure. Preliminary results indicated subsidence of about 0.1 foot until August, followed by a continuing rebound. Water-level changes were rapid and quite large--ranging from 30 feet in the deepest well to as much as 100 feet in the well completed in the most-used aquifer. Resurveying of the 11-mile line between Zamora and Knights Landing was completed in August 1988. Subsidence of 0.4 foot over the past 2 years occurred in the middle of the line, with lesser amounts indicated at each end. A progress report on the performance and applicability of Global Positioning System survey procedures to define extent, magnitude, and rate of land subsidence in the Sacramento Valley was written and reviewed.

FY1989: A GPS survey was done from July 12 to September 14, 1989. The network consisted of 68 bench marks; 32 were previously surveyed by GPS methods. A minimum of 83 baselines comprise the network which covers an area bounded by Chico and Orland in the north and Clements and Fairfield in the south. A loop from Jersey Island in the delta west to San Francisco was surveyed using bench marks adjacent to tidal gages. Eleven offset bench marks were constructed and surveyed. The Woodland 
Transect, including the extensometer installation, was resurveyed. More than 10 miles of a closed loop were surveyed conventionally in conjunction with the GPS network. The extensometer installation recorded water levels at 30-minute intervals for four zones of ground water, soil compaction, atmospheric pressure, and instrument temperature. Subsidence was recorded from about April through July 1989, corresponding to the seasonal water-level declines. A total of 4 inches of compaction occurred, compared to only 2 inches of rebound during the previous wet season, August through March. Applied stress increase apparently is exceeding the preconsolidation stress, resulting in virgin (nonrecoverable) compaction.

FY1990: Three test holes were drilled in the Sacramento Valley to obtain undisturbed cores of finegrained material for laboratory analyses. The cores will be tested at the Survey research lab in Golden, Colorado, for consolidation parameters, size distribution, and permeability. Five cores were obtained from a site near Laguna Creek south of Sacramento, an area experiencing rapid urbanization and increased ground-water pumping. The test hole was converted to a deep (618 feet) and a shallow (258 feet) piezometer installation. Near Ordbend, one core was recovered before unmanageable cobbles forced drilling to be terminated prematurely. Four cores were obtained from a test hole at the water-level and compaction site near Woodland. A fifth piezometer was installed at this site and is screened in the shallowest zone. Data from this site show that compaction of 4.7 inches more than last years 4 inches occurred during the irrigation season. Water levels declined rapidly at the start of pumping and were lower than last year and equivalent to the lows of the 1977 drought year. Resurveying of the line between Zamora and Knights Landing corroborated continuing subsidence. Several miles of surveying was accomplished to provide ties between benchmarks of interest to California Department of Water Resources and those used by the U.S. Geological Survey. Data from several surveys between 1985 and 1989 were stored in a spreadsheet format, which facilitates calculations for spatial and temporal elevation differences.

Plans for Next Year: Results of the Global Positioning System surveys will be analyzed and presented in a paper to be given at the Fourth International Symposium on Land Subsidence. Laboratory results of the sediment cores will be analyzed with regard to subsidence potential for the areas where the cores were collected. Data from the instruments at the compaction and water-level monitoring site near Woodland will be analyzed with respect to aquifer mechanics.

Reports:

Blodgett, J.C., Ikehara, M.E., and Williams, G.E., 1988, Land subsidence monitoring in the Sacramento Valley using global positioning system surveys (abs.); American Society of Civil Engineers Specialty Conference GPS-88, Nashville, Tennessee, May 11-14, 1 p.

Blodgett, J.C., Ikehara, M.E., and Williams, G.E., 1990, Monitoring land subsidence in Sacramento Valley, California, using GPS: American Society of Civil Engineers Journal of Surveying Engineering, v. 116 , no. 2, p. 112-130. 


\section{IRRIGATION DRAINAGE FIELD-SCREENING STUDY OF KLAMATH BASIN REFUGE COMPLEX}

Number: CA460

Cooperating Agency: U.S. Department of the Interior

Project Chief: Stephen K. Sorenson

Period of Project: October 1987 to September 1990

Problem: Drainage from irrigated agricultural operations have caused a contamination problem at or near several Federally operated wildlife refuges. Agricultural return flows often contain contaminants (such as pesticides) and trace elements (such as selenium), which have known impacts on biota. The operation of many wildlife refuges requires the use of some agricultural return flows because this is often the only source of water for the refuge. Continued use of these waters may jeopardize the use of the refuges for wildlife.

Objectives: Determine whether irrigation drain water

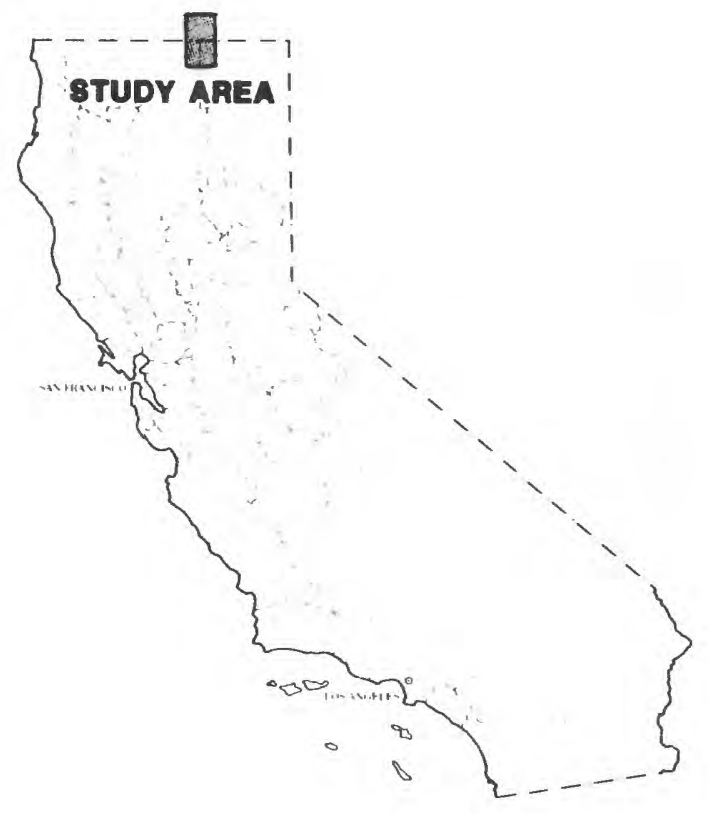
has caused, or has the potential to cause harmful effects on human health, fish and wildlife, and other beneficial water uses in the study area.

Approach: The Klamath and Tule Lake Wildlife Refuges will be sampled once during 1988 at a time when contamination is most likely to be found. Wildfowl, invertebrates, and plant material will be sampled during the May through June nesting period. Water, bottom material, and biological samples to be analyzed for pesticides and trace elements will be collected in August 1988 during the maximum irrigation period. During 1989, data will be analyzed and a water-resources investigations report will be written.

\section{Progress:}

FY1988: All water, bottom material, and biological samples listed in the proposal document were collected and sent to the U.S. Geological Survey and U.S. Fish and Wildlife Service laboratories for analysis. Preliminary work was started on a water-resources investigations report that will summarize the findings of this study.

FY1989: All chemical analysis of samples sent to the U.S. Geological Survey and the U.S. Fish and Wildlife Service laboratories were received by June. A large part of the summary report was completed.

FY1990: The water-resources investigations report was completed and approved for publication.

Plans for Next Year: None. Project completed.

\section{Reports:}

Sorenson, S.K., and Schwarzbach, S.E., 1991, Reconnaissance investigation of water quality, bottom sediment, and biota associated with irrigation drainage in the Klamath Basin, California and Oregon: U.S. Geological Survey Water-Resources Investigations Report 90-4203, 64 p. 


\title{
GEOHYDROLOGIC INVESTIGATION OF THE SACRAMENTO VALLEY AREA
}

\author{
Number: CA461
}

Cooperating Agency: California Department of Water Resources

Project Chief: James W. Borchers

Period of Project: October 1985 to September 1990

Problem: Ground-water-level declines of more than 60 feet, land subsidence of more than 2 feet, and the potential for upward migration of deeper saline water have prompted the California Department of Water Resources and the U.S. Geological Survey to cooperatively investigate the geohydrology of the Sacramento Valley and Redding Basin. Previous studies have revealed difficulties in characterization of aquifer properties, quantification of stream-aquifer interaction, and estimation of ground-water pumpage.

Objectives: Describe and analyze the ground-water-flow system in the Sacramento Valley and Redding Basin to aid water-resource managers in the decision-making process. Quantify the hydrologic and geologic characteristics of the ground-water-flow system, stresses on that system, and the relation between streamflow and the system. Create a Geographic Information System (GIS) controlled data base that will be easily accessible for future project work in the Sacramento Valley and Redding Basin.

Approach: A GIS-controlled data base will be created to manage data compiled from driller's and electric logs, geologic maps, soil surveys, power company pumpage records and existing topographic, geologic, and hydrologic data. Stream-aquifer interactions will be studied by combining a water-budget and a water-chemistry approach. Methods currently used to estimate agricultural ground-water pumpage by comparing method-generated pumpage figures with measured pump discharge at field locations will be improved. The GIS data base will be used to develop a ground-water-flow model that will indicate weaknesses in the data base. The data base will be expanded and improved as needed.

\section{Progress:}

FY1988: Data on the alluvial texture of sediments filling the Sacramento Valley were compiled from driller's logs, electric logs, and gamma logs for 223 wells near Mather Air Force Base (AFB), Sacramento, 353 wells between Putah and Cache Creeks on the west side of the Sacramento Valley, and 2,382 wells at Davis and Stockton--potential sites for the Super-Conducting Super Collider. An investigation of the hydrogeologic framework of aquifers near Mather AFB was begun. All wells on Mather AFB and within 2 miles of the Mather AFB boundary were inventoried. Maps of the distribution of potentiometric head were prepared for three depth zones. The distribution of coarse-grained alluvium was analyzed by the preparation of maps indicating percentage of coarse-grained secdiment in each of the three zones, and in 45 separate 10-foot thick layers from 300 feet below mean sea level to land surface.

FY1989: Analysis of sedimentary textural data in Yolo County indicated that drillers' logs underestimate the amount of coarse-grained sediments by almost 10,683 of the total 151,748 feet of alluvial deposits penetrated by the 396 wells. Drillers' logs overestimate the amount of fine-grained material by 3,000 feet and contain about 2.5 times the amount of missing or ambiguous data as electric logs. Therefore, electric logs were used to map the sedimentary texture distribution. Analysis of water levels and sedimentary texture distribution near Mather AFB showed that alluvial deposits are unsaturated and coarsest near land 
surface. Between 30 and 200 feet below mean sea level, alluvial deposits become continuously finer grained, are saturated, and in places are contaminated with solvents and fuels. Deeper than 200 feet below mean sea level, alluvial deposits become coarser grained, produce most ground water used at the airbase, and are not contaminated. A report describing the distribution of coarse-grained sediments and water levels near Mather AFB was completed and submitted for review. A series of GIS coverages, including alluvial texture, geology, canals, streams, roads, and political boundaries were created for Yolo County.

FY1990: A report describing the distribution or sedimentary texture and water levels in the Mather Air Force Base area was revised in response to reviewers comments. Digital map (ARC/INFO) coverages of the Yolo County sedimentary texture study were documented and archived. Specific capacity data were collected for 24 percent of the wells in the Sacramento Valley for which electric logs are available to characterize the distribution of sedimentary texture. Comparison of the two data bases will allow general relations between sedimentary texture and aquifer characteristics to be developed. A cooperative arrangement with eight Sacramento Valley water agencies and cities allowed five university students to work as Survey volunteers while in the employ of the local agencies. These students collected and viewed 300 videotapes made using down-well television cameras. Some wells were damaged by compressive stress caused by land subsidence. The amount of vertical compression in the well casing was measured from the videotapes. Well construction and well location data were compiled from the tapes and drillers' logs on file with Califormia Department of Water Resources. An ARC/INFO data base was created to geographically study the distribution of wells damaged by land subsidence in the Sacramento Valley.

Plans for Next Year: Project was suspended as a result of budget cuts experienced by the cooperator.

Reports: None. 


\section{EFFECTS OF URBAN STORMWATER RUNOFF ON THE SAN JOAQUIN RIVER NEAR FRESNO}

Number: CA465

Cooperating Agency: Fresno Metropolitan Flood
Control District

Project Chief: Joel R. Guay

Period of Project: October 1986 to September 1989

Problem: Although the Fresno Metropolitan Flood Control District (FMFCD) routes most urban stormwater runoff into retention/recharge basins, 5 to 10 percent of stormwater is discharged directly into the San Joaquin River from some agricultural and low- to medium-density residential areas. Runoff from these areas could affect agricultural irrigation, fishery and wildlife habitat, and various recreational activities near the San JoaquinSacramento River Delta. The final report of the 1981-84 Fresno National Urban Runoff Project by FMFCD recommended the effects of urban runoff into the San Joaquin River be evaluated.

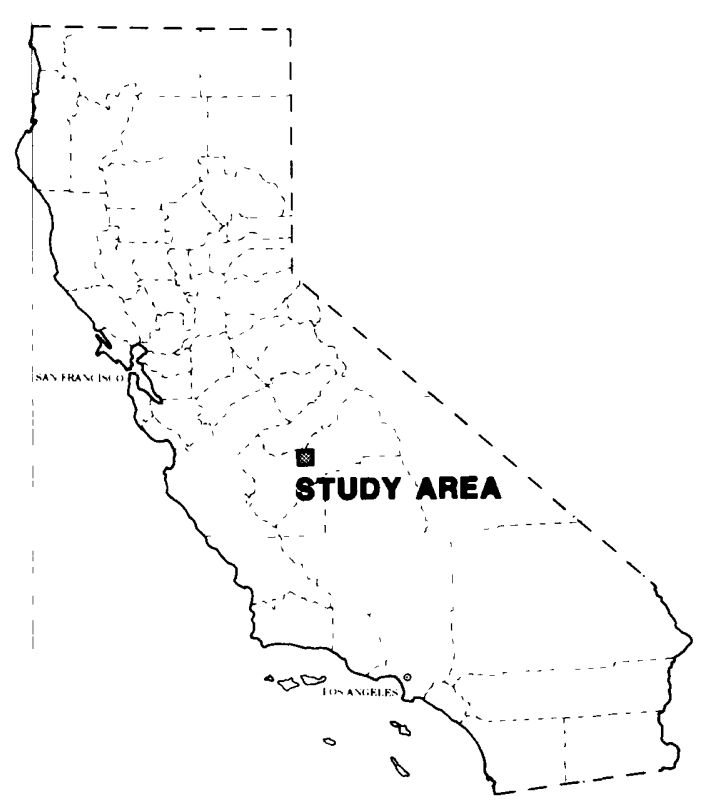

Objectives: Determine the effects of urban stormwater runoff on the water quality of the San Joaquin River near three urban stormwater outfalls in Fresno, California.

Approach: A rainfall-runoff model, a runoff-quality model, $\mid$ a one-dimensional riverflow model, and a branched Lagrangian transport model will be used to simulate a critical case of quality of storm-runoff and river loading for a 24-hour period. The 24-hour period represents a typical storm period for the Fresno area. Simulated 1-hour peak concentrations will be compared with the U.S. Environmental Protection Agency's (EPA) 1-hour freshwater aquatic-life criteria in order to infer which constituents would require a more detailed analysis.

\section{Progress:}

FY1988: Whole-water samples were collected at the upstream and downstream sites on the San Joaquin River on November 17, 1987, and February 17, April 19, June 29, and September 20, 1988. Bottommaterial samples were collected at the upstream and downstream sites on June 28 and September 20, 1988. The laboratory results showed consistently low whole-water and bottom-material constituent concentrations. Specific conductances ranged from 48 to 68 microsiemens per centimeter, and $\mathrm{pH}$ ranged from 6.6 to 7.2. Whole-water and bottom-material concentrations of pesticides were equal to or less than detection levels. Whole-water concentrations of metals also were equal to or less than the detection levels, except iron, which ranged from 100 to 200 micrograms per liter. All concentrations of bottom-material metals were less than 100 micrograms per gram, except aluminum (2,600 to 3,400 micrograms per gram) and iron (3,800 to 4,000 micrograms per gram). Hourly rainfall data from the National Oceanographic and Atmospheric Administration and the California Irrigation Management Information System for 1948-88 were reformatted into the Survey data-management system ANNIE. The Survey rainfall-runoff model (DR3M-II) was used with historical rainfall data to simulate long-term runoff of catchments DF, DG, and CO-1 into the San Joaquin River.

FY1989: Analytical results of whole-water samples collected in the San Joaquin River on September 29 and November 17, 1987, and February 17, April 19, June 29, and September 20, 1988, and bottommaterial samples collected on September 29, 1987, and June 28 and September 20, 1988, were published 
in the U.S. Geological Survey's annual data report. Samples of whole water (12) and bottom material (6) were collected during the study. Seven samples for total recoverable aluminum exceeded the EPA's aquatic life criteria. Chromium exceeded EPA criteria three times, copper twice, and lead once. The runoff-quality model was calibrated for total recoverable aluminum, arsenic, chromium, copper, iron, lead, mercury, nickel, and zinc.

FY1990: Calibrated one-dimensional flow and Lagrangian transport models were used with previously calibrated rainfall-runoff and runoff-quality models to simulate the flows and constituent mixing in the San Joaquin River near Fresno, Califormia. The results of the study were based on comparing the simulated 1-hour peak concentrations in the river with EPA 1-hour freshwater aquatic-life criteria. Constituents with simulated river concentrations greater than 10 times the respective EPA criteria were considered likely to exceed the criteria; however, no constituents were included in this group. Constituents with simulated river concentrations less than 1/10 the respective EPA criteria (mercury, nickel, and arsenic) were considered not likely to exceed the EPA criteria. The modeling approach was not considered sufficiently sensitive to determine the likelihood of the group between 10 times and $1 / 10$ the criteria (lead, aluminum, copper, zinc, and chromium) exceeding the EPA 1-hour criteria. The modeling study did, however, show that catchment-runoff controls could reduce the river load for these constituents by about one-fifth to three-fourths. The results of the study will be published in the proceedings of the American Water Resources Association symposia on "Transferring Models to Users" and "Urban Hydrology," which were held in Denver, Colorado, November 4-8, 1990.

Plans for Next Year: None. Project completed.

\section{Reports:}

Guay, Joel, R., 1990, Simulation of urban runoff and river water quality in the San Joaquin River near Fresno, California: American Water Resources Association, Symposium on Urban Hydrology, Denver, Colorado, November 1990, Proceedings, 5 p. 


\section{EVALUATION OF GROUND-WATER CONTAMINATION FROM NONPOINT SOURCES USING SOLUTE-TRANSPORT TECHNIQUES}

Number: CA466

Cooperating Agency: Santa Ynez River Water Conservation District

Project Chief: Daniel J. Bright

Period of Project: October 1986 to September 1990

Problem: Several studies have documented the deterioration of ground-water quality in the Lompoc subarea of the Santa Ynez River basin. These studies indicate that recharge of irrigation water probably is the principal cause of the observed deterioration. Ground water in the Lompoc subarea, especially in the Lompoc plain, is only marginally acceptable for most uses. Dissolved-solids concentrations currently exceed 2,000 milligrams per liter in several parts of the subarea. If the ground-water quality continues to deteriorate, the ground water will be unusable for almost all uses without some treatment.

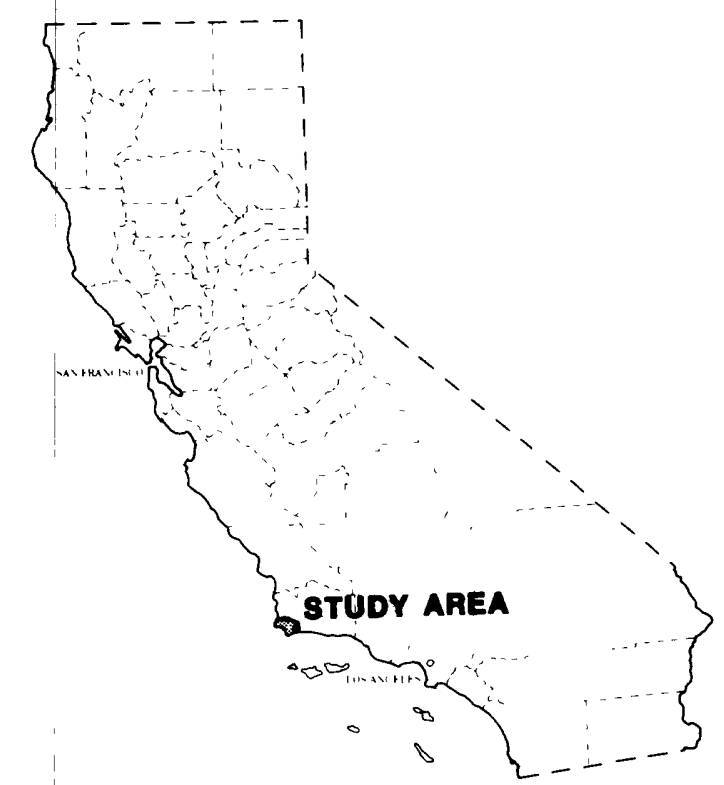

Objectives: Define the geohydrologic framework of the Lompoc subarea of the Santa Ynez River basin. Define quantitatively, where possible, the effects of irrigation on the quality of ground water. Evaluate ground-water flow and solute transport using numerical simulation.

Approach: Existing hydrologic data will be used to define the geohydrologic and geochemical framework of the study area. Observation wells and suction-cup lysimeters will be installed on four study plots that are typical of agricultural and geohydrologic conditions in the areas. Water levels will be monitored monthly, and wells will be sampled bimonthly. A three-dimensional finite-difference ground-water-flow model will be developed to simulate flow through unconsolidated deposits that fill the basin in the subarea. The vertical movement of solutes will be simulated using a two-dimensional finite-element solute-transport model.

\section{Progress:}

FY1988: Ground-water samples and water-level measurements were collected quarterly from 25 observation wells and two suction-cup lysimeters installed by the Survey in March and October 1987. Water samples were analyzed for major ions and nutrients. Additional data collection consisted of deuterium and oxygen-18 isotope analyses (30 samples), weekly water-level measurements from wells adjacent to the Santa Ynez River (17 sites), continuous water-level recorder measurements (2 sites), seepage-loss measurements, and aquifer tests ( 3 sites). A computer data base was compiled from 1,434 wells currently stored in the U.S. Geological Survey ground-water site inventory and water-quality data files. Computer programs were written to access the data and create data files that will be used to generate graphics, such as water-level hydrographs, water-quality chemographs, and various contour maps of individual aquifers in the Lompoc plain. A three-dimensional ground-water-flow model for the Lompoc plain and upland areas was constructed. Initial attempts to calibrate the model for steady-state and transient-state conditions were made. Ground-water conditions in 1941 are considered to be representative of steady-state flow. Ground-water conditions from 1942 to 1988 will be used to calibrate the model to time-dependent conditions. 
FY1989: Technical review of the phase 1 report, which describes the geohydrology and water-quality conditions in the Lompoc area for 1987-88, was completed. Calibration of the ground-water-flow and solute-transport models continued. Flow of ground water in the main water-producing zone and in adjoining units in the upland and Lompoc terrace is simulated with a four-layer, pseudo-three dimensional finite-difference model, MODFLOW. Flow of ground water and solute transport in the main-water preducing zone are simulated with a finite-element model, SATRA-FEM. Although SATRA-FEM is a two-dimensional model, it permits the simulation of vertical leakage from overlying and underlying aquifers. Hydraulic heads above and below the main water-producing zone and fluxes to and from the adjoining upland and terrace areas are calculated with MODULAR and then used as input to the SATRAFEM model. Several programs were developed to accurately translate the input and output data of the MODULAR model to input data for the SATRA-FEM model. Using the MODULAR and SATRA-FEM in tandem further constrains the models by allowing simulated dissolved-solids concentrations to be used in the calibration of the MODULAR model.

The annotated outline for the phase 2 report was reviewed. This report will evaluate ground-water flow in the Lompoc area and solute transport in the Lompoc plain using numerical simulation. The development and calibration of the flow and solute-transport models will be described. Effects of selected management alternatives on water levels and water quality will be evaluated.

FY1990: The report on phase 1 of this study, evaluating geohydrology and water-quality conditions of the Lompoc area, was prepared for approval. In phase 2 of the study, ground-water-flow and solutetransport models were developed and calibrated to simulate a 48-year period of historical record. The models were developed as a means of evaluating the conceptualized flow and transport systems. Preliminary model results indicate that pumping of ground water for irrigation and municipal use has induced movement of water of high dissolved-solids concentration into the main water-producing zone in various parts of the Lompoc plain.

Plans for Next Year: Sensitivity analyses for the ground-water-flow and solute-transport models will be completed. Selected management alternatives will be simulated using both models, and the effects of the alternatives on water levels and water quality will be evaluated. Results from both models will be presented in a phase 2 report on numerical simulation of ground-water flow and solute transport.

Reports: None. 


\section{OPTIMUM MANAGEMENT IN A BASIN WITH CHANGING WATER-SUPPLY AND WATER-QUALITY PROBLEMS}

Number: CA467

Cooperating Agency: San Bernardino Valley Municipal
Water District

Project Chief: Wesley R. Danskin

Period of Project: October 1987 to September 1991

Problem: Historically, water purveyors have applied various techniques to solve their water-supply and waterquality problems. Although most water purveyors rely on some form of conjunctive use of ground and surface waters, seldom is there optimum management of the entire water system. Improved management of complex hydrologic systems should be possible by developing and applying hydraulic- and economic-optimization techniques. But, to date, the actual use of optimization techniques to solve real-world water-supply and water-quality problems has been limited.

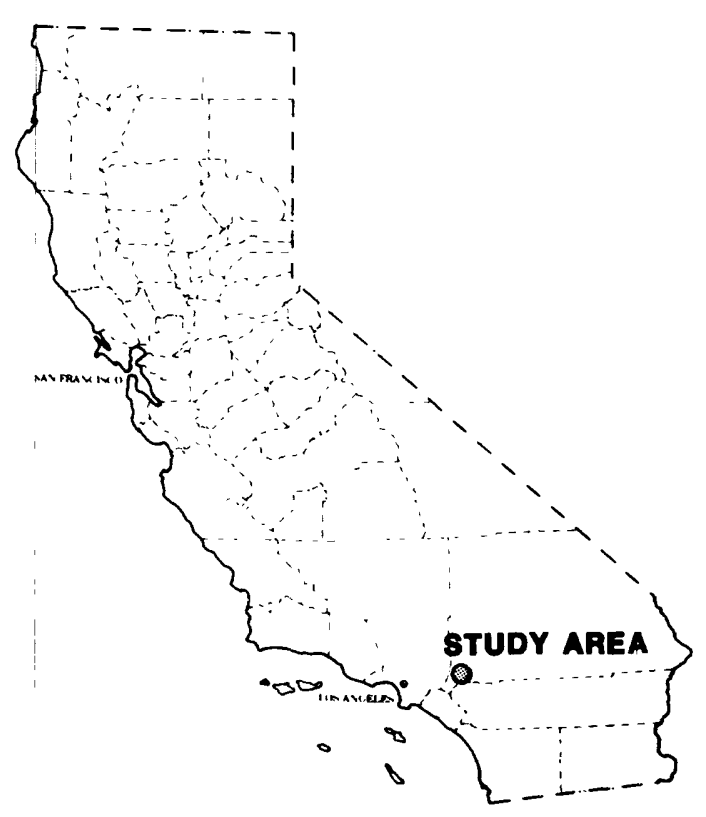

Objectives: Develop and apply optimization techniques to demonstrate their usefulness in a real-world setting for conjunctive management of ground-water pumpage, ground-water levels, quality of ground water, and artificial recharge of surface water. Research will focus on developing new methodologies to incorporate system and parameter uncertainty in the optimization model.

Approach: Key aspects of the ground-water system will be verified to ensure accurate simulation with the existing ground-water-flow model. A surface-water distribution model will be designed and constructed. Critical water-quality problems and potential management options will be identified. A hydraulic/economic-optimization model will be developed that combines the surface- and ground-water models with the water-quality issues. New methods of water management will be evaluated.

\section{Progress:}

FY1988: The existing ground-water-flow model of the Bunker Hill basin was resurrected and critiqued. Because of limitations of the model in simulating fluxes and changes in storage, a survey of alternative flow and solute model codes was made. Data from the existing flow model are being calibrated in a new ground-water-flow model using the U.S. Geological Survey modular model finite-difference code. Recent pumpage and surface-water data were collected and were used to extend the original calibration period. A surface-water data base program, ANNIE, was used to analyze and prepare surface-water data for use in the ground-water-flow and management models. The critical water-management issues, which become objective functions and constraints in the management model, were compiled. The general formulation of the optimization problem was identified (nonlinear objective function with linear and nonlinear constraints). The selection of appropriate optimization codes was made--in particular, MINOS (Modular In-core Nonlinear Optimization System) with a recently developed mixed-integer option, and GAMS (General Algebraic Modeling System) with its ease of manipulating nonlinear constraints, such as surfacewater/ground-water interactions. A forum comprising the various water agencies in the San Bernardino area was used to present preliminary findings from the study and to receive feedback from the water agencies. Experience with other water-management studies indicates that this interaction will play a key role in achieving positive results from the study. 
FY1989: The period of simulation of the ground-water-flow model was extended from 1945-74 to 1945-86. A Geographical Information System (GIS) was used to transfer detailed results from the model to other ongoing studies in the basin. Initial analysis of the surface-water distribution system was completed, and the major components were linked to the ground-water model using a surface-water routing model. The management model, which uses mathematical optimization techniques, includes surface-water, ground-water, and water-quality aspects of the basin. Artificial recharge and ground-water pumpage are included in the management model using results from the ground-water-flow model. Water-quality problems in the basin were reviewed, and two areas with high concentrations of trichloroethylene (TCE) and perchloroethylene (PCE) were included in the management model. The cost of importing water and pumping local ground water was identified as the key economic issues. The management model is being used to analyze alternate methods of basin operation, such as tilting the regional water table using a combination of artificial recharge and pumpage, while at the same time not exacerbating the TCE/PCE problems. The effects of uncertainty in aquifer parameters are being incorporated in the management model.

FY1990: Virtually all surface-water inflow and outflow for the Bunker Hill basin was quantified for 1945-89. Analysis of the surface-water system was expanded to include all major streams, canals, pipes, and recharge ponds. These features were incorporated in a much more detailed surface-water model. The linked surface- and ground-water models simulate the movement of water through the basin and provide input to the management model. The water-management model now includes surface-water, ground-water, water-quality, and economic aspects. Additional water-management questions that are addressed using the models include: (1) identifying the mininum combination of pumpage and artificial recharge needed to contain a TCE plume that is moving through the basin while also assuring that the downtown area, which is susceptible to liquefaction, is dewatered and ground-water levels on the alluvial fans are maintained at present levels; (2) identifying the preferred location and number of extraction wells needed to contain the TCE plume. The effect of uncertainty of surface-water inflow has been quantified and is being used to interpret results from the management model. Installation of multilevel piezometers was completed in order to verify results of the models and to guide management decisions.

Plans for Next Year: The management model will be used to evaluate more complex problems involving multiple areas of TCE contamination, proposed areas of artificial recharge, and possible alteration of surface-water channels. The effect of parameter uncertainty on the management model will be extended to include ground-water quality. Two reports will be written--one summarizing results of the study and one documenting the simulation and management models.

Reports: None. 
WATER RESOURCES OF THE CAMBRIA-SAN SIMEON AREA, SAN LUIS OBISPO COUNTY

Number: CA468

Cooperating Agency: San Luis Obispo County
Engineering Department

Project Chief: Eugene B. Yates

Period of Project: October 1987 to September 1990

Problem: Almost all municipal and agricultural water use in the Cambria-San Simeon area relies on ground water from shallow alluvial ground-water basins underlying San Simeon and Santa Rosa Creeks. Because of anticipated population growth and the small size of the ground-water basins, there is concern whether the ground-water resource is sufficient to meet future demands. Large seasonal increases in salinity in wells near the coast and high ambient concentrations of iron and manganese in the Santa Rosa Creek basin pose additional water-supply problems.

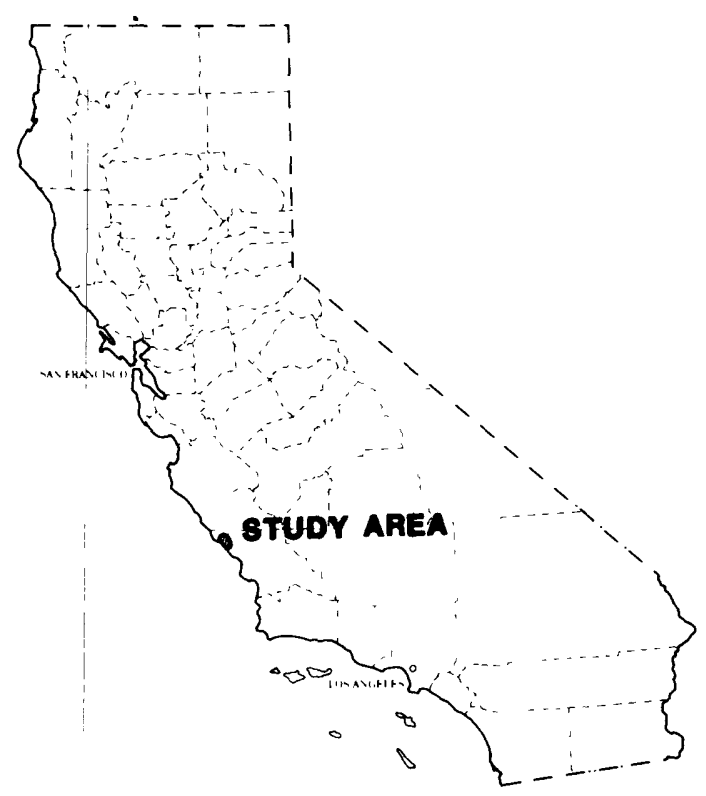

Objectives: Define the surface- and ground-water hydrology of the basins. Define existing ground-water quality in the alluvial aquifers and determine those factors affecting the quality. Investigate the likelihood and consequences of droughts. Evaluate the effectiveness of water-resources management alternatives.

Approach: Water budgets and flow patterns will be investigated using digital ground-water-flow models. Because seepage from the creeks is the primary source of ground-water recharge, a thorough statistical analysis of streamflow will be done. Spatial and temporal trends in water quality will be delineated using new and existing data.

\section{Progress:}

FY1988: Literature review and data collection were emphasized during the first year of the study. Two continuous-recording stream gages were installed, and occasional discharge measurements were made at 12 sites. Water levels at 24 wells were measured monthly by the Survey, and an additional 20 wells were measured monthly by the Cambria Community Services District. Rainfall was measured at five locations, and a Penman type climate station began recording potential evapotranspiration in July 1988 . Well efficiency was measured at 17 irrigation wells to calculate agricultural pumpage from monthly measurements of electricity use. Cropping patterns were monitored quarterly along San Simeon and Santa Rosa Creeks. Observation wells were drilled at five locations in August 1988. Two of the wells were screened at two separate depth intervals. Data from previous aquifer tests and water-quality measurements were used to design additional tests for this study.

FY1989: Hydrologic monitoring ended in March 1989, at which time 15 complete months of data had been obtained. Data included measurements of rainfall, temperature, streamflow, cropping patterns, water quality, electricity use by irrigation wells, and ground-water levels. Climate measurements and cropping patterns were analyzed using a soil-moisture-accounting algorithm to estimate crop water use. Field measurements of reference evapotranspiration $\left(\mathrm{ET}_{0}\right)$ using the Penman method indicated that $\mathrm{ET}_{0}$ reported by the California Department of Water Resources' CIMIS stations could be averaged to estimate ET in $_{0}$ the Cambria area. The algorithm was used to calculate daily soil-moisture budgets for 97 fields and indicated that agricultural water use was about 890 acre-feet per year in the Santa Rosa Creek basin and 450 acre-feet per year in the San Simeon Creek basin. Surface-water quality was sampled twice at six locations. Ground-water quality was sampled at 13 wells and springs before and after winter recharge of 
the ground-water basins. Samples were analyzed for major ions, nitrates, and selected minor ions. Ground water along both creeks was noticeably more saline within 1 mile of the ocean. Deep observation wells near the coast in both basins yielded water that failed to meet drinking-water standards because of high salinity. Ground- and surface-water samples showed a small influx of poor-quality water into the Santa Rosa Creek basin from the Perry Creek basin. Hydraulic properties of the aquifer were estimated from aquifer tests and from water-level recoveries during a streamflow event in December 1988. Geologic and aquifer-test data also indicate that transmissivity is greater along the valleys than across them.

FY1990: Two-dimensional finite-element ground-water-flow models were developed for the Santa Rosa Creek and San Simeon Creek ground-water basins. The models were calibrated to match measured water levels and streamflow during April 1988 through March 1989. The calibration process showed significant differences between the two basins. Basin-fill deposits in the San Simeon Creek basin are more permeable and homogeneous than in the Santa Rosa Creek basin. Ground water does not emerge as seepage into the creek except along a short reach near the coast. In the Santa Rosa Creek basin, sediments are less permeable and less homogeneous. Subsurface flow restrictions in three locations force ground water into the creek, creating year-round baseflow in some reaches. Model simulations were used to investigate the effects of pumpage and drought. Municipal pumpage affects water levels throughout the San Simeon Creek basin but only locally in the Santa Rosa Creek basin. Municipal pumpage in the Santa Rosa Creek basin could be increased by 100 acre-feet per year without causing seawater intrusion, but there would be a slight risk of subsidence in dry years. Statistical analysis of historical streamflow and rainfall record indicate that a winter with little or no streamflow--and consequently little or no ground-water recharge--is likely to occur about once every 35 years. Simulations of these conditions indicated that about one-half the wells in each basin would go dry and significant amounts of seawater intrusion would occur.

Plans for Next Year: The final report will be reviewed and submitted for approval.

Reports: None. 


\section{RAINFALL AND RUNOFF IN THE ANTELOPE VALLEY DRAINAGE AREA}

Number: CA469

Cooperating Agency: Los Angeles County Department of Public Works

Project Chief: James C. Blodgett

Period of Project: October 1987 to September 1992

Problem: Effects of storm runoff in drainage basins being urbanized in Antelope Valley, California, are a major concern. Increases in effective impervious areas in new developments cause increases in storm runoff volumes and peak magnitude. Reliable and regional methods to estimate storm runoff is needed for land-use planning, establishing land development criteria, and designing drainage facilities. Because numerous rainfallrunoff models are available, local development regulatory agencies are confronted with the problem of selecting the correct model for their region.

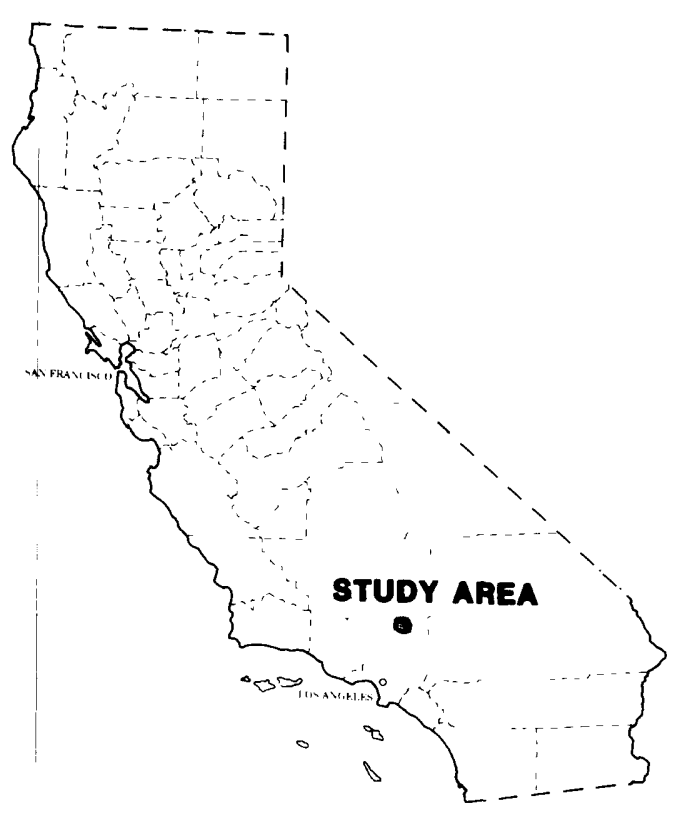

Objectives: Instrument and measure rainfall and runoff in nine drainage basins in Antelope Valley. Test and compare various rainfall-runoff models to simulate measured runoff. Derive runoff frequencies for long-term simulation and select a rainfall-runoff model appropriate for estimating design storm characteristics in ungaged drainage basins in Antelope Valley.

Approach: Nine basins will be selected for collection of continuous flow and precipitation data. These basins will represent urbanized and nonurbanized conditions. Using data plus suitable historical data, the various rainfall-runoff models will be calibrated and results evaluated. Basins will be selected to provide four types of hydrologic data: flood magnitude and frequency and precipitation-runoff model calibration; flow duration and frequency; and flow attenuation in a downstream direction. Aerial photography and infiltration measurements will be obtained to evaluate characteristics of the basins and flow for model application.

\section{Progress:}

FY1988: A reconnaissance survey indicated nine sites suitable for gaging stations. Eight gaging stations were constructed and water-stage recording equipment was installed. These sites were selected to provide data for natural and urban conditions. Preliminary calculations of basin characteristics were made and precipitation data were compiled. These data will be used to estimate frequency of flow and to provide precipitation frequency, flow duration, and attenuation data.

FY1989: All gaging and precipitation stations were installed and are operated. Streamflow and precipitation data for the 1989 water year were processed; however, no significant storm occurred during the year. A special software program was prepared to signal data collection on the basis of storms above a threshold value to reduce data-collection processing time and computer storage requirements. Efforts were made to assemble and analyze existing rainfall-runoff data for a historical gaging station. Precipitation data were collected from nearby national climatic stations. An evaluation of the rainfall-runoff data will be used to identify significant basin and precipitation factions in the study area.

FY1990: Streamflow and precipitation data for the 1990 water year was processed; however, no significant storms occurred during the past year. Current efforts are to assemble and analyze existing rainfall data for all long-term precipitation stations in order to provide rainfall frequency and areal distribution data 
in Antelope Valley. Precipitation data collection continued at each gaging station. Infiltration measurements using a DC infiltrometer were obtained for all nine study basins. The DR3M computer model is being set up to evaluate the importance of various rainfall and runoff parameters so that special emphasis on collecting or assembling these data can be made. The PRIMS model also will be applied to determine its applicability to the study area. An evaluation of the rainfall-runoff data will be used to identify significant basin and precipitation factors in the study area and adapt these data to regional basis for Antelope Valley.

Plans for Next Year: Rainfall-runoff data will be collected on a continuing basis and processed using a format suitable for modeling. Newly collected data will be applied to both rainfall-runoff models. The models will be calibrated and compared with other selected models. The rainfall-runoff model will be extended to include historical data for selected precipitation stations to better define the frequency of rainfall and corresponding runoff.

\section{Reports:}

Blodgett, J.C., Nasseri, Iraj, and Elliott, A.L., 1990, Urban hydrology in the desert, Antelope Valley, California: American Society of Civil Engineers, Hydraulics/Hydrology of Arid Lands, San Diego, Proceedings, p. 96-101. 


\section{DETAILED STUDY AND ASSESSMENT OF IRRIGATION DRAINAGE IN THE SALTON SEA AREA, IMPERIAL VALLEY}

Number: CA470

Cooperating Agency: U.S. Department of the Interior

Project Chief: James G. Setmire

Period of Project: October 1987 to September 1990

Problem: A reconnaissance investigation of irrigation drainage in the Salton Sea area has indicated that selenium and, to a lesser extent, boron originating from irrigation drainage within the Imperial Valley are a potential threat to the health of fish and wildlife of the Salton Sea National Wildlife Refuge. A health advisory has been issued limiting the consumption of fish caught in the Salton Sea to 4 ounces per 2 weeks. To date, there have been no studies to document the effects of selenium and boron on reproduction, body condition, survivability, and other mortality factors on any wildlife species in the

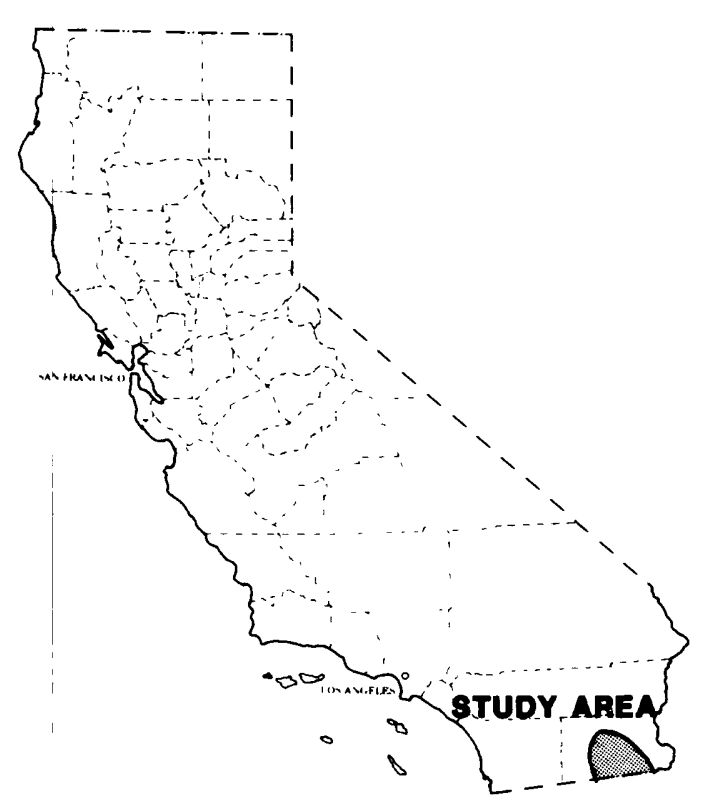
area.

Objectives: (1) Determine the geographical extent and severity of existing and potential irrigation-induced water-quality problems. Provide scientific knowledge needed for development of reasonable alternatives to mitigate or resolve identified problems.

Approach: A flow chart was developed for the movement of selenium through the agricultural system of the Imperial Valley. This flow chart begins with selenium present at low levels in irrigation water and ends with the detection of selenium in fish and wildlife in the Salton Sea area. From this hypothesized pathway, nine tasks were developed to elucidate the mechanisms and processes controlling the movement and bioaccumulation of selenium. These tasks involve subsurface-drainwater sampling to determine temporal and spatial patterns in selenium concentration, selenium loading to the Salton Sea, uptake by resident and migratory birds, and nesting and habitat studies of selected species. These tasks will be carried out by a team composed of U.S. Geological Survey and U.S. Fish and Wildlife Service personnel.

\section{Progress:}

FY1988: The work plan for continuing investigation of irrigation drainage in the Salton Sea area was reviewed during a workshop from November 30 to December 2, 1987, at the Survey office in Sacramento. A revised plan was forwarded to Survey headquarters in February 1988. Task 1 of the work plan, the study of the correlation between selenium concentrations in tile-drain effluents and the leaching history of agricultural fields, began May 16. A total of 130 water samples were collected from tile drains previously sampled in 1986 by the California Regional Water Quality Control Board. Analyses include stable isotopes, tritium, selenium, boron, arsenic, dissolved solids, and major cations and anions. Task 2, the study of selenium concentrations in the Alamo River delta, began the week of August 22. Bottom material and algal mats were sampled for determination of selenium concentration, and water-column samples were collected for analysis of selenium, boron, stable isotopes, dissolved solids, and major cation and anion concentrations. Soil samples from 15 agricultural fields in the Imperial Valley were sampled as part of a cooperative agreement with the California Regional Water Quality Control Board. A total of 270 soil samples were collected for analyses of total selenium concentration and selenium concentration in the saturation extract. 
FY1989: Data were collected to determine temporal variations in the chemistry of drain water from selected fields in the Imperial Valley. Water samples were collected monthly from sumps draining 15 agricultural fields where soil cores previously were obtained. Monthly water samples also were collected from the New and Alamo Rivers at the international boundary and at their outlets to the Salton Sea. Two drainage ditches were sampled. The river and drainage-ditch sampling, along with the drain-water sampling, focused primarily on selenium, boron, dissolved solids, and nutrients--with periodic analysis for major ions. Stable isotopes of hydrogen and oxygen were collected to determine the evaporative history of the drain water and the degree of mixing between irrigation water from the fields and ground water. As part of a cooperative program with the California Regional Water Quality Control Board, multiple-depth wells and lysimeters were installed at three sites in the Imperial Valley to determine the chemistry of water beneath the fields.

FY1990: Data were analyzed and interpreted and report writing was completed. Preliminary data analysis indicates that selenium, detected at low concentrations in Colorado River water, concentrates by evaporation in the upper soil horizons in agricultural fields of the Imperial Valley. This concentrated water is intercepted beneath the fields by a network of subsurface drains and then discharged through sumps to ditches. Most of these ditches empty to the New or Alamo Rivers, which terminate at the Salton Sea. Regression of hydrogen- and oxygen-isotope ratios $\left(100 \times r^{2}=96\right)$ shows that Colorado River water is the single source of subsurface drainwater in the Imperial Valley. The slope of 5.36 for the regression line also shows that evaporation is controlling the observed range in dissolved-solids concentration. Ratios of selenium to chloride indicate that selenium moves conservatively through the agricultural system. Similar ratios were found in the Colorado River, subsurface drainwater (average of values), and in the Alamo River at the outlet of the Salton Sea. Calculation using a discharge-weighted selenium concentration in subsurface drainwater and the concentration and load of selenium in the Alamo River at the outlet to the Salton Sea shows that about 64 percent of the water at the outlet site has a quality equivalent to that of the Colorado River, and thus the Alamo River dilutes subsurface drainflow from the Imperial Valley.

Plans for Next Year: The final report, which covers study objectives for both the U.S. Geological Survey and the U.S. Fish and Wildlife Service, will be completed. Coordination of study results with ongoing work to be done by the U.S. Bureau of Reclamation will be maintained.

Reports: None. 


\section{CHANGES IN RUNOFF IN PERRIS VALLEY, RIVERSIDE COUNTY}

Number: CA472

Cooperating Agency: Riverside County Flood Control and Water Conservation District

Project Chief: Joel R. Guay

Period of Project: October 1988 to September 1993

Problem: Increased urbanization in Perris Valley since 1970 has caused appreciable changes in the runoff characteristics. Additional impervious area has resulted in increased runoff volumes and peak discharges. Few studies have documented what effect urbanization has on runoff characteristics. Because rainfall/runoff data for Perris Valley prior to urbanization is available, a current study could determine how urbanization has affected runoff characteristics in Perris Valley.

Objectives: Compare current runoff characteristics in

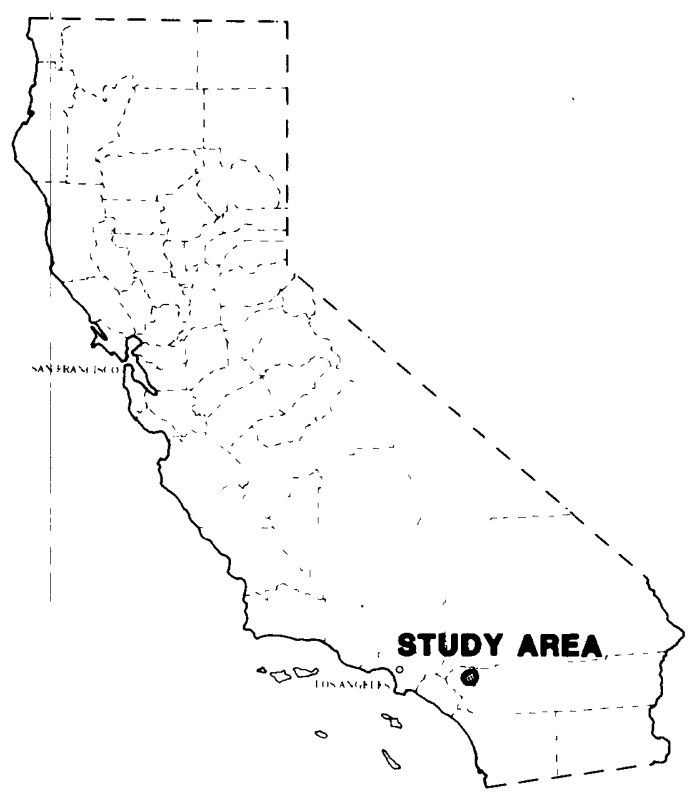
urbanized Perris Valley with runoff characteristics prior to urbanization.

Approach: Rainfall-runoff data collected from 1989 to 1992 will be used to calibrate and verify a rainfall-runoff model. A rainfall-runoff model also will be calibrated and verified using the 1970-75 rainfall-runoff data. The results of the two models will be compared to determine what effect urbanization has on runoff characteristics.

\section{Progress:}

FY1989: Sites $9,15,17$, and 21 from a previous study of Perris Valley will be retained for this study. A new site at Lake Perris was used to determine the soil moisture and infiltration parameters used in the rainfall-runoff models. Site 9 was refurbished and will be completed as soon as a permit for an orifice line is secured from the city of Moreno Valley. Sites 15 and 17 were refurbished and are ready for installation of gaging equipment. New gage houses were constructed at site 21 and the new Lake Perris site. Weirs were constructed at sites 15 and 21 to sensitize the discharge rating. All gaging equipment was ordered and installed by the end of the fiscal year.

FY1990: Data were collected from 12 storms during water year 1990 to develop a posturbanization rainfall-runoff model of Perris Valley. Because of a severe drought year, only about 5 inches of rain fell on the basin. Stage-discharge ratings were developed at five locations using recorded stage and measured discharge data, or standard culvert ratings. The preurbanization rainfall-runoff model was schematized into overland-flow, channel, and pipe segments using 1974 aerial photographs and storm-drain plans of the basin. Data from a previous study of Perris Valley (1970-75) will be used to calibrate the preurbanization model.

Plans for Next Year: Another year of rainfall-runoff data for the post-urbanization model will be collected. The preurbanization model will be completed. Work will begin on the preliminary development of the posturbanization model.

Reports: None. 


\section{WATER RESOURCES AND GEOHYDROLOGY OF THE CITY AND COUNTY OF SAN FRANCISCO}

Number: CA473

Cooperating Agency: San Francisco Water Department

Project Chief: Eugene B. Yates

Period of Project: October 1988 to September 1991

Problem: The San Francisco Water Department currently meets public supply demands by importing water from the Tuolumne River and Hetch Hetchy Reservoir in the Sierra Nevada. Expanded development of local water resources, primarily for nonpotable use, could reduce the dependency on imported water. However, better definition of the local water resources and geohydrology will be needed for future development.

Objectives: Define the water resources and geohydrology of the city and county of San Francisco.

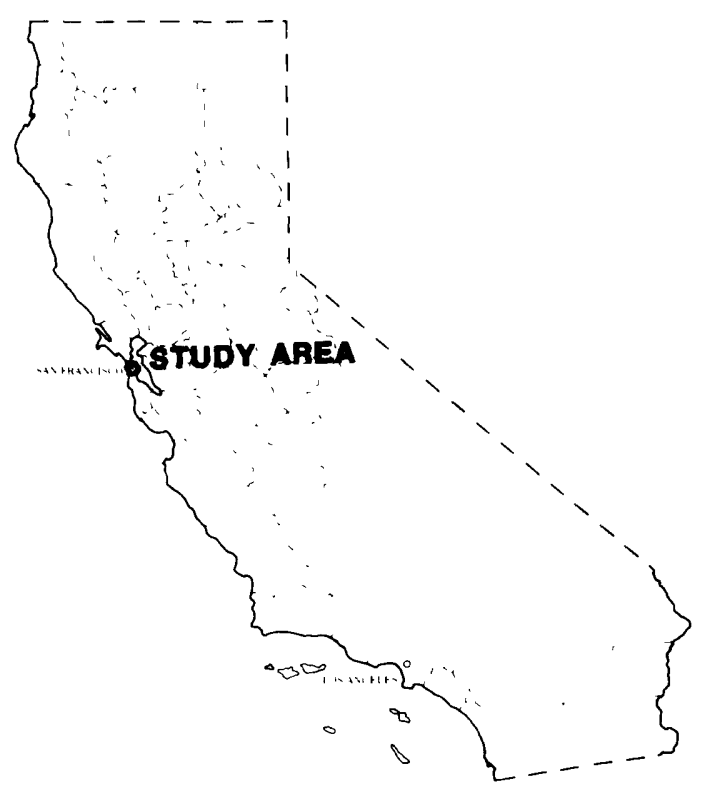
Specifically, assess water use and ground-water conditions in Golden Gate Park, Fleishhacker Zoo, and Lake Merced. Develop a work plan and cost estimate for the final phase of the study.

Approach: Literature and geohydrologic data will be reviewed and analyzed. Pumped wells will be metered by the San Francisco Water Department. The Survey will supervise tests to determine well and aquifer hydraulic characteristics. Pumping rates and water levels will be monitored. Ground-water-level recorders will be installed at suitable sites. Major-ion and isotope analyses will be done by Survey laboratories. Additional analyses to determine potable and nonpotable water use will be done by the San Francisco Water District laboratory. Geohydrologic and chemical information will help classify water types, determine surface and ground-water relations, and develop hydrologic budgets.

\section{Progress:}

FY1989: A report was prepared for review. Five shallow observation wells (between 50 and 80 feet deep) were installed during June 1989. During September 1989, deep boreholes (224 to 1,500 feet) were drilled at three locations. Casing was installed to depths of 280,600, and 1,500 feet in the Fort Funston borehole; 50, 145, and 400 feet in the Golden Gate Park borehole; and 35 and 140 feet in the San Francisco airport borehole. Data collected from these boreholes will be used to calibrate gravity data, determine depth to bedrock, and define lithologic characteristics. Data collected from the monitoring wells will show hydraulic and water-quality variations and may determine the potential for seawater intrusion. Data collection includes water-quality sampling, water-level measurements, and compilation of hydrologic data (rainfall, municipal water use, and sewer flow). Water samples were collected at 21 sites in December 1988 and May 1989 to determine major-ion and stable-isotopic composition. Water levels were measured monthly at 28 sites and seasonally at 19 sites. Rainfall data for San Francisco were compiled for 1987-89. Municipal and suburban water-use figures were compiled for the same period. Additionally, sewer-flow data were compiled for the 1986 and 1987 water years.

FY1990: Major accomplishments during the past year included interpretation of gravity data, completion of water-quality sampling, analysis of sources of nitrate in ground water, development of water budgets in San Francisco, and completion of many input packages of a ground-water flow model. A bedrock contour map was prepared using hundreds of gravity measurements collected during 1988-89. These data were calibrated using available borehole data. In general, the new bedrock map resembles previous 
versions, but differs in detail. Analyses of water-quality samples were completed. Samples for major ions, tritium, nitrogen isotopes, and stable isotopes were collected in May and December 1989, and April 1990. The distribution of values for nitrogen-isotope ratios indicates that sewers and fertilizers supply about equal amounts of the nitrogen load to ground water. Sources of nitrate to ground water in the Lake Merced area were evaluated using additional water-quality information and a refined water budget. Sewers and fertilizers apparently contribute equivalent amounts of nitrate to ground water. Water budgets for the San Francisco sewer system have been developed for wet and dry weather conditions. During rainstorms, the amount of runoff reaching the sewers is unusually low. Conversely during dry periods, an unexplained gain in flow is observed. A large part of the input to the ground-water-flow model was completed. The model grid, land-use zones, and topography were converted to ARC/INFO data base coverages for this purpose. Also, the basin, block-centered flow, river, and well packages were compiled.

Plans for Next Year: The above analyses will be refined and incorporated into the ground-water-flow model. The model will be used to describe response of the system to natural and manmade events and to address water-management issues.

\section{Reports:}

Yates, E.B., Hamlin, S.N., and McCann, L.H., 1990, Geohydrology, water quality, and water budgets of Golden Gate Park and the Lake Merced area in the westem part of San Francisco, Califomia: U.S. Geological Survey Water-Resources Investigations Report 90-4080, 45 p. 


\section{GROUND-WATER HYDRAULICS IN WOLF VALLEY, RIVERSIDE COUNTY}

Number: CA474

Cooperating Agency: Pechanga Indian Reservation

Project Chief: Charles A. Kaehler

Period of Project: October 1988 to September 1991

Problem: Population and water use are skyrocketing in the upper Santa Margarita River basin. Rancho California Water District (RCWD), which supplies water to most of the area, will be relying more heavily on local ground-water resources to meet future water needs. In Wolf Valley, adjacent to the area served by RCWD, there is concern that RCWD pumping in the valley will cause ground-water levels to decline and will deplete groundwater storage beneath the Pechanga Indian Reservation. Much of the water for the reservation is pumped from a shallow alluvial aquifer, while most of the larger wells in the valley pump water from a deep aquifer.

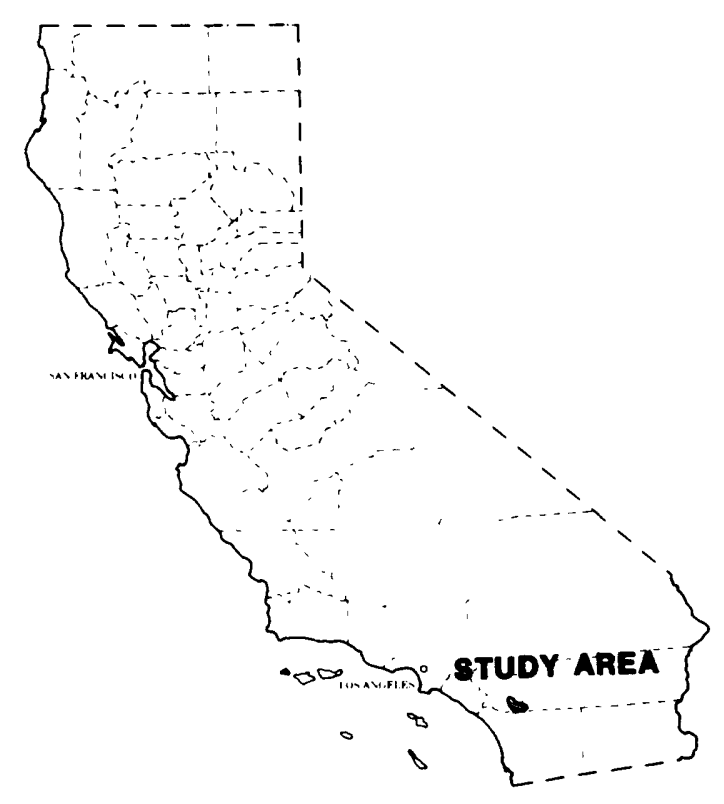

Objectives: Collect hydrologic data, conduct aquifer tests, and construct a digital model to gain a greater knowledge of ground-water hydraulics in the multiple-aquifer system of Wolf Valley. The effect of pumping on ground-water levels and storage beneath the Pechanga Indian Reservation will be emphasized.

Approach: All available data on well construction, aquifer tests, subsurface geology, historical water levels, and pumpage for Wolf Valley will be collected. The existing water-level monitoring program (10 wells) will continue. All available wells will be measured in the autumn and spring of each year. Four or five test holes will be drilled to supplement existing geologic data, and the holes will be logged. Two nests of piezometers will be installed near a large production well. A long-term aquifer test (30-60 days) will measure the hydraulic properties of the shallow and deep zones as well as the confining unit. A three-dimensional ground-water-flow model will be developed.

\section{Progress:}

FY1989: Monitoring of water levels, collection of available geologic and hydrologic information, and canvassing of additional wells continued. The data will be used to select locations for observation wells, to design of aquifer tests, and to develop a flow model. Meetings with the cooperator resulted in revision of project plans. U.S. Geological Survey will expand the number and depth of planned piezometers and test holes, and the cooperator will drill a large-capacity test well.

FY1990: A deep pilot hole was drilled to collect hydrogeologic data and to facilitate planning of a highcapacity test well. In addition, 10 piezometers were constructed for use as observation wells during a long-term pumping test and to monitor water levels and water quality. Eight of the piezometers were completed at various depths (80-790 feet) on either side of the Wolf Valley fault on the Kelsey Tract of the Pechanga Indian Reservation. Drill cuttings and geophysical logs from the piezometers confirmed the existence of a fine-grained zone in this part of the valley. Depth to bedrock was 960 feet at the pilot hole. Water levels in the piezometers confirmed the existence of the fault and showed that it acts as a partial barrier to ground-water flow. Water-quality data indicated that ground water in the shallow and deep aquifer zones differs with respect to major dissolved ions and in concentration of nutrients. Monitoring of ground-water levels and water quality continued, and data were compiled. A talk was presented to the cooperator summarizing current knowledge of the hydrologic system. Water-quality samples were 
collected and analyzed and the results were transmitted to the cooperator. Sieving and particle-size analysis of lithologic samples from the nearby pilot hole was done to aid in the design of the test well. The well was constructed in August 1990, and a step-drawdown test was done.

Plans for Next Year: The remainder of the study primarily will consist of a long-term aquifer test using the test well and piezometers (all located on the Kelsey Tract of the reservation); analysis of data; construction of analytical solutions (distance/drawdown graphs), using knowledge of the aquifer system and data from the aquifer test to evaluate possible future impacts on the Kelsey Tract of large-scale pumping in Wolf Valley; and writing of the report. A flow model will not be a part of this phase of the study.

Reports: None. 


\section{EFFECTS OF NONPOINT SOURCE RUNOFF FROM ALAMEDA COUNTY ON SOUTH SAN FRANCISCO BAY}

Number: CA475

Cooperating Agency: Alameda County

Project Chiefs: Stephen K. Sorenson and Peter D. Dileanis

Period of Project: October 1988 to September 1991

Problem: Population growth in the San Francisco Bay area has caused concern over water quality in all areas of the bay. Because nonpoint-source runoff from urbanized areas adjacent to San Francisco Bay may be contributing to water-quality degradation of the bay waters, the California Regional Water Quality Control Board--San Francisco Bay Region has directed Alameda County to document contaminant loading from nonpoint sources to the bay, originating from drainage basins in the county. This project will evaluate the effects of these contaminants on the bay in conjunction with Alameda County's study of contaminant discharges from nonpoint sources.

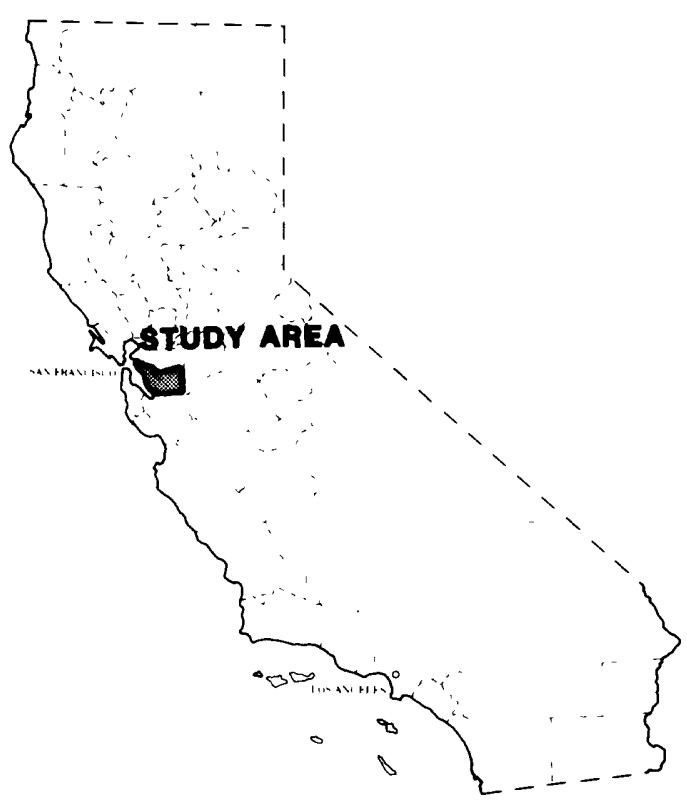

Objectives: Define the spatial and temporal characteristics of freshwater plumes and associated suspended sediment resulting from storm flows in the three largest Alameda County tributaries to south San Francisco Bay. Determine the rate and area of dispersion of contaminants that are transported to the south bay by urban runoff from Alameda County.

Approach:: Fresh water from storms discharged from San Lorenzo Creek will be monitored as it enters the bay and disperses. This will be done with automatic conductivity sensors in shallow waters and by boat-mounted sensors in deeper water. Chemical and biological constituents, such as trace metals, organic compounds, and viruses characteristic of nonpoint-source runoff will be sampled at the stream outflow and at various points in the bay to determine the dispersion of these contaminants in the bay waters and sediments.

\section{Progress:}

FY1989: Much of the planned data collection for 1989 was not completed until after the 1989 storm season because of equipment problems. Several tasks necessary to successfully carry out the 1990 storm sampling were completed. The Loran navigation instrument, which will be used for precise location of sampling points, was calibrated and programmed. Several successful deployments and recoveries of automatic data collectors were completed. Much experience has been gained in methods of handling the bacteriophage tracer. Organisms were grown in the laboratory and should be ready to use as tracers during the latter part of the 1990 storm season. Collection of bottom sediments for trace-element analysis was completed in September 1989 at 22 locations along the Alameda County coastline.

FY1990: Data collection began, however, the lack of substantial runoff during this fourth year of drought has limited the scope of the data-collection program. Bottom-sediment samples were collected from 22 sites located off the Alameda County coastline before and after the winter storm season. Chemical analysis indicated uniformly high concentrations of mercury and nickel in the sediments. Sites in San Leandro Bay also had relatively high concentrations of lead and zinc, both common contaminants from urban environments. Water samples for analysis of specific conductance, turbidity, and suspendedsediment concentrations were collected during or immediately after seven storms from January through 
April 1990. Samples were collected from a boat offshore of San Lorenzo Creek at fixed, uniformly spaced sampling stations. Six to eight continuously monitoring temperature-conductivity meters were deployed at selected sites to collect data when sampling from the boat was not possible. Preliminary data analysis indicated that freshwater plumes are rapidly mixed when they enter the bay resulting in a gradual and fairly widespread gradient of decreasing conductivities from deeper water toward the shore. Extensive laboratory work preliminary to the use of a bacteriophage as a freshwater tracer was completed. The methodology is sufficiently developed to allow field trials during the next storm season.

Plans for Next Year: Bed sediments will be sampled again before and after next winters storms. The bacteriophage tracer will be incorporated into the sampling plan and water-column sampling will be expanded to include San Leandro Bay and offshore of Alameda Creek.

Reports: None. 


\title{
DEVELOPMENT OF SACRAMENTO RIVER BED-SCOUR RELATION AT THE SR-32 BRIDGE AT HAMILTON CITY
}

Number: CA476

\section{Cooperating Agency: California Department of Transportation}

\author{
Project Chief: James C. Blodgett
}

Period of Project: October 1988 to September 1992

Problem: Exposure or undermining of the bridge pier and abutment foundations from the erosive action of flowing water at the State Route 32 bridge at Hamilton City, California, can result in bridge failure or the need for expensive repairs. Bridge-scour data are difficult to obtain, partly because major scour usually occurs during flood conditions. As a result, actual measurements of scour that can be used to define significant bridge and channel characteristics in causing scour, and comparison of scour data with laboratory derived relations, are needed.

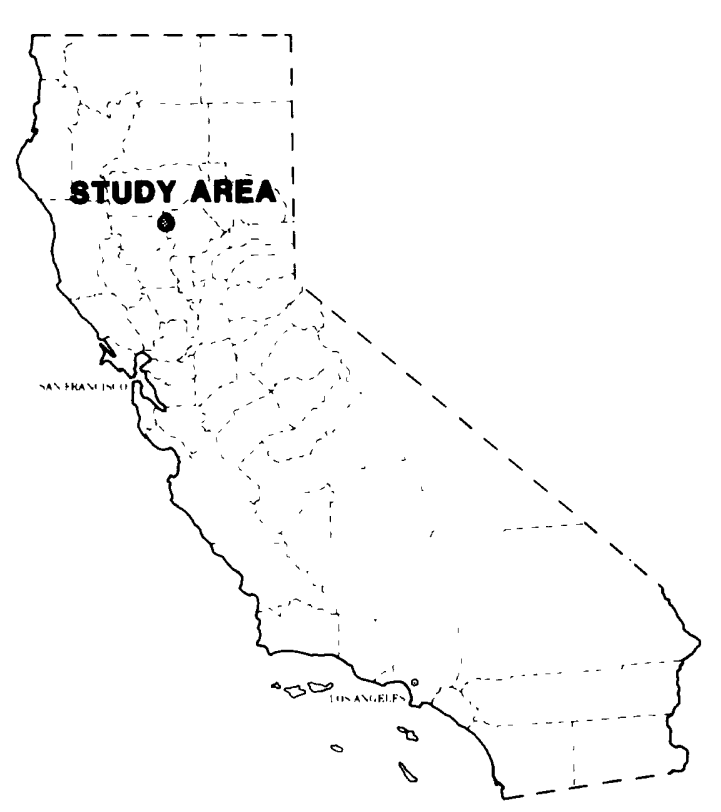

Objectives: Determine those hydraulic and bridge geometric factors that are important in the cause and extent of channel-bed scour. Develop equations to predict depth and lateral extent of scour at the old and new bridges and compare with scour equations for other sites. Determine the rate of channel stabilization associated with constriction and local scour at the new bridge.

Approach: Channel-survey data obtained near the old bridge site will be used to relate bridge geometry and to indicate typical channel conditions. Scour and hydraulic data at the new bridge will be collected about four times per year and stored: once before the flood season, twice during the flood season, and once after the flood season. Geophysical soundings will be obtained annually to provide information on the maximum depth of scour below the surveyed channel bed. Data will be analyzed and separated into the components of channel bed, constriction, and local scour. Constriction and local scour will be related to bridge geometry.

\section{Progress:}

FY1989: Channel and bridge-scour data were collected in October 1988 and April and July 1989. Geophysical data were obtained in October 1988. Analysis of the data indicated that three types of scour occur at the study site: (1) channel scour, which is a natural phenomena on alluvial-bed streams; (2) constriction scour caused by the bridge and levees; and (3) local scour caused by bridge piers. The geophysical method best suited to measure the gravel and cobble bed-material site is deep penetrating radar.

FY1990: Channel and bridge-scour data were collected in October 1989 and April 1990. A paper describing the types of scour and various methods for establishing a response plan was given at the symposium on bridge scour in October 1989. New survey and sounding equipment that provides data in the $\mathrm{x}, \mathrm{y}$, and $\mathrm{z}$ planes was tested and used to provide scour data at the SR-32 site. This equipment was demonstrated by California District personnel in Connecticut in May 1990. Flooding did not occur during the water year, so data needed for a complete analysis of scour conditions at the site are unavailable. 
Plans for Next Year: Collection of scour depth and channel-geometry data will continue with emphasis on collecting scour data during several moderately high-flow events. If suitable floods occur, scour data will be collected around the bridge piers. An evaluation of previously collected scour data, especially that collected at the old bridge, will be completed and a final report prepared if sufficient flooding occurs so that an adequate range of data can be obtained.

\section{Reports:}

Blodgett, J.C., 1989, Monitoring channel scour at the SR-32 bridge across the Sacramento River at Hamilton City, California (abs.): Bridge Scour Symposium, McLean, Virginia, October 17-19, 1989,2 p. 


\title{
GROUND-WATER RESOURCE INVESTIGATIONS, EDWARDS AIR FORCE BASE
}

\author{
Number: CA477
}

\section{Cooperating Agency: Edwards Air Force Base}

Project Chief: Clark J. Londquist

Period of Project: January 1988 to September 1990

Problem: Declining water levels, an apparent decrease in water quality, and an antiquated water-distribution system have resulted in a water shortage at Edwards Air Force Base. In addition, there has been widespread landsurface subsidence in the southwest part of the base, and an extensive system of cracks, fissures, and potholes has developed on Rogers Lake (dry). This has generated concern about the condition of runways on the lakebed.

Objectives: Define the boundaries and areal extent of the ground-water system. Quantify the distribution of

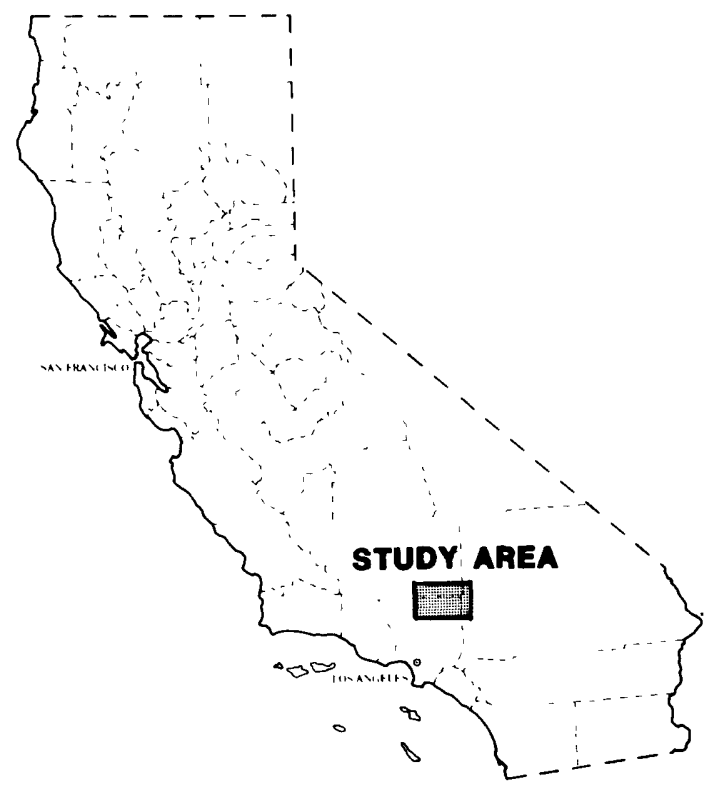
hydrologic properties. Determine ground-water recharge and discharge. Define the aquifer water types. Develop a long-term ground-water monitoring program. Identify sites for development of future well fields. Determine the influence of surface water flood flows on playa surface morphology. Determine the areal extent and amounts of land-surface subsidence. Determine the extent and cause(s) of fissures, cracks, and potholes on the lakebed. Evaluate the effect of these fissures and cracks on the geomorphology of existing stream networks entering and on the lakebed. Determine measures that may be used to control or prevent lakebed cracking and possibly hasten lakebed repair by natural means.

Approach: Gravity, seismic refraction, and direct current resistivity methods will be used to identify the geologic structure and boundary conditions of the ground-water basin. Exploratory drilling will be done. Water-quality samples will be collected. Piezometers will be installed at various levels to establish a multilevel monitoring network. Aquifer tests will be done. Well-field hydraulics will be modeled. Waterlevel and water-quality data for wells on and adjacent to the airbase will be inventoried and collected. Evidence of land subsidence and surface deformation will be obtained by spirit-level and Global Positioning System (GPS) surveys, aerial photography of the lakebed, and monumentation of selected fissures. Extensometers will be installed to measure the amount and rate of subsidence at selected locations.

\section{Progress:}

FY1989: Historical ground-water data were compiled. Assistance was given to Edwards Air Force Base in locating a site for a new production well. Surveys to establish a vertical control network for the air base and vicinity were started. A major part of the network was established using GPS surveys, which were based on three bench marks located on bedrock. Results of GPS surveys and supplemental thirdorder-leveling surveys indicated that land subsidence since 1961 ranges from 0.1 to 3.2 feet around Rogers Lake bed, but with the greatest subsidence in the southwest part of the base. Aerial photography was obtained to compare present lakebed fissuring with historic conditions.

FY1990: Exploratory test drilling was done at four sites on the base, and 11 piezometers were installed for monitoring water levels and water quality. About 1,040 gravity measurements were added to the existing gravity data base, and more than 140 vertical electric soundings, using direct current resistivity methods, were made to help define the base of the aquifer system, to characterize the sedimentary basin fill, to identify potential areas for further ground-water exploration, and to isolate zones which may be contributing to land subsidence. Eleven seismic refraction spreads were used to determine the depth to 
water and bedrock in a well field being considered for expansion. Borehole geophysical logs, including suites of geoelectric, natural gamma, sonic, and caliper logs, have been obtained at seven drill sites. The logs provided detailed information on the subsurface stratigraphy, aided in the placement of piezometers to measure hydraulic head fluctuations in specific layers, and were used to determine the placement of an extensometer well drilled near the south track well field. The extensometer, which measures the amount and rates of subsidence, became fully operational in May 1990. The results of the test drilling and various geophysical methods were used in selecting sites for several new production wells. Surveys to establish an up-to-date vertical control network for the base and vicinity were continued. Supplemental spirit-level surveys were made to provide detailed areal coverage of the study area. New surveys indicate that more than 4 feet of land subsidence occurred near Lancaster. Progress reports presenting the results of the work to date were in preparation.

Plans for Next Year: Several exploratory test holes will be drilled and equipped with multiple piezometers. Surface and borehole geophysical information will be collected to help define the groundwater system. Existing wells on and adjacent to the airbase will be inventoried. Water-level and waterquality monitoring networks will be established over the study area. Vertical control network at selected locations will continue using GPS surveys and spirit-level surveys to areas affected by land subsidence to provide a reference for future measurements defining amounts and rates of land subsidence. New highresolution photographs will be analyzed for geometric and geomorphic characteristics of drainage channels and fissures on the lakebed. Selected fissures will be monumented to begin an evaluation of surface deformation on the lakebed and to identify locations of potential fissures. Additional GPS surveys will be analyzed using test wells drilled on the lakebed at selected locations. These surveys will provide a regional network that can be tied to detailed lakebed surveys and also improve the relation between ground-water levels and channel formation and erosion on the lakebed.

Reports: None. 


\section{EVALUATION OF SUBSIDENCE RATES AND PROCESSES IN SURFICIAL PEAT, SACRAMENTO-SAN JOAQUIN DELTA}

Number: CA479

Cooperating Agency: California Department of Water
Resources

Project Chief: Steven J. Deverel

Period of Project: October 1989 to September 1993

Problem: The land in the Sacramento-San Joaquin Delta has been subsiding because of oxidation of organic soils caused by loss of carbon at a rate of 1 to 3 inches per year since the drainage of the islands and tracts began in the early part of this century. Oxidation of these soils is the result of microbial consumption of organic carbon. Continued subsidence threatens the integrity of the levee system and will increase the amount of energy required to maintain a low water table for crop production. Knowledge of the processes contributing to subsidence of these soils will provide a basis for water- and landmanagement strategies.

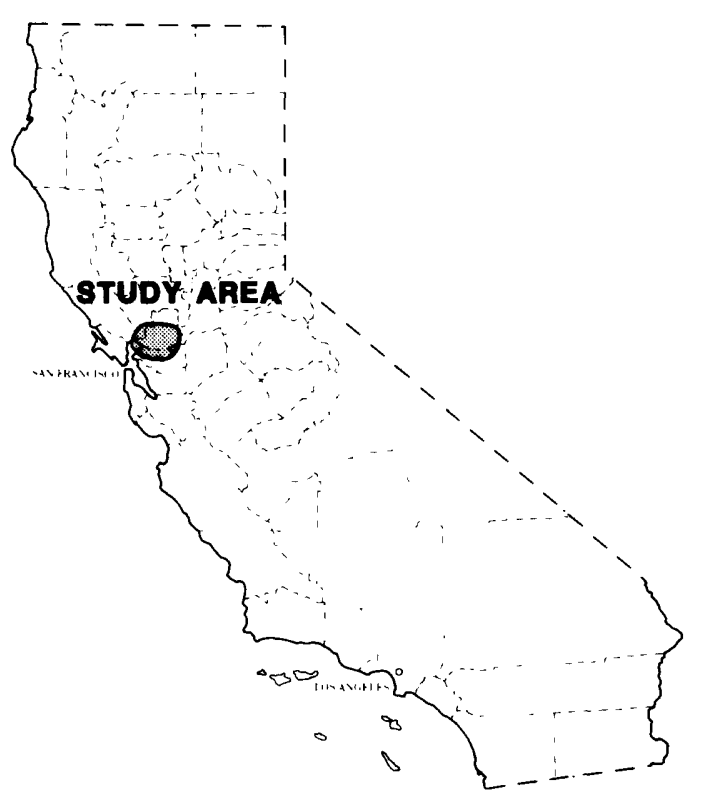

Objectives: The overall goal of this study is to better understand the factors which affect organic soil loss in the Sacramento-San Joaquin Delta. Specifically, the objectives are to: (1) quantify subsidence rates in organic soils at selected locations; (2) identify and quantitatively assess hydrologic and geochemical processes which affect carbon loss under different land- and water-management practices; and (3) assess the spatial and temporal variability of carbon loss.

Approach: An attempt will be made to quantify the processes contributing to carbon loss from the organic soils at several agricultural sites in the delta. Two of these procesśes are (1) respiration of organic carbon, and (2) dissolution and mobilization of aqueous-dissolved and particulate organic carbon. These processes will be assessed in conjunction with subsidence measurements at each site. A carbon massbalance approach will be taken at each site to reconcile subsidence with carbon loss.

\section{Progress:}

FY1990: Methods were developed for measuring gaseous carbon dioxide fluxes from organic soils. Three extensometers were installed for continuous measurement of subsidence in the organic soils. In addition to the subsidence measurements, water-table depth, air and soil temperature, barometric pressure, and wind speed were monitored continuously. Diffusive carbon dioxide fluxes and carbon-dioxide gradients are being measured monthly at 15 sites in fields adjacent to the extensometers. Soil moisture and temperature were monitored monthly at each of the gas-measurement sites. Monthly water-quality samples were collected and drain flows were measured for each field. Samples were analyzed for trace elements, dissolved organic carbon, and major ions. The ultimate objective is to relate the carbon balance to the subsidence measured by the extensometers in each field.

Subsidence rates at the three sites ranged from 0.04 to 0.13 millimeter per day. Carbon dioxide fluxes changed over time and were directly and inversely proportional to soil temperature and moisture, respectively. Carbon-dioxide fluxes ranged between 0.001 and 0.00025 gram of carbon per centimeter per day. Calculations of subsidence indicated that carbon-dioxide fluxes account for most of the subsidence at the three sites. Aqueous fluxes of carbon apparently do not contribute substantially to subsidence. 
Plans for Next Year: Continued monitoring of gaseous and aqueous carbon fluxes will allow for further refinement of the carbon budget for the individual fields. Experiments are planned that will provide information about the spatial and temporal variability of carbon-dioxide fluxes. Soil sampling and laboratory experiments will be conducted to assess processes causing spatially variable subsidence throughout the delta.

\section{Reports:}

Rojstaczer, S.A., Massey, C., Shepard, L., and Fuller, C.C., 1989, Determining the causes of San JoaquinSacramento delta elevation changes (abs.): U.S. Geological Survey Open House, November 19, 1988, 2 p. 


\section{NITRATE IN THE HEMET GROUND-WATER SUBBASIN}

Number: CA480

Cooperating Agency: Eastern Municipal Water District

Project Chief: Terry F. Rees

Period of Project: January 1990 to September 1993

Problem: Nitrate concentrations in ground water from many basins in southern California approach or exceed the drinking-water standard of 45 milligrams per liter. High nitrate concentrations are primarily due to agricultural land- and water-use practices involving, for example, dairies, citrus groves, and irrigation with reclaimed water. In order to manage the ground-water resources, and to identify future mitigating measures, the chemical, biological, and hydraulic processes that affect nitrogen speciation and concentration need to be determined for a variety of representative land-use and

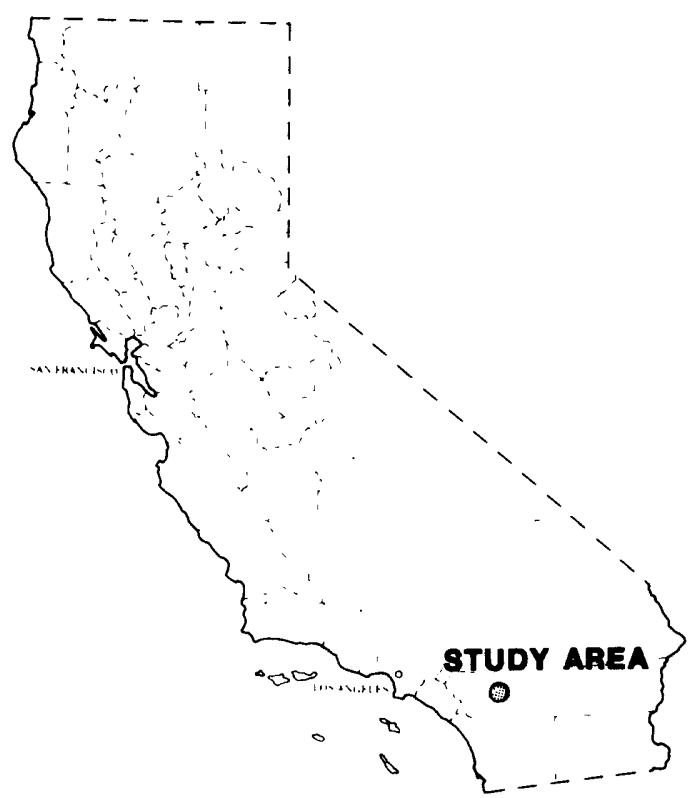
hydrologic conditions.

Objectives: Define current ground-water conditions in the Hemet subbasin, including thickness and extent of water-bearing materials, direction of ground-water flow, and chemical quality of ground water. Determine the effects of chemical, biological, and hydraulic processes on nitrogen speciation and concentration in the unsaturated zone. Determine the quantity of nitrate reaching the water table. Determine the degree of mixing and vertical distribution of nitrate in the saturated zone.

Approach: A detailed study will be done at six sites that have hydrologic and land-use conditions representative of southern California basins: (1) a residential area; (2) an area using reclaimed water; (3) a citrus grove; (4) an agricultural area; (5) a poultry operation; and (6) a dairy feedlot. Instrumentation will include neutron access tubes, suction-cup lysimeters installed above the water table, soil-gas sampling tubes, and nested piezometers installed below the water table. Physical and hydrogeological characteristics, common chemical concentrations, selected radioisotopes and stable isotopes, and bacteria will be studied.

\section{Progress:}

FY1990: The Joint Funding Agreement between the U.S. Geological Survey and the Eastern Municipal Water District initiating the study was approved June 6,1990. Six locations were selected for fully instrumented research sites: (1) a residential site owned by the city of Hemet; (2) a reclaimed water-usage site owned by Cherry Hills Golf Club in Sun City; (3) a citrus-grove site owned by Royal Citrus; (4) an agricultural site (potato field) owned by a private citizen; (5) a poultry-operation site owned by Delmer Egg Ranch; and (6) a dairy site owned by Douma's Desert Dairy. Well installation agreements between the U.S. Geological Survey and the landowners were executed between June 14 and July 26, i990. Welldrilling permits were issued by Riverside County on July 18, 1990. Utility clearances were obtained July 25, 1990. Site installations involved drilling in three phases: (1) Mud-rotary drilling during July 31 to August 24, 1990. During this phase, the deep, saturated-zone holes with multiple-depth piezometers were installed. (2) Auger drilling began September 10, 1990. Unsaturated-zone instrumentation is being installed--including suction-cup lysimeters, matric pressure transducers, neutron access tubes, gas-sampling tubes, and tensiometers. Nearly continuous cores are being collected for lithologic description and samples for soil-water chemistry and soil bacterial populations are being analyzed. (3) A second mud-rotary phase will complete the installations. 
Plans for Next Year: Auger drilling will continue until early November, and the second mud-rotary phase began November 14, 1990. Site installations will be completed by end of first quarter of fiscal year 1991. Results from the bacteria survey and lithologic description of the basin will be completed during second quarter of fiscal year 1991. The first of the soil-water chemistry samples and the saturated-zone water chemistry samples will be collected second quarter through end of fiscal year 1991 .

Reports: None. 


\section{PROCESSES GOVERNING THE DISTRIBUTION AND MOBILITY OF SELENIUM AND ARSENIC IN SHALLOW GROUND WATER, TULARE BASIN}

Number: CA481

Cooperating Agency: Califormia Department of Water Resources

\section{Project Chief: Roger Fujii}

Period of Project: October 1989 to September 1993

Problem: Large parts of the Tulare basin are being affected by shallow ground water leading to the need for subsurface drainage for continued agricultural production. Disposal of agricultural drain water in evaporation ponds and potential downward migration of contaminated, shallow ground water to regional aquifers pose threats to migratory waterfowl and human health because of the high concentrations of arsenic and selenium in the drain water. The diversity and contrast of depositional environments has contributed to the highly variable concen-

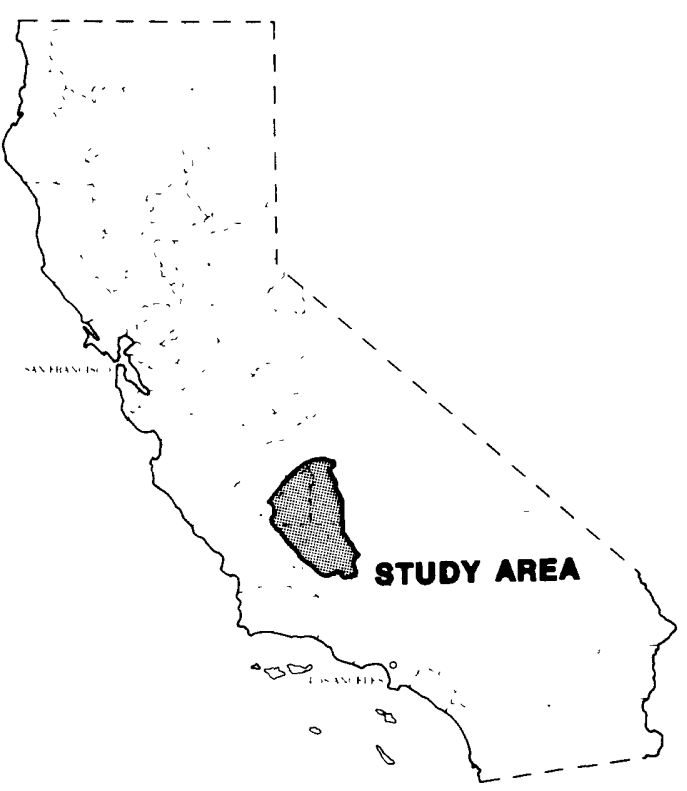
trations of arsenic and selenium in shallow ground water throughout the basin.

Objectives: Compare distribution of arsenic, selenium, and other selected elements in ground water and sediments at four locations in subareas of the Tulare basin. Identify potential geochemical, biological, and hydrologic processes controlling the solubility and mobility of arsenic and selenium at each location. Compare and contrast the potential influence of key processes between the subareas. Determine the necessary studies to comprehensively evaluate the geochemical, biological, and hydrologic processes governing solubility and mobility of arsenic and selenium for the subareas in this basin.

Approach: The distribution of arsenic and selenium in ground water and sediments will be evaluated at four locations in the basin. At each site, 20-, 50-, 100-, and 200-foot wells will be drilled and sampled. During the drilling of the 100 -foot well, a continuous core will be taken and porewater and sediments will be analyzed every 5 to 10 feet. Samples will be analyzed for arsenic, selenium, and other trace and major constituents; water levels will be monitored. These data will help define the key processes that affect the mobility of arsenic and selenium and form the basis for further studies in the basin.

\section{Progress:}

FY1990: One well cluster was drilled (20-, 50-, 100-, and 200-foot wells) in each of the four subareas in the Tulare basin. During the drilling of the 100 -foot well, continuous core was taken, and sediment and porewater were sampled every 5 to 10 feet. During the drilling of the 200 -foot wells, core samples were taken every 20 feet and sediment and porewater sampled. All wells were developed and sampled. These samples currently are being analyzed for arsenic, selenium, and other important constituents.

Plans for Next Year: Three or four well clusters will be installed along a transect to draft a geohydrologic cross section. Detailed geochemical and hydrologic data pertaining to the mobility of arsenic and selenium in sediments from the study sites will be analyzed.

Reports: None. 


\section{INTERACTION OF GROUND-WATER FLOW AT REGIONAL, SUBREGIONAL, AND FARM SCALES, AND IMPLICATIONS FOR DRAIN-WATER FLOW AND QUALITY, WESTERN SAN JOAQUIN VALLEY}

Number: CA482

Cooperating Agencies: Panoche Water and Drainage District; and California Department of Water Resources

Project Chief: John L. Fio

Period of Project: October 1989 to September 1991

Problem: In the western San Joaquin Valley, more than 250,000 acres of irrigated farmland require drainage because of severe soil salinity and a shallow water table. Shallow ground water and drain water in these areas have toxic levels of boron, molybdenum, and selenium associated with high concentrations of dissolved solids. Preliminary data indicate that ground-water flow to drainage systems in the valley and resultant contaminant loads are affected by local, subregional, and regional

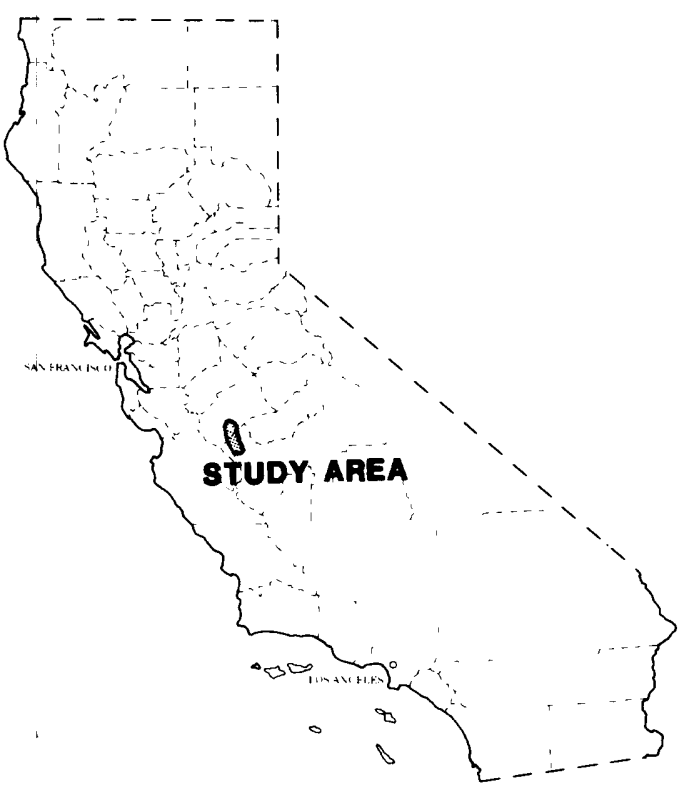
hydrologic response to stresses. Management strategies designed to control drain-water flow and quality must address the interrelations at all three scales.

Objectives: Develop and verify a subregional-scale ground-water model that simulates steady-state drain flow and drain-water chemistry. Quantitatively assess the interactions among the regional, subregional, and local ground-water-flow systems in response to irrigation and drainage. Evaluate the effects of potential local and larger-scale management actions on drain-water flow and quality. Assess implications for development of a field and modeling approach for the quantitative assessment of ground-water flow and contaminant movement in other irrigated and drained agricultural areas in which local- and regionalscale interactions must be evaluated.

Approach: A three-dimensional, finite-difference ground-water-flow model will be developed for the subregional flow system within the Panoche Water District in the western valley. Geohydrologic data from observation wells will be used to develop and calibrate the subregional model. Qualitative verification of simulated ground-water flow to the drainage systems will be made using geochemical data from ground-water and drain-water samples. Comparison of results from the subregional model and the Survey's regional-flow model of the western valley will assist the interactions between the two scales.

Progress:

FY1990: Installation of 37 observation wells was completed March 31, 1990. Twenty-five wells have 2 -foot perforated intervals at various depths between 15 to 100 feet below land surface. These wells are distributed among nine sites. The remaining 12 wells are water-table wells (perforated from 1 to 18 feet below land surface). Subsurface geology of the top 100 feet of sediments generally consisted of about 20 to 30 feet of fine-grained deposits that overlie 35 to 50 feet of coarse-grained deposits. At five of the six sites, where the deepest wells were installed, the coarse-grained deposits are underlain by 10 to 15 feet of dense clay. Ground-water samples were collected from the wells and were sent to the Central Laboratory of the U.S. Geological Survey for analysis of selenium, boron, electrical conductivity, major cations and anions, and stable isotopes. Water levels were measured bimonthly in these wells and about 30 existing wells in the study area. The data indicated that in a substantial part of the study area, irrigation recharge at the highest altitudes flows laterally downslope and upwards to discharge at the lowest 
altitudes. Data on soils, water-level measurements, drainage-system design, drain-water flows and quality, subsurface texture, and other important spatially distributed information were incorporated into a computerized geographic information system (GIS). A three-dimensional finite-difference ground-waterflow model is currently being developed for the study area.

Plans for Next Year: The ground-water-flow model will be completed and used to evaluate the chemical composition of ground water and drain water in the study area. The model also will be used to assess the interaction of the ground-water-flow system and drainage-system response to irrigation and drainage management as well as to deep well pumping.

Reports: None. 


\section{OPTIMUM CONTROL OF SEAWATER INTRUSION, OXNARD PLAIN, VENTURA COUNTY}

Number: CA483

Cooperating Agency: United Water Conservation District

Project Chief: Eric G. Reichard

Period of Project: October 1989 to September 1993

Problem: Seawater intrusion beneath the Oxnard Plain threatens the water supply in Ventura County. In order to meet future water needs, pumping from the upper aquifers probably will need to be replaced by pumping from deeper aquifers. The effects of such pumping from the deeper aquifers on the seawater-freshwater interface are uncertain. It may be possible to control seawater intrusion using a combination of controlled ground-water pumping and artificial recharge. In conjunction with a calibrated solute-transport model, hydraulic optimization

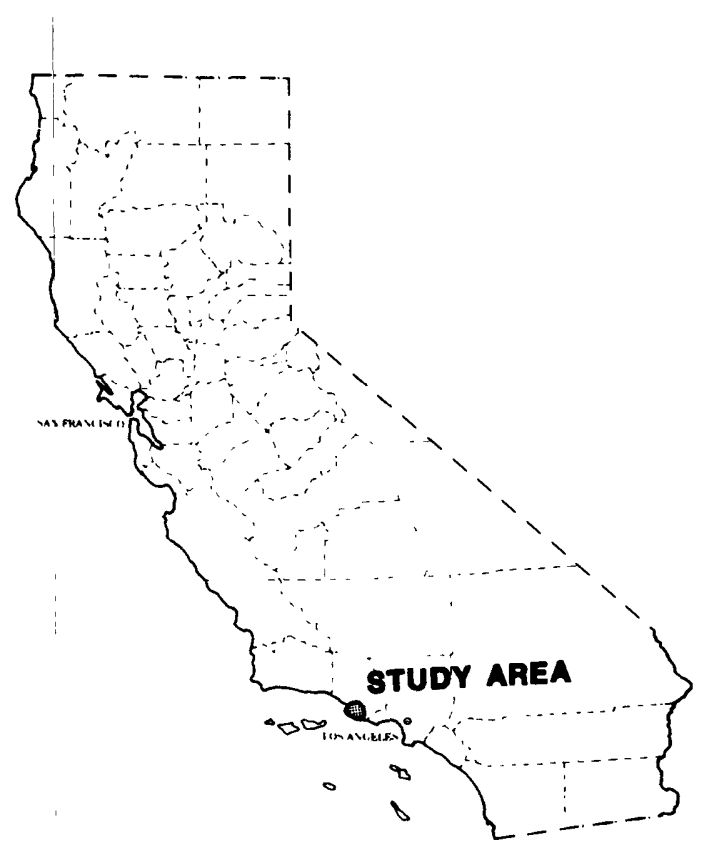
modeling would aid in evaluating the various control options.

Objectives: Apply and demonstrate the usefulness of solute-transport and hydraulic-optimization modeling techniques in evaluating various management options to control seawater intrusion in a multiaquifer system.

Approach: The study tasks are to drill and collect data from nested test wells in the Oxnard Plain, to analyze the data to develop a conceptual model of the three-dimensional geohydrologic system, to develop a three-dimensional transport model of seawater intrusion, and to develop a set of simulation-management models for evaluating alternative strategies for controlling seawater intrusion.

\section{Progress:}

FY1990: In the first year of study, a cluster of 11 monitoring wells were drilled in the Oxnard Plain area. Water-level and water-quality data were collected at all the wells. The geologic and geophysical logs from each well, along with geophysical data from existing wells, provide the basis for developing a conceptual model of the three-dimensional geohydrologic system. In conjunction with the Southern California RASA (Regional Aquifer-System Analysis) program, hydrologic data from relevant agencies were compiled and entered into a geographic information system (GIS). Data include water levels, water quality, and pumping rates. A simplified simulation model of ground-water flow in the Santa Clara Calleguas basin was developed. The model is based on a previous model by the California Department of Water Resources.

Plans for Next Year: A preliminary simulation-management model linking the ground-water-flow model with a mathematical optimization program will be developed. A multilayer sharp-interface model will be formulated to simulate seawater intrusion. Several additional nested monitoring wells will be drilled.

Reports: None. 


\section{SAN FRANCISCO BAY-ESTUARY TOXIC CONTAMINANT STUDY}

Number: CA484

Cooperating Agency: None. (U.S. Geological Survey
Federal Program)

Project Chief: Kathryn M. Kuivila

Period of Project: March 1990 to September 1995

Problem: Estuaries are among the most heavily used of the Nation's surface-water resources and are particularly susceptible to contamination by toxic substances. The San Francisco Bay estuary receives a broad range of organic contaminants that vary widely in their sources, seasonality, toxicity, and environmental behavior. Despite an increasing awareness of potential contamination issues, the effect of organic contaminants in the estuarine environment is not fully understood.

Objectives: Determine how organic contaminants from

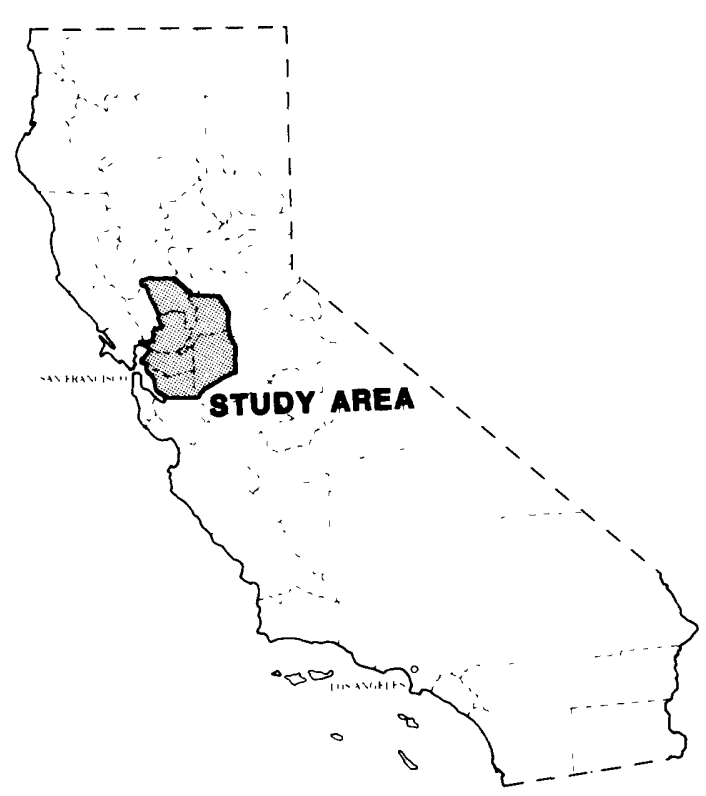
riverine and local sources are transported and react in the estuary under varying hydrologic conditions. Determine the ultimate fate of these organic contaminants within the estuary. Develop methods to detect and quantify ecological responses to the presence of organic contaminants in the estuary.

Approach: Present data on pesticide use and waste discharges will be synthesized to select specific organic contaminants for sampling and analysis. Various sampling techniques will be used, including fixed-site monitoring and synoptic studies to provide a consistent record of river-transported contaminants. Certain hypotheses on contaminant distribution during specific hydrologic and contaminant-loading conditions will be tested. Bottom sediment and biota will be collected and analyzed to define the distribution of these contaminants and their partitioning between water, sediment, and biota.

\section{Progress:}

FY1990: The transport and degradation of four dissolved rice pesticides in the Sacramento River and delta were investigated in a reconnaissance study. The primary sources of these pesticides were upstream of the city of Sacramento, which was the beginning location of this study. A Lagrangian sampling scheme was used whereby samples were taken every 6 hours while using a drogue to follow a "parcel" of water down the river to Rio Vista. Three of the pesticides (molinate, thiobencarb, and carbofuran) and the degradation products of molinate and carbofuran were detected throughout the study reach. Although methyl parathion was not detected in any of the samples, a degradation product, para-nitro phenol, was detected at all sampling sites. Laboratory experiments are in progress to measure both chemical and microbiological degradation rates of all four pesticides. Pesticide-use records for the Central Valley were analyzed to evaluate which pesticides are potentially important contaminants and to determine their seasonal and spatial distribution. A detailed, 5-year workplan was developed, which includes overall sampling and analytical schemes and incorporates more specific research projects.

Plans for Next Year: Different methods for sampling suspended sediment and associated pesticides will be tested in the null zone. Following a dye study to determine route and traveltime, a Lagrangian sampling scheme will be used to follow a "parcel" of water for almond pesticides from Vemalis through the delta in February. Because the source of alfalfa pesticides is from the San Joaquin River and within the delta, several sites in the delta will be routinely sampled for alfalfa pesticides in April. The concentrations of rice pesticides will be measured over time at both ends of Suisun Bay, Chipps Island, and Carquinez Strait.

Reports: None. 


\section{WATER RESOURCES OF INDIAN RESERVATIONS IN CALIFORNIA}

Number: CA487

Cooperating Agency: Pala Band of Mission Indians

Project Chief: James C. Blodgett

Period of Project: July 1990 to September 1993

Problem: About 40 small Indian reservations in California from time to time request assistance in assessing their reservation's water resources. The ability for the U.S. Geological Survey to respond to these requests is dependent on availability of qualified personnel. Commonly, this will involve a low-level reconnaissance study to determine the potential of surface or ground water for development or simply to suggest sites where small supplies of good quality water can be found.

Objectives: Provide water-resource appraisals of Indian reservations in California. Because the reservations

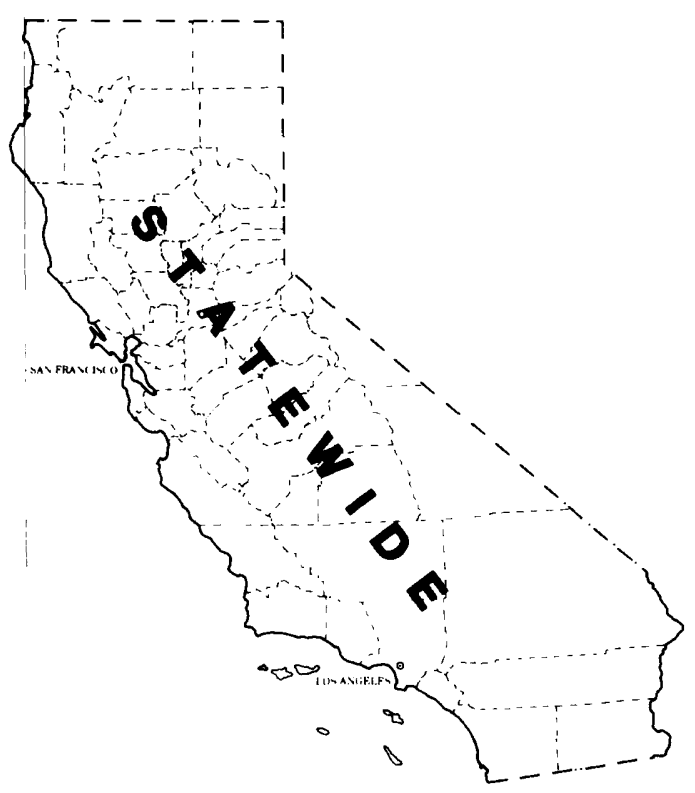
generally are small (some having only tens of people), the work to be done on each reservation will be limited to reconnaissance level, qualitative hydrology, and well-site selection. Where present or future potential water needs are large, areas beyond the reservation may be evaluated.

Approach: As necessary, wells will be inventoried, streams will be measured, water quality will be determined, and favorable sites for development will be located. Limited geologic mapping will be done if not already available. When warranted, shallow augering will be done, and if necessary, test holes may be drilled. Preliminary hydrologic models may be developed to assist in data analyses and interpretation.

\section{Progress:}

FY1990: A study to determine surface-water runoff characteristics in the Bubble-up Creek drainage basin in the Pala Indian Reservation, San Diego County was started in August 1990. A continuous-recording streamgage and a rain gage were installed on Bubble-up Creek, about 1 mile upstream from San Luis Rey River flood plain. A continuous-recording streamgage was reactivated on Keys Creek Tributary at Valley Creek. A new recording rain gage also was installed at this streamgage site. Rainfall and water-discharge data for water years 1971 to 1982 were used to develop a rainfall-runoff model of the Keys Creek Tributary drainage basin. A frequency analysis was made on rainfall data from 1948 to 1983 at National Weather Service stations at Fallbrook, Lake Wohlford, and Henshaw Dam to determine the intensity and variability of local rainfall. Rainfall duration and intensity from the frequency analysis will be used to design storm input for a future rainfall-runoff model for the Bubble-up Creek drainage basin.

Plans for Next Year: The stream and rain gages on Bubble-up Creek and Keys Creek Tributary will be operated from November to May. Water samples from Bubble-up Creek will be collected and analyzed for major ions and trace metals for each major runoff event. A preliminary rainfall-runoff model will be developed for the Bubble-up Creek drainage basin. Soil moisture and infiltration parameters from the Keys Creek model will be used in the preliminary Bubble-up model.

Reports: None. 


\section{ASSESSMENT OF THE EFFECTS OF POTENTIAL CLIMATE CHANGE ON THE WATER RESOURCES OF THE CARSON, AMERICAN, AND TRUCKEE RIVER BASINS}

Number: CA488

Cooperating Agency: None.

Project Chief: Lowell F.W. Duell, Jr.

Period of Project: March 1990 to September 1993

Problem: Changes in the current climatic regime could have significant effects on the type, amount, and timing of precipitation and runoff in the Carson, American, and Truckee River basins. Significant changes could result in far-reaching effects on hydrologic processes, biota, water management, and water use.

Objectives: Define the effects of possible climate change on the water resources of the Carson, American, and Truckee River basins and develop analytical tools for analysis of the effects of climate change on water

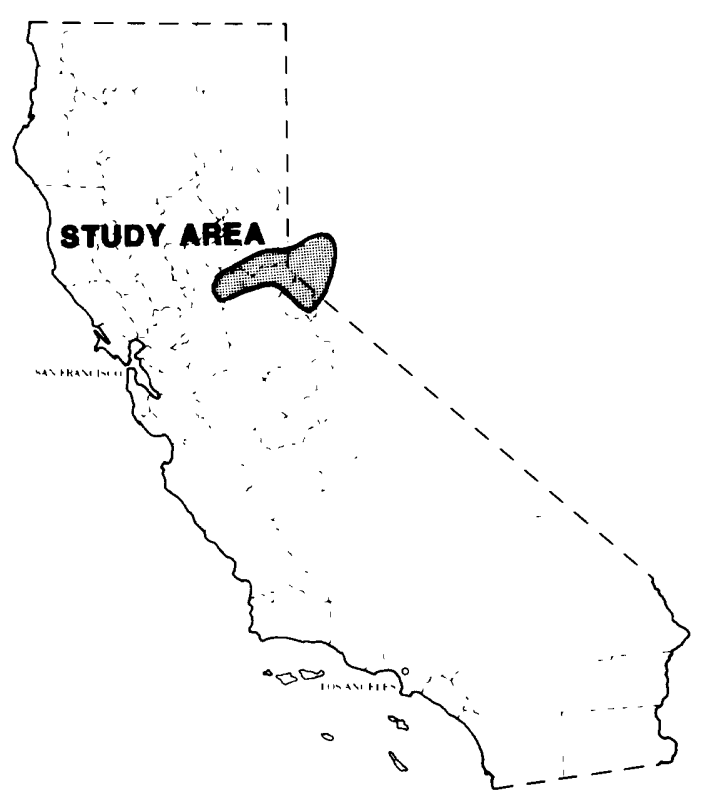
resources.

Approach: The study will be a joint effort between the California and Nevada Districts. The general approach is to define current climate and develop future climate scenarios, develop a data base to support watershed modeling of the three basins, and model watershed processes for current and future scenarios. Specifically, project personnel in the California District will (1) determine unregulated streamflow for the three basins; (2) link the unregulated streamflow to climate data and do stochastic analysis; and (3) develop climate scenarios.

\section{Progress:}

FY1990: Surface-water-site inventories for the three basins were completed, and development of the surface-water data base and literature review began.

Plans for Next Year: Data base using geographic information system and climate scenarios will be developed. Stochastic analysis for streamflow will be done and development of drainage basin models will begin.

Reports: None. 


\section{CHARACTERIZATION OF THE QUALITY OF WATER RESOURCES OF SANTA CLARA COUNTY}

Number: CA490

Cooperating Agency: Santa Clara Valley Water District

Project Chief: Vacant

Period of Project: Continuing

Problem: The Santa Clara Valley Water District (SCVWD) is concerned with the behavior of contaminants in the reservoirs, streams, and aquifers which serve to store, convey, and treat its water. These contaminants include taste and odor causing algae imported with Central Valley Project water; trace elements in surfacewater runoff from mine tailings, and nitrate in ground water from the application of fertilizers to agricultural lands. The presence of these contaminants in the hydrologic system requires an understanding of the processes that control their mobility and distribution to ensure

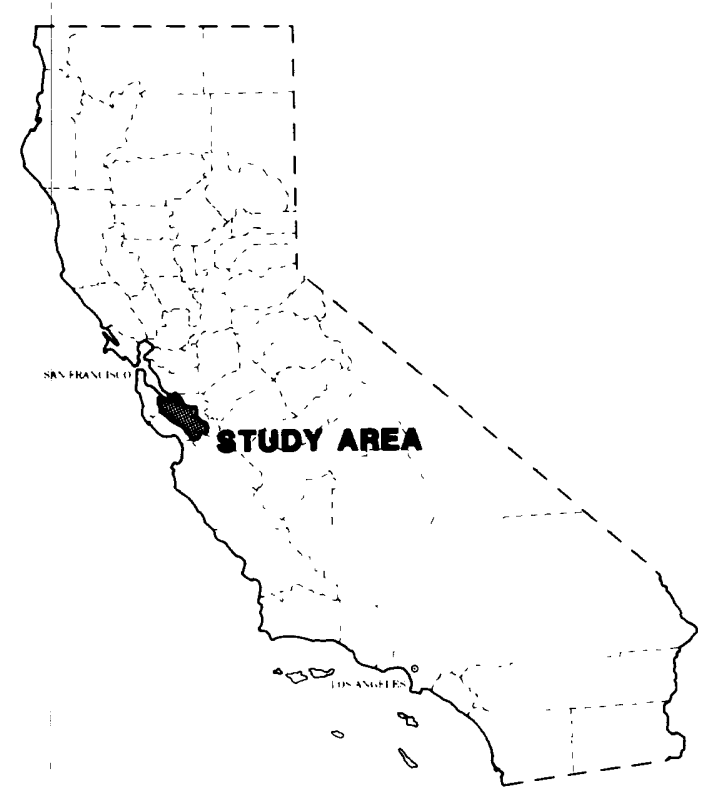
adequate protection of the water supply.

Objectives: General study objectives are to characterize surface- and ground-water quality, assess processes controlling contaminant transport, and design hydrologic monitoring networks.

Approach: (1) Maintain an optimum surface-water quality monitoring network; (2) determine the processes controlling the mobility of trace elements in the streams, reservoirs, and percolation ponds in the Guadalupe River drainage; (3) determine the processes controlling the dynamics of the algal blooms responsible for taste and odor problems in Calero Reservoir, and (4) design a ground-water monitoring network for the Llagas-Bolsa subbasins.

\section{Progress:}

FY1988: Water-quality monitoring for streams and reservoirs was continued, but limited by the lack of appreciable runoff. A preliminary analysis of the effects of the 1985 Los Gatos fire on the water quality of Lexington Reservoir was discussed with the cooperator. A summary report on data collected to date and on the analysis of the effects from the fire for Lexington Reservoir will be prepared in fiscal year 1989.

FY1989: A second consecutive dry precipitation year limited stream-quality monitoring to two low-flow samplings. Monitoring in Calero Reservoir was resumed to evaluate effects of importing water from the San Felipe Division of the Central Valley Project. Water year 1988 was the first year San Felipe Division water was stored in Calero Reservoir. Water-quality samples were collected near the dam and at the outlet of the San Felipe pipeline in April, June, July, and August during algal-bloom conditions. Algal blooms also occurred in San Luis Reservoir, the source water of the San Felipe Division. Monitoring also included April, June, July, and August samples at Uvas Reservoir. Minimum storage conditions, resulting from the second consecutive dry year, prevented planned water-quality sampling at Coyote, Almaden, and Guadalupe Reservoirs. A review draft of a report on water quality of Lexington Reservoir with an emphasis on an analysis of the effects from the 1985 Los Gatos fire was prepared. A preliminary analysis of available data in the Llagas-Bolsa subbasin was started toward the design of a ground-water monitoring network. 
FY1990: Monitoring in Calero Reservoir was continued. Response to reviews of the Lexington Reservoir report was completed, and the report was submitted for publication approval. A data base of qualified data from the Llagas-Bolsa subbasin was established. A proposed ground-water monitoring network and analysis program was prepared. A reconnaissance of the area receiving surface-water runoff from mine tailings in the Los Capitancillos Hills, about 2 miles south of San Jose, was done and a site where trace elements will be sampled over storm hydrographs during the wet winter season was identified. Streamwater-quality monitoring again was limited by dry conditions. Runoff for three minor storms and one low-flow condition were sampled.

Plans for Next Year: Samples will be collected from anoxic reservoir bottom waters, streams below the reservoir outlets, and percolation ponds downstream from the reservoirs during the dry summer season. Limnological data will be collected on Calero Reservoir during periods of algal blooms. Algal species responsible for blooms and any taste and odor problems will be identified. An attempt will be made to relate the physical, chemical, and biological data to bloom periods and intensities. Algal population dynamics will be related to the applications of copper sulfate and import of water from San Luis Reservoir.

Historical ground-water data will be entered into a Geographical Information System (GIS) developed for the Llagas-Bolsa subbasin. A conceptual model of the basin will be developed following a thorough literature review. The conceptual model will be represented numerically using the MacDonald-Harbough finite-difference modeling package and calibrated through comparison with data entered into the GIS. The results of the comparison will be used to redesign the monitoring network to assess hydraulic heads and the quality of the ground water in the basin. Data collected from the network will then be used to update the GIS and refine the flow model.

Reports: None. 


\section{BIBLIOGRAPHY}

\section{REPORTS FOR CALIFORNIA PUBLISHED IN 1988, 1989, AND 1990}

Anderson, S.W., Hunter, T.C., and Mullen, J.R., 1990, Water resources data--California, water year 1989. Volume 3. Southern Central Valley basins and the Great Basin from Walker River to Truckee River: U.S. Geological Survey Water-Data Report CA-89-3, 417 p.

Anderson, S.W., Markham, K.L., Shelton, W.F., and Trujillo, L.F., 1988, Water resources data--California, water year 1986. Volume 2. Pacific slope basins from Arroyo Grande to Oregon State line except Central Valley: U.S. Geological Survey Water-Data Report CA-86-2, 371 p.

Anderson, S.W., Markham, K.L., Shelton, W.F., and Trujillo, L.F., 1988, Water resources data--California, water year 1987. Volume 2. Pacific slope basins from Arroyo Grande to Oregon State line except Central Valley: U.S. Geological Survey Water-Data Report CA-87-2, 315 p.

Anderson, S.W., Mullen, J.R., and Shelton, W.F., 1990, Water resources data-- California, water year 1989. Volume 4. Northern Central Valley basins and the Great Basin from Honey Lake Basin to Oregon State line: U.S. Geological Survey Water-Data Report CA-89-4, 315 p.

Anttila, P.W., 1988, U.S. Geological Survey ground-water studies in California: U.S. Geological Survey Open-File Report 88-159, 2 p. (Water Fact Sheet)

Beard, Sherrill, and Laudon, Julie, 1988, Data for ground-water test holes in Fresno County, western San Joaquin Valley, California, June to August 1985: U.S. Geological Survey Open-File Report 88-78, 39 p.

Belitz, Kenneth, and Heimes, F.J., 1990, Character and evolution of the ground-water flow system in the central part of the western San Joaquin Valley, California: U.S. Geological Survey Water-Supply Paper 2348, 28 p.

Berenbrock, Charles, 1988, Ground-water quality in the Lompoc plain, Santa Barbara County, California, 1983: U.S. Geological Survey Water-Resources Investigations Report 87-4101, 54 p.

Bertoldi, G.L., 1989, Ground-water resources of the Central Valley of California: U.S. Geological Survey Open-File Report 89-251, 2 p. (Water Fact Sheet).

Blodgett, J.C., 1989, Assessment of hydraulic changes associated with removal of Cascade Dam, Merced River, Yosemite Valley, California: U.S. Geological Survey Open-File Report 88-733, 15 p.

Blodgett, J.C., 1989, Monitoring channel scour at the SR-32 bridge across the Sacramento River at Hamilton City, California (abs.): Bridge Scour Symposium, McLean, Virginia, October 17-19, 1989, 2 p.

Blodgett, J.C., and Chin, E.H., 1989, Flood of January 1982 in the San Francisco Bay area, California: U.S. Geological Survey Water-Resources Investigations Report 88-4236, 46 p.

Blodgett, J.C., Ikehara, M.E., and McCaffrey, W.F., 1988, Determination of bench-mark elevations at Bethel Island and vicinity, Contra Costa and San Joaquin Counties, California, 1987: U.S. Geological Survey Open-File Report 88-498, 11 p.

Blodgett, J.C., Ikehara, M.E., and Williams, G.E., 1988, Land subsidence monitoring in the Sacramento Valley using global positioning system surveys (abs.): American Society of Civil Engineers Specialty Conference GPS-88, Nashville, Tennessee, May 11-14, 1 p. 
Blodgett, J.C., Ikehara, M.E., and Williams, G.E., 1990, Monitoring land subsidence in Sacramento Valley, California, using GPS: American Society of Civil Engineers Journal of Surveying Engineering, v. 116, no. 2, p. 112-130.

Blodgett, J.C., and Lucas, J.B., 1988, Profile of Sacramento River, Freeport to Verona, California, flood of February 1986: U.S. Geological Survey Open-File Report 88-82, 16 p.

Blodgett, J.C., Nasseri, Iraj, and Elliott, A.L., 1990, Urban hydrology in the desert, Antelope Valley, California: American Society of Civil Engineers, Hydraulics/Hydrology of Arid Lands, San Diego, Proceedings, p. 96-101.

Blodgett, J.C., and Poeschel, K.R., 1988, Peak discharge, volume, and frequency of the January 1982 flood in the Santa Cruz Mountains and vicinity, in Ellen, S.D., and Wieczorek, G.F., eds., Landslides, floods, and marine effects of the storm of January 3-5, 1982, in the San Francisco Bay region, California: U.S. Geological Survey Professional Paper 1434, p. 229-243.

Blodgett, J.C., Poeschel, K.R., and Thornton, J.L., 1988, A water-resources appraisal of the Mount Shasta area in northem California, 1985: U.S. Geological Survey Water-Resources Investigations Report $87-4239,46 \mathrm{p}$.

Borchers, J.W., 1988, Stress relief fracture controlled ground-water flow systems of the Appalachian Plateaus: Eos, Transactions of the American Geophysical Union, Abstracts, v. 69, no. 44, p. 1172.

Bowers, J.C., 1990, Potential hazards from floodflows in Grapevine Canyon, Death Valley National Monument, California and Nevada: U.S. Geological Survey Water-Resources Investigations Report 89-4063, 19 p.

Bowers, J.C., McConaughy, C.E., Polinoski, K.G., and Smith, G.B., 1988, Water resources data--California, water year 1987. Volume 1. Southern Great Basin from Mexican border to Mono Lake basin and Pacific slope basins from Tijuana River to Santa Maria River: U.S. Geological Survey Water-Data Report CA-87-1, 303 p.

Branson, F.A., Miller, R.F., and Sorenson, S.K., 1988, Tolerances of plants to drought and salinity in the Western United States: U.S. Geological Survey Water-Resources Investigations Report 88-4070, $16 \mathrm{p}$.

Burau, J.R., and Cheng, R.T., 1988, Predicting tidal currents in San Francisco Bay using a spectral model, in International Symposium on Model-Prototype Correlation: American Society of Civil Engineers, Hydraulics Division, Colorado Springs, Colorado, Proceedings, p. 634-639.

Burau, J.R., and Cheng, R.T., 1989, A general method for generating bathymetric data for hydrodynamic computer models: U.S. Geological Survey Open-File Report 89-28, 45 p.

Burau, J.R., and Cheng, R.T., 1989, A vertically averaged spectral model for tidal circulation in estuaries: Part 1. Model formulation: U.S. Geological Survey Water-Resources Investigations Report $88-4126,31 \mathrm{p}$.

Cheng, R.T., and Burau, J.R., 1988, System considerations in numerical modeling of estuarine problems: International Conference on Numerical Methods in Flow Problems, Okayama, Japan, September 4-8, Proceedings, 8 p.

Cheng, R.T., Burau, J.R. and Gartner, J.W., 1988, Interfacing data analysis and numerical modeling for tidal hydrodynamics phenomena, in International Conference on Tidal Hydrodynamics: Gaithersburg, Maryland. 
Cheng, R.T., and Smith, P.E., 1990, A survey of three-dimensional numerical estuarine models: American Society of Civil Engineers, Estuarine and Coastal Modeling, Newport, Rhode Island, November 15-17, 1989, p. 1-15.

Clifton, D.G., and Gilliom, R.J., 1989, Sources and concentrations of dissolved solids and selenium in the San Joaquin River and its tributaries, California, October 1985 to March 1987: U.S. Geological Survey Water-Resources Investigations Report 88-4217, 33 p.

Clifton, D.G., and Gilliom, R.J., 1989, Trace elements in bed sediments of the San Joaquin River and its tributary streams, California, 1985: U.S. Geological Survey Water-Resources Investigations Report 88-4169, 33 p.

Danskin, W.R., 1988, Preliminary evaluation of the hydrogeologic system in Owens Valley, California: U.S. Geological Survey Water-Resources Investigations Report 88-4003, 76 p.

Danskin, W.R., 1989, Hydrogeologic facies modeling applied to a basin and range aquifer system: Eos, Transactions of the American Geophysical Union, Abstracts, v. 70, no. 43, p. 1098.

Danskin, W.R., and Freckleton, J.R., 1989, Ground-water-flow modeling and optimization techniques applied to high-ground-water problems in San Bemardino, California: U.S. Geological Survey Open-File Report 89-75, 14 p.

Deverel, S.J., 1988, Geohydrologic aspects of water-quality problems of the San Joaquin Valley, California: American Society of Civil Engineers, National Irrigation and Drainage Division Conference on Planning Now for Irrigation and Drainage, Lincoln, Nebraska, July 18-21, Proceedings, p. 694-699.

Deverel, S.J., 1988, Hydrologic processes affecting the distribution and mobility of salinity and selenium in shallow ground water, western San Joaquin Valley, California: American Society of Agronomy, 1988 California Plant and Soil Conference, Fresno, California, Proceedings, p. 1-3.

Deverel, S.J., 1989, Geostatistical and principal-component analyses of groundwater chemistry and soil-salinity data, San Joaquin Valley, California, in Stephen Ragone, ed., Regional characterization of water quality: International Association of Hydrologic Sciences, Publication No. 182 , p. 11-18.

Deverel, S.J., 1990, Distribution and mobility of trace constituents associated with irrigated agriculture in the Western United States (abs.): American Association for the Advancement of Science, Pacific Division, 71st, Davis, Califomia, v. 9, part 1, p. 33.

Deverel, S.J., and Bell, R.B., 1988, Carbon mass transfer and isotopic evolution in shallow ground water, San Joaquin Valley, Califomia: Eos, Transactions of the American Geophysical Union, Abstracts, v. 69, no. 44, p. 1194.

Deverel, S.J., and Fio, J.L., 1989, Application of oxygen-18 and deuterium data to the understanding of selenium transport to agricultural drainage systems, San Joaquin Valley, California: Eos, Transactions of the American Geophysical Union, Abstracts, v. 70, no. 43, p. 1382.

Deverel, S.J., and Fio, J.L., 1990, Ground-water flow and solute movement to drain laterals, westem San Joaquin Valley, California. 1. Geochemical assessment: U.S. Geological Survey Open-File Report 90-136, 23 p.

Deverel, S.J., and Fujii, Roger, 1988, Processes affecting the distribution of selenium in shallow groundwater of agricultural areas, westem San Joaquin Valley, California: Water Resources Research, v. 24, no. 4, p. 516-524. 
Deverel, S.J., and Fujii, Roger, 1990, Chemistry of trace elements in soils and ground water, chap. 4 in Tanji, K.K., ed., Agricultural salinity assessment and management: American Society of Civil Engineers Manuals and Reports on Engineering Practice No. 71, p. 64-90.

Deverel, S.J., and Gallanthine, S.K., 1989, Relation of salinity and selenium in shallow groundwater to hydrologic and geochemical processes, western San Joaquin Valley, California: Journal of Hydrology, v. 109, p. 125-149.

Deverel, S.J., and Millard, S.P., 1988, Distribution and mobility of selenium and other trace elements in shallow groundwater of the western San Joaquin Valley, California: Environmental Science and Technology, v. 22, no. 6, p. 697-702.

Dileanis, P.D., and Groeneveld, D.P., 1989, Osmotic potential and projected drought tolerance of four phreatophytic shrub species in the Owens Valley, California: U.S. Geological Survey Water-Supply Paper 2370-D, 21 p.

Domagalski, J.L., and Eugster, H.P., 1988, Comparison of organic geochemistry at Great Salt, Walker, and Mono Lakes: Eos, Transactions of the American Geophysical Union, Abstracts, v. 69, no. 44, p. $1121-1122$.

Domagalski, J.L, Eugster, H.P., and Jones, B.F., 1989, Controls on trace metal distribution in closed-basin lakes: Eos, Transactions of the American Geophysical Union, Abstracts, v. 70, no. 43, p. 1102.

Domagalski, J.L., Orem, W.H., and Eugster, H.P., 1989, Organic geochemistry and brine composition in Great Salt, Mono, and Walker Lakes: Geochimica et Cosmochimica Acta, v. 53, no. 11, p. 2857-2872.

Dubrovsky, N.M., and Neil, J.M., 1988, Processes that control selenium distribution in ground water, western San Joaquin Valley, California: Eos, Transactions of the American Geophysical Union, Abstracts, v. 69, no. 16, p. 364.

Dubrovsky, N.M., Neil, J.M., and Fujii, Roger, 1988, Possible redox control of selenium transport in a complex stratigraphic setting in the San Joaquin Valley, California: Eos, Transactions of the American Geophysical Union, Abstracts, v. 69, no. 44, p. 1181.

Dubrovsky, N.M., Neil, J.M., Fujii, Roger, Oremland, R.S., and Hollibaugh, J.T., 1990, Influence of redox potential on selenium distribution in ground water, Mendota, western San Joaquin Valley, California: U.S. Geological Survey Open-File Report 90-138, 24 p.

Duell, L.F.W., Jr., and Schroeder, R.A., 1989, Appraisal of ground-water quality in the Bunker Hill basin of San Bernardino Valley, California: U.S. Geological Survey Water-Resources Investigations Report 88-4203, 69 p.

Duell, L.F.W., Jr., 1990, Estimates of evapotranspiration in alkaline scrub and meadow communities of Owens Valley, California, using the Bowen-ratio, eddy-correlation, and Penman-combination methods: U.S. Geological Survey Water-Supply Paper 2370-E, 39 p.

Duell, L.F.W., Jr., 1990, Water resources of the Descanso area, San Diego County, California: U.S. Geological Survey Water-Resources Investigations Report 90-4014, 26 p.

Farrar, C.D., and Bertoldi, G.L., 1988, Region 4, Central Valley and Pacific Coast Ranges, in Back, William, Rosenshein, J.S., and Seaber, P.R., eds., Hydrogeology, v. O-2 of The Geology of North America: Boulder, Colorado, Geological Society of America, p. 59-67. 
Farrar, C.D., and Lyster, D.L., 1990, Monitoring the hydrologic system for potential effects of geothermal and ground-water development in the Long Valley caldera, Mono County, California, U.S.A.: Geothermal Resources Council, 1990 International Symposium on Geothermal Energy, Kailua Kona, Hawaii, August 20-24, Transactions, v. 14, part 1, p. 669-674.

Farrar, C.D., Sorey, M.L., Rojstaczer, S.A., Steinemann, A.C., and Clark, M.D., 1989, Hydrologic and geochemical monitoring in Long Valley caldera, Mono County, California, 1986: U.S. Geological Survey Water-Resources Investigations Report 89-4033, 69 p.

Fio, J.L., and Deverel, S.J., 1988, Ground-water flow to subsurface agricultural drains in the western San Joaquin Valley, California: Eos, Transactions of the American Geophysical Union, Abstracts, v. 69 , no. 44 , p. 1188 .

Fio, J.L., and Deverel, S.J., 1989, Ground-water flow to subsurface agricultural drains in the western San Joaquin Valley, California, in Pederson, G.L., and Smith, M.M., compilers, U.S. Geological Survey Second National Symposium on Water Quality: Abstracts of the Technical Sessions, Orlando, Florida, November 17-19: U.S. Geological Survey Open-File Report 89-409, p. 25.

Fio, J.L., and Deverel, S.J., 1990, Ground-water flow and solute movement to drain laterals, western San Joaquin Valley, California. 2. Quantitative hydrologic assessment: U.S. Geological Survey Open-File Report 90-137, 15 p.

Fio, J.L., and Deverel, S.J., 1990, Interaction of shallow ground water and subsurface drains: Implications for selenium transport and distribution in the western San Joaquin Valley, California: Ground Water, v. 28 , no. 5 , p. $788-789$.

Fio, J.L., and Fujii, Roger, 1990, Selenium speciation methods and application to soil saturation extracts from San Joaquin Valley, California: Soil Science Society of America Journal, v. 54, no. 2, p. 363-369.

Fio, J.L., Fujii, Roger, and Deverel, S.J., 1990, Evaluation of selenium mobility in soil using sorption experiments and a numerical model, western San Joaquin Valley, California: U.S. Geological Survey Open-File Report 90-135, 13 p.

Freckleton, J.R., 1989, Geohydrology of the Foothill ground-water basin near Santa Barbara, California: U.S. Geological Survey Water-Resources Investigations Report 89-4017, 46 p.

Fujii, Roger, 1988, Speciation of soluble and adsorbed selenium in soils, western San Joaquin Valley, California: Eos, Transactions of the American Geophysical Union, Abstracts, v. 69, no. 44, p. 1182.

Fujii, Roger, 1988, Water-quality and sediment-chemistry data of drain water and evaporation ponds from the Tulare Lake Drainage District, Kings County, California, March 1985 to March 1986: U.S. Geological Survey Open-File Report 87-700, 19 p.

Fujii, Roger, 1989, Speciation of soluble and adsorbed selenium in soils, western San Joaquin Valley, California, in Pederson, G.L., and Smith, M.M., compilers, U.S. Geological Survey Second National Symposium on Water Quality: Abstracts of the Technical Sessions, Orlando, Florida, November 17-19: U.S. Geological Survey Open-File Report 89-409, p. 28.

Fujii, Roger, and Burau, R.G., 1989, Estimation of adsorbed Se(IV) in soils, western San Joaquin Valley, Califormia: American Society of Agronomy, Annual Meeting, Las Vegas, Nevada, Agronomy Abstracts, December, p. 200. 
Fujii, Roger, and Deverel, S.J., 1989, Mobility and distribution of selenium and salinity in groundwater and soil of drained agricultural fields, western San Joaquin Valley of California, in Jacobs, L.W., and others, eds., Selenium in agriculture and the environment: Soil Science Society of America Special Publication No. 23, p. 195-212.

Fujii, Roger, Deverel, S.J., and Hatfield, D.B., 1988, Distribution of selenium in soils of agricultural fields, western San Joaquin Valley, California: Soil Science Society of America Journal, v. 52, no. 5, p. $1274-1283$.

Fujii, Roger, and Fio, J.L., 1988, Partitioning and speciation of soluble and adsorbed selenium in soils (abs.): American Society of Agronomy, 80th Annual Meeting, Anaheim, California, Agronomy Abstracts, November 27-December 2, p. 197-198.

Fujii, Roger, and Lipton, D.S., 1990, Mobility and solid-phase distribution of selenium in soils, western San Joaquin Valley, California (abs.): American Association for the Advancement of Science, Pacific Division, 71st, Davis, California, v. 9, part 1, p. 36.

Gartner, J.W., and Oltmann, R.N., 1990, Comparison of recording meters in shallow waters of San Francisco Bay, California: U.S. Geological Survey Water-Resources Investigtions Report 90-4018, 84 p.

Gartner, J.W., and Yost, B.T., 1988, Tides, and tidal and residual currents in Suisun and San Pablo Bays, California, results of measurements, 1986: U.S. Geological Survey Water-Resources Investigations Report 88-4027, 94 p.

Gilliom, R.J., 1988, Source and distribution of selenium in ground water, western San Joaquin Valley, California: Eos, Transactions of the American Geophysical Union, Abstracts, v. 69, no. 16, p. 364.

Gilliom, R.J., 1989, Selenium in the San Joaquin Valley: Sources, distribution, and mobility: U.S. Geological Survey Yearbook, Fiscal Year 1988, p. 30-34.

Gilliom, R.J., and Clifton, D.G., 1990, Organochlorine pesticide residues in bed sediments of the San Joaquin River, California: Water Resources Bulletin, v. 26, no. 1, p. 11-24.

Gilliom, R.J., and Hill, B.R., 1989, Improvements in estimating trace-element loads using daily suspended-sediment data, San Joaquin River, California: Eos, Transactions of the American Geophysical Union, Abstracts, v. 70, no. 43, p. 1106.

Gilliom, R.J., and others, 1989, Preliminary assessment of sources, distribution, and mobility of selenium in the San Joaquin Valley, California: U.S. Geological Survey Water-Resources Investigations Report 88-4186, 129 p.

Gronberg, J.M., 1989, Data processors for use in ground-water modeling: American Society of Civil Engineers, Water Resources Planning and Management, 16th Annual Conference, Proceedings, 3 p.

Gronberg, J.M., Belitz, Kenneth, and Phillips, S.P., 1990, Distribution of wells in the central part of the western San Joaquin Valley, California: U.S. Geological Survey Water-Resources Investigations Report 89-4158, 51 p.

Guay, Joel, R., 1990, Simulation of urban runoff and river water quality in the San Joaquin River near Fresno, California: American Water Resources Association, Symposium on Urban Hydrology, Denver, Colorado, November 1990, Proceedings, 5 p. 
Guay, J.R., and Smith, P.E., 1988, Simulation of quantity and quality of storm runoff for urban catchments in Fresno, California: U.S. Geological Survey Water-Resources Investigations Report $88-4125,76 \mathrm{p}$.

Guymon, G.L., and Yen, Chung-Cheng, 1990, An efficient deterministic-probabilistic approach to modeling regional groundwater flow: 2. Application to Owens Valley, California: Water Resources Research, v. 26, no. 7, p. 1569-1581.

Handman, E.H., 1990, Prinicpal results of a ground-water study of Honey Lake Valley, California and Nevada: U.S. Geological Survey Open-File Report 90-155, 2 p.

Handman, E.H., Londquist, C.J., and Maurer, D.K., 1990, Ground-water resources of Honey Lake Valley, Lassen County, California, and Washoe County, Nevada: U.S. Geological Survey WaterResources Investigations Report 90-4050, 112 p.

Harmon, J.G., 1989, Streamflow sediment discharge and streambank erosion in Cache Creek, Yolo County, California, 1953-86: U.S. Geological Survey Water-Resources Investigations Report $88-4188,40 \mathrm{p}$.

Heimes, F.J., Gronberg, J.M., and Carlson, J.R., 1988, Applications of a geographic information system to hydrologic studies in the San Joaquin Valley, Califomia: GIS Symposium, National Academy of Science, Denver, Colorado, September 25-30, 2 p.

Hill, B.R., Hill, J.R., and Nolan, K.M., 1990, Sediment-source data for four basins tributary to Lake Tahoe, Califomia and Nevada, August 1983-June 1988: U.S. Geological Survey Open-File Report 89-618, $42 \mathrm{p}$.

Hill, B.R., and McConaughy, C.E., 1988, Sediment loads in the Ventura River basin, Ventura County, California, 1969-81: U.S. Geological Survey Water-Resources Investigations Report 88-4149, $23 \mathrm{p}$.

Hill, B.R., and Nolan, K.M., 1990, Suspended-sediment factors, Lake Tahoe Basin, California-Nevada: International Mountain Watershed Symposium on Subalpine Processes and Water Quality, Crystal Bay, Nevada, June 8-10, 1988, Proceedings, p. 179-189.

Hoffman, E.B., Bowers, J.C., and Jensen, R.M., 1990, Water resources data--California, water year 1989. Volume 1. Southern Great Basin from Mexican border to Mono Lake basin, and Pacific slope basins from Tijuana River to Santa Maria River: U.S. Geological Survey Water-Data Report CA-89-1, 261 p.

Hollett, K.H., Danskin, W.R., McCaffrey, W.F., and Walti, C.L., 1989, Geology and water resources of Owens Valley, California: U.S. Geological Survey Open-File Report 88-715, 188 p.

Hunter, T.C., Mullen, J.R., and Simpson, R.G., 1988, Water resources data--California, water year 1987. Volume 3. Southern Central Valley basins and the Great Basin from Walker River to Truckee River: U.S. Geological Survey Water-Data Report CA-87-3, 392 p.

Hunter, T.C., Mullen, J.R., Simpson, R.G., and Grillo, D.A., 1988, Water resources data--California, water year 1986. Volume 3. Southern Central Valley basins and the Great Basin from Walker River to Truckee River: U.S. Geological Survey Water-Data Report CA-86-3, 353 p.

Ikehara, M.E., McCaffrey, W.F., and Williams, J.S., 1989, Elevations of bench marks, observation wells, and production wells at Mather Air Force Base, Sacramento, California, 1988: U.S. Geological Survey Open-File Report 88-716, 16 p. 
Iwatsubo, R.T., Sylvester, M.A., and Gloege, I.S., 1988, Water quality of the Lexington Reservoir, Santa Clara County, California, 1978-80: U.S. Geological Survey Water-Resources Investigations Report 87-4253, 64 p.

Johnson, M.J., Houston, E.R., and Neil, J.M., 1988, Test holes for monitoring surface-water/ground-water relations in the Cottonwood Creek area, Shasta and Tehama Counties, California, 1984-85: U.S. Geological Survey Water-Resources Investigations Report 88-4090, 28 p.

Johnson, M.J., Londquist, C.J., Laudon, Julie, and Mitten, H.T., 1988, Geohydrology and mathematical simulation of the Pajaro Valley aquifer system, Santa Cruz and Monterey Counties, California: U.S. Geological Survey Water-Resources Investigations Report 87-4281, 62 p.

Kaehler, C.A., 1990, Methods for selection and hydrologic description of potential landfill sites in southeastern San Diego County, California: U.S. Geological Survey Water-Resources Investigations Report 90-4021, 73 p.

Lamb, C.E., 1988, California ground-water quality, in National Water Summary 1986--Hydrologic events and ground-water quality: U.S. Geological Survey Water-Supply Paper 2325, p. 173-180.

Lamb, C.E., Fogelman, R.P., and Grillo, D.A., 1989, Water resources data--California, water year 1987. Volume 5. Ground-water data for California: U.S. Geological Survey Water-Data Report CA-87-5, $291 \mathrm{p}$.

Lamb, C.E., Fogelman, R.P., and Grillo, D.A., 1989, Water resources data--California, water year 1988. Volume 5. Ground-water data for California: U.S. Geological Survey Water-Data Report CA-88-5, $357 \mathrm{p}$.

Lamb, C.E., Johnson, J.A., Fogelman, R.P., and Grillo, D.A., 1990, Water resources data--California, water year 1989. Volume 5. Ground-water data for California: U.S. Geological Survey Water-Data Report CA-89-5, 385 p.

Lamb, C.E., Keeter, G.L., and Grillo, D.A., 1988, Water resources data--California, water year 1986. Volume 5. Ground-water data for California: U.S. Geological Survey Water-Data Report CA-86-5, 317 p.

Laudon, Julie, and Belitz, Kenneth, 1989, Texture and depositional history of near-surface alluvial deposits in the central part of the western San Joaquin Valley, California: Bulletin of the Association of Engineering Geologists, v. 28, no. 1, p. 73-88.

Markham, K.L., Palmer, J.R., Shelton, W.F., and Trujillo, L.F., 1989, Water resources data--California, water year 1988. Volume 2. Pacific slope basins from Arroyo Grande to Oregon State line except Central Valley: U.S. Geological Survey Water-Data Report CA-88-2, 327 p.

McCaffrey, W.F., Blodgett, J.C., and Thornton, J.L., 1988, Channel morphology of Cottonwood Creek near Cottonwood, California, from 1940 to 1985: U.S. Geological Survey Water-Resources Investigations Report 87-4251, 33 p.

Millard, S.P., and Deverel, S.J., 1988, Nonparametric statistical methods for comparing two sites based on data with multiple nondetect limits: Water Resources Research, v. 24, no. 12, p. 2087-2098.

Mitten, H.T., Lines, G.C., Berenbrock, Charles, and Durbin, T.J., 1988, Water resources of Borrego Valley and vicinity, San Diego County, California: Phase 2--Development of a ground-water flow model: U.S. Geological Survey Water-Resources Investigations Report 87-4199, 27 p. 
Mitten, H.T., and Londquist, C.J., 1990, Documentation of model input and output values for the geohydrology and mathematical simulation of the Pajaro Valley aquifer system, Santa Cruz and Monterey Counties, California: U.S. Geological Survey Open-File Report 90-196, 4 p.

Mullen, J.R., Anderson, S.W., and Hunter T.C., 1989, Water resources data--California, water year 1988. Volume 3. Southern Central Valley basins and the Great Basin from Walker River to Truckee River: U.S. Geological Survey Water-Data Report CA-88-3, 419 p.

Mullen, J.R., Shelton, W.F., and Simpson, R.G., 1988, Water resources data--Califomia, water year 1987. Volume 4. Northern Central Valley basins and the Great Basin from Honey Lake basin to Oregon State line: U.S. Geological Survey Water-Data Report CA-87-4, 276 p.

Mullen, J.R., Shelton, W.F., Simpson, R.G., and Grillo, D.A., 1988, Water resources data--California, water year 1986. Volume 4. Northern Central Valley basins and the Great Basin from Honey Lake Basin to Oregon State line: U.S. Geological Survey Water-Data Report CA-86-4, 286 p.

Neil, J.M., and Beard, Sherrill, 1988, Stratigraphy and mineralogy at the transition between oxidizing and reducing sediments in the San Joaquin Valley, California: Eos, Transactions of the American Geophysical Union, Abstracts, v. 69, no. 44, p. 1181.

Neil, J.M., and Benson, Larry, 1989, Mg variations in calcite from a sediment core from Pyramid Lake, Nevada: Geological Society of America, v. 21, no. 6, p. A259.

Neil, J.M., Lipton, D.S., and Doner, H.E., 1989, Mineralogical changes during sequential extraction procedure for determining the partitioning of selenium in soil of the western San Joaquin Valley, California (abs): Clay Minerals Society, 26th Annual Meeting, Sacramento, California, September 25-28, p. 51.

Nolan, K.M., and Hill, B.R., 1989, Effects of limestone quarrying and cement-plant operations on runoff and sediment yields in the Upper Permanente Creek basin, Santa Clara County, California: U.S. Geological Survey Water-Resources Investigations Report 89-4130, 48 p.

Nolan, K.M., and Hill, B.R., 1989, Storm-runoff generation in the Permanente Creek drainage basin, west central California--an example of flood-wave effects on runoff composition: Journal of Hydrology, no. 113 , p. 343-367.

Nolan, K.M., and Marron, D.C., 1988, Hillslope control on channel response to major storms in two mountainous areas of California: Eos, Transactions of the American Geophysical Union, Abstracts, v. 69, no. 44, p. 1225.

Nolan, K.M., and Marron, D.C., 1988, Stream-channel response to the storm in the Santa Cruz Mountains, in Ellen, S.D., and Wieczorek, G.F., eds., Landslides, floods, and marine effects of the storm of January 3-5, 1982, in the San Francisco Bay region, California: U.S. Geological Survey Professional Paper 1434, p. 245-264.

Oltmann, R.N., Burau, J.R., and Simpson, M.R., 1990, Use of a acoustic Doppler current profiler (ADCP) to measure velocity profiles and discharge: Poster session, Interagency workshop on the Hydrodynamics Study of San Francisco Bay, January, Asilomar, California.

Oltmann, R.N., and Shulters, M.V., 1989, Rainfall and runoff quantity and quality characteristics of four urban-use catchments in Fresno, California, October 1981 to April 1983: U.S. Geological Survey Water-Supply Paper 2335, 114 p. 
Palmer, J.R., Shelton, W.F., Trujillo, L.F., and Markham, K.L., 1990, Water resources data--California, water year 1989. Volume 2. Pacific slope basins from Arroyo Grande to Oregon State line except Central Valley: U.S. Geological Survey Water-Data Report CA-89-2, 309 p.

Phillips, S.P., and Belitz, Kenneth, 1988, Calibration of a texture-based model of a ground-water flow system, western San Joaquin Valley, California: Eos, Transactions of the American Geophysical Union, Abstracts, v. 69, no. 44, p. 1188.

Phillips, S.P., and Belitz, Kenneth, 1990, Calibration of a texture-based model of a ground-water flow system, western San Joaquin Valley, California: U.S. Geological Survey Open-File Report $90-573,30 \mathrm{p}$.

Poland, J.F., and Ireland, R.L., 1988, Land subsidence in the Santa Clara Valley, California, as of 1982: U.S. Geological Survey Professional Paper 497-F, 61 p.

Polinoski, K.G., Hoffman, E.B., Smith, G.B., and Bowers, J.C., 1989, Water resources data--California, water year 1988. Volume 1. Southern Great Basin from Mexican border to Mono Lake basin, and Pacific slope basins from Tijuana River to Santa Maria River: U.S. Geological Survey Water-Data Report CA-88-1, 271 p.

Presser, T.S., Swain, W.C., Tidball, R.R., and Severson, R.C., 1990, Geologic sources, mobilization, and transport of selenium from the California Coast Ranges to the western San Joaquin Valley: A reconnaissance study: U.S. Geological Survey Water-Resources Investigations Report 90-4070, $66 \mathrm{p}$.

Rast, Walter, and Sutton, J.E., 1989, Use of stable carbon and nitrogen isotopes to trace the larval striped bass food chain in the Sacramento-San Joaquin Estuary, California, April to September 1985: U.S. Geological Survey Water-Resources Investigations Report 88-4164, 64 p.

Rockwell, G.L., 1990, Surface-water hydrology of Honey Lake Valley, Lassen County, Califomia, and Washoe County, Nevada: U.S. Geological Survey Open-File Report 90-177, scale 1:100,000, 2 sheets.

Rojstaczer, S.A., Massey, C., Shepherd, L., and Fuller, C.C., 1989, Determining the causes of San Joaquin-Sacramento delta elevation changes (abs.): U.S. Geological Survey Open House, November 19, 1988, 2 p.

Schemel, L.E., Ota, A.Y., Harmon, J.G., Shay, J.M., and Adorador, R.M., 1988, Benthic macrofauna and ancillary data for San Francisco Bay, California, March to November 1987: U.S. Geological Survey Open-File Report 88-192, 73 p.

Schemel, L.E., Ota, A.Y., Harmon, J.G., Shay, J.M., and Adorador, R.M., 1989, Benthic macrofauna and ancillary data for San Francisco Bay, California, January to November 1988: U.S. Geological Survey Open-File Report 89-596, 65 p.

Schroeder, R.A., Palawski, D.U., and Skorupa, J.P., 1988, Reconnaissance investigation of water quality, bottom sediment, and biota associated with drainage in the Tulare Lake Bed area, southern San Joaquin Valley, California, 1986-87: U.S. Geological Survey Water-Resources Investigations Report 88-4001, 86 p.

Schroeder, R.A., Setmire, J.G., and Densmore, J.N., 1989, Controls on drainwater composition in the Imperial Valley, California in Pederson, G.L., and Smith, M.M., compilers, U.S. Geological Survey Second National Symposium on Water Quality: Abstracts of the Technical Sessions, Orlando, Florida, November 12-17, 1989: U.S. Geological Survey Open-File Report 89-409, p. 85. 
Schroeder, R.A., Setmire, J.G., and Wolfe, J.C., 1988, Trace elements and pesticides in Salton Sea area, California: American Society of Civil Engineers, National Irrigation and Drainage Division Conference on Planning Now for Irrigation and Drainage, Lincoln, Nebraska, July 18-21, Proceedings, p. 700-707.

Setmire, J.G., Wolfe, J.C., and Stroud, R.K., 1989, Reconnaissance investigation of water quality, bottom sediment, and biota associated with irrigation drainage in the Salton Sea area, California, 1986-87: U.S. Geological Survey Water-Resources Investigations Report 89-4102, 68 p.

Shelton, L.R., 1989, Improved sampling methods for organic constituents, in Pederson, G.L., and Smith, M.M., compilers, U.S. Geological Survey Second National Symposium on Water Quality: Abstracts of the Technical Sessions, Orlando, Florida, November 17-19: U.S. Geological Survey Open-File Report 89-409, p. 89.

Shelton, L.R., and Miller, L.K., 1988, Water-quality data, San Joaquin Valley, California, March 1985 to March 1987: U.S. Geological Survey Open-File Report 88-479, 210 p.

Shelton, W.F., Anderson, S.W., and Mullen, J.R., 1989, Water resources data--California, water year 1988. Volume 4. Northem Central Valley basins and the Great Basin from Honey Lake to Oregon State line: U.S. Geological Survey Water-Data Report CA-88-4, 289 p.

Shulters, M.V., Oltmann, R.N., and Grabbe, R.R., 1988, Pesticides in rainfall samples collected at Fresno, California, December 1981 through March 1983, in Subitzky, Seymour, ed., Selected papers in the hydrologic sciences, 1987: U.S. Geological Survey Water-Supply Paper 2330, p. 35-40.

Simpson, M.R., and Oltmann, R.N., 1990, An acoustic Doppler discharge-measurement system: American Society of Civil Engineers, Hydraulic Engineering, San Diego, California, Proceedings, p. 903-908.

Smith, L.H., 1990, Sub-tidal salinity variations in San Francisco Bay, California: Eos, Transactions of the American Geophysical Union, Abstracts, v. 71, no. 43, p. 1356-1357.

Smith, P.E., 1990, Practical considerations in modeling the three-dimensional circulation and salinity in San Pablo Bay, California: American Society of Civil Engineers, Hydraulic Engineering, San Diego, California, Proceedings.

Smith, P.E., and Cheng, R.T., 1990, Recent progress on hydrodynamic modeling of San Francisco Bay, California: American Society of Civil Engineers, Estuarine and Coastal Modeling, Newport, Rhode Island, November 15-17, 1989, Proceedings, p. 502-510.

Smith, P.E., and Larock, B.E., 1989, High-resolution two-dimensional advective transport: American Society of Civil Engineers, Hydraulics Division, National Conference on Hydraulic Engineering, 3d, New Orleans, Louisiana, August 14-18, 1989, Proceedings, p. 1005-1010.

Sorenson, S.K., Dileanis, P.D., and Branson, F.A., 1989, Soil water and vegetation responses to precipitation and changes in depth to ground water in Owens Valley, California: U.S. Geological Survey Open-File Report 89-260, 66 p.

Sorenson, S.K., Miller, R.F., Welch, M.R., Groeneveld, D.P., and Branson, F.A., 1989, Estimating soil matric potential in Owens Valley, California: U.S. Geological Survey Water-Supply Paper $2370-\mathrm{C}, 18 \mathrm{p}$.

Steinemann, A.C., 1989, Evaluation of nonpotable ground water in the desert area of southeastern California for powerplant cooling: U.S. Geological Survey Water-Supply Paper 2343, 44 p. 
Steven, M.A., compiler, 1989, Reports for California by the U.S. Geological Survey, Water Resources Division: U.S. Geological Survey Open-File Report 89-29, 244 p.

Swain, W.C., 1988, Characteristics of shallow ground water and subsurface agricultural drainage in the Tulare basin, California: Eos, Transactions of the American Geophysical Union, Abstracts, v. 69, no. 44, p. 1181.

Taylor, M.J., and Yost, B.T., 1990, Description of salinity, temperature, chlorophyll, suspended-sediment, and velocity data, south San Francisco Bay, California, February-April 1987: U.S. Geological Survey Open-File Report 89-619, 28 p.

Templin, W.E., 1988, The California water-use geographic information system, in Waterstone, Marvin, and Burt, R.J., eds., Symposium on water-use data for water resources management, Proceedings: Bethesda, Maryland, American Water Resources Association, Technical Publication Series TPS-88-2, p. 77-84.

Templin, W.E., 1990, Reporting of agricultural water use information for California and the Western States (abs.): American Association for the Advancement of Science, Pacific Division, 71st, v. 9, part 1, p. 54.

Templin, W.E., 1990, California water supply and use, in National Water Summary 1987--Hydrologic events and water supply and use: U.S. Geological Survey Water-Supply Paper 2350, p. 173-182.

Templin, W.E., and Schluter, R.C., 1989, A water-resources data-network evaluation for Monterey County, California, Phase 3: Northern Salinas River drainage basin: U.S. Geological Survey WaterResources Investigations Report 89-4123, 96 p.

Umari, A.M.J., Martin, Peter, and Schroeder, R.A., 1989, Attenuation of nitrogen and fecal coliforms from septic-tank effluent through a thick unsaturated zone, upper Mojave River basin, California, in Pederson, G.L., and Smith, M.M., compilers, U.S. Geological Survey Second National Symposium on Water Quality: Abstracts of the Technical Sessions, Orlando, Florida, November 12-17, 1989: U.S. Geological Survey Open-File Report 89-409, p. 102.

U.S. Geological Survey, 1988, Seawater intrusion in a coastal aquifer: A case study of Pajaro Valley, California: U.S. Geological Survey Yearbook, Fiscal Year 1986, p. 44-45.

Williamson, A.K., Prudic, D.E., and Swain, L.A., 1989, Ground-water flow in the Central Valley, California: U.S. Geological Survey Professional Paper 1401-D, 127 p.

Woolfenden, L.R., 1989, Geohydrology of the Escondido hydrologic subarea, San Diego County, California: U.S. Geological Survey Water-Resources Investigations Report 88-4223, 21 p.

Woolfenden, L.R., and Bright, D.J., 1988, Ground-water conditions in the Anza-Terwilliger area, with emphasis on the Cahuilla Indian Reservation, Riverside County, California: U.S. Geological Survey Water-Resources Investigations Report 88-4029, 79 p.

Woolfenden, L.R., Martin, Peter, and Baharie, Brian, 1988, Aquifer-test evaluation and potential effects of increased ground-water pumpage at the Stovepipe Wells Hotel area, Death Valley National Monument, California: U.S. Geological Survey Water-Resources Investigations Report 87-4270, $26 \mathrm{p}$.

Yates, E.B., 1988, Simulated effects of ground-water management alternatives for the Salinas Valley, California: U.S. Geological Survey Water-Resources Investigations Report 87-4066, 79 p. 
Yates, E.B., 1989, Water quality and supply on Cortina Rancheria, Colusa County, California: U.S. Geological Survey Water-Resources Investigations Report 89-4004, 28 p.

Yates, E.B., Hamlin, S.N., and McCann, L.H., 1990, Geohydrology, water quality, and water budgets of Golden Gate Park and the Lake Merced area in the westem part of San Francisco, California: U.S. Geological Survey Water-Resources Investigations Report 90-4080, 45 p.

Yates, E.B., and Wiese, J.H., 1990, Hydrogeology and water resources of the Los Osos Valley ground-water basin, San Luis Obispo County, California: U.S. Geological Survey WaterResources Investigations Report 88-4081, 74 p.

Yates, M.L., Walker, W.J., and Burau, R.G., 1989, The San Joaquin Valley Drainage Program. A comparison of multiple-laboratory determinations of arsenic, boron, chromium, molybdenum, and selenium in reference materials and other environmental samples (abs.): Quality Assurance Symposium, 1989 Rocky Mountain Conference on Analytical Chemistry, Denver, Colorado, July 30 -August 4 , no. 321.

Yen, Chung-Cheng, and Guymon, G.L., 1990, An efficient deterministic-probabilistic approach to modeling regional groundwater flow: 1. Theory: Water Resources Research, v. 26, no. 7, p. $1559-1567$.

Zell, S.C., Budhraja, M., Riggs, J.L., and Sorenson, S.K., 1990, Monoclonal antibody detection of Giardia lamblia cysts in human stool by direct immunofluorescence: Journal of Wilderness Medicine, v. 1, p. 203-207. 


\section{SOURCES OF WRD PUBLICATIONS AND INFORMATION}

Publications of the U.S. Geological Survey (USGS):--Professional Papers, Water-Supply Papers, Bulletins, Circulars, Water-Resources Investigations Reports, and Open-File Reports are sold by the U.S. Geological Survey, Books and Open-File Reports Section, Federal Center, Box 25425, Denver, CO 80225. Hydrologic Investigations Atlases, Hydrologic Unit Maps, and other maps pertaining to California are sold by the U.S. Geological Survey, Map Distribution Section, Federal Center, Box 25286, Denver, CO 80225 .

U.S. Geological Survey Water-Resources Investigations Reports and Open-File Reports are available for inspection at the California District Office, Water Resources Division, U.S. Geological Survey, Federal Building, Room W-2234, 2800 Cottage Way, Sacramento, CA 95825, and U.S. Geological Survey, 5735 Kearny Villa Road, Suite O, San Diego, CA 92123. Information on their availability may be obtained from the District Chief at the above address.

New reports are announced monthly in "New Publications of the Geological Survey," subscriptions to which are available upon request from the U.S. Geological Survey, 582 National Center, Reston, VA 22092.

Water-Data Program:--Water-data stations at selected locations throughout the Nation are used by the Geological Survey to obtain records on stream discharge (flow) and stage (height), reservoir and lake storage, ground-water levels, well and spring discharge, and the quality of surface and ground water. These data provide a continuing record of the quantity and quality of the Nation's surface- and ground-water resources, and thus provide the hydrologic information needed by Federal, State, and local agencies and the private sector for the development and management of land and water resources. All data collected are stored in the Survey's National Water Data Storage and Retrieval System (WATSTORE) and also are published by water year for each State in a publication series entitled "U.S. Geological Survey Water-Data Report." Information about the Water-Data Program can be obtained from the California District Chief.

NAWDEX:--The National Water Data Exchange was established to assist users of water data to identify, locate, and acquire needed data. It provides a nationwide service for indexing and describing the characteristics of data available from the entire spectrum of data-collection activities throughout the Federal and non-Federal water-data community.

NAWDEX maintains two data bases: (1) a Water-Data Sources Directory and (2) a Master Water-Data Index which identifies and describes available water data. NAWDEX sources can be obtained from the California District Chief. A leaflet explaining NAWDEX services is available from the NAWDEX Program Office, U.S. Geological Survey, 421 National Center, 12201 Sunrise Valley Drive, Reston, VA 22092; phone: (703) 648-5677. 


\section{WHERE TO OBTAIN ADDITIONAL INFORMATION ON}

U.S. GEOLOGICAL SURVEY PROGRAMS

WATER

California District

U.S. Geological Survey

2800 Cottage Way

Room W-2234, Federal Building

Sacramento, CA 95825

Phone: (916) 978-4643

\section{MAPPING}

National Cartographic Information Center U.S. Geological Survey

345 Middlefield Road, MS 532

Menlo Park, CA 94025

Phone: (415) 329-4353

\section{GEOLOGY}

Assistant Chief Geologist

U.S. Geological Survey

345 Middlefield Road, MS 916

Menlo Park, CA 94025

Phone: (415) 329-5101

\section{WHERE TO OBTAIN ADDITIONAL INFORMATION ON}

U.S. GEOLOGICAL SURVEY REPORTS

Earth Science Information Center

U.S. Geological Survey

345 Middlefield Rd., MS 533

Menlo Park, CA 94025

Phone: (415) 329-4390

Phone: (415) 556-5627

Earth Science Information Center

U.S. Geological Survey

7638 Federal Building

300 North Los Angeles St.

Los Angeles, CA 90012

Phone: (213) 894-2850
Earth Science Information Center

U.S. Geological Survey

504 Custom House

555 Battery Street

San Francisco, CA 94111

FOR MAIL ORDERS

\section{BOOKS}

U.S. Geological Survey

Books and Open-File Reports Section

Federal Center, Building 810

Box 25425

Denver, CO 80225

\section{MAPS}

Map Distribution Section

U.S. Geological Survey

Federal Center, Box 25286

Denver, CO 80225 